\title{
Políticas públicas e serviços públicos de gestão e manejo da fauna silvestre nativa resgatada. Estudo de caso: Prefeitura da Cidade de São Paulo
}

\author{
ANGELA MARIA BRANCO
}

Dissertação apresentada ao Programa de PósGraduação da Faculdade de Saúde Pública da Universidade de São Paulo para obtenção do título de Mestre em Saúde Pública

Área de concentração: Saúde Ambiental

Orientadora: Prof ${ }^{\mathrm{a}}$. Dra ${ }^{\mathrm{a}}$. Helena Ribeiro

São Paulo

2008 
É expressamente proibida a comercialização deste documento tanto na sua forma impressa como eletrônica. Sua reprodução total ou parcial é permitida exclusivamente para fins acadêmicos e científicos, desde que na reprodução figure a identificação do autor, título, instituição e ano da dissertação. 
BANCA EXAMINADORA 


\section{DEDICATÓRIA}

Aos meus pais Manoel Branco (in memorian) e Maria do Carmo

À minha filha Maria Fernanda e Alessio V. Gonçalves

À minha família Matheus Tamás Jr. e Cláudia 


\title{
AGRADECIMENTOS
}

\author{
À Professora Doutora Helena Ribeiro \\ pela orientação, confiança e sensibilidade. \\ À Professora Doutora Maria Tereza Pepe Razzolini \\ e \\ Ao Professor Doutor Álvaro Fernando de Almeida \\ pelas contribuições ao trabalho.
}

Na trilha do meu caminho, este trabalho consolida muitos passos.

Muito obrigada a todas as pessoas que o compartilharam comigo!

Optei por não citá-las,

pois, certamente, deixaria de mencionar muitos nomes.

Há, porém, alguns destaques:

Os funcionários da Faculdade de Saúde Pública

pela excelência e dedicação.

A equipe do DEPAVE-3

pelo estímulo e contribuições.

Pedro Luís de Brito Machado e Teresa de Lourdes Cavalheiro

pelo início.

E, principalmente,

Deus

pela constante presença. 
"Enquanto o homem continuar a ser o destruidor dos seres animados dos planos inferiores, não conhecerá a saúde nem a paz. Enquanto os homens massacrarem os animais, eles se matarão uns aos outros. Aquele que semeia a morte e o sofrimento não pode colher a alegria e o amor”.

\section{Pitágoras}

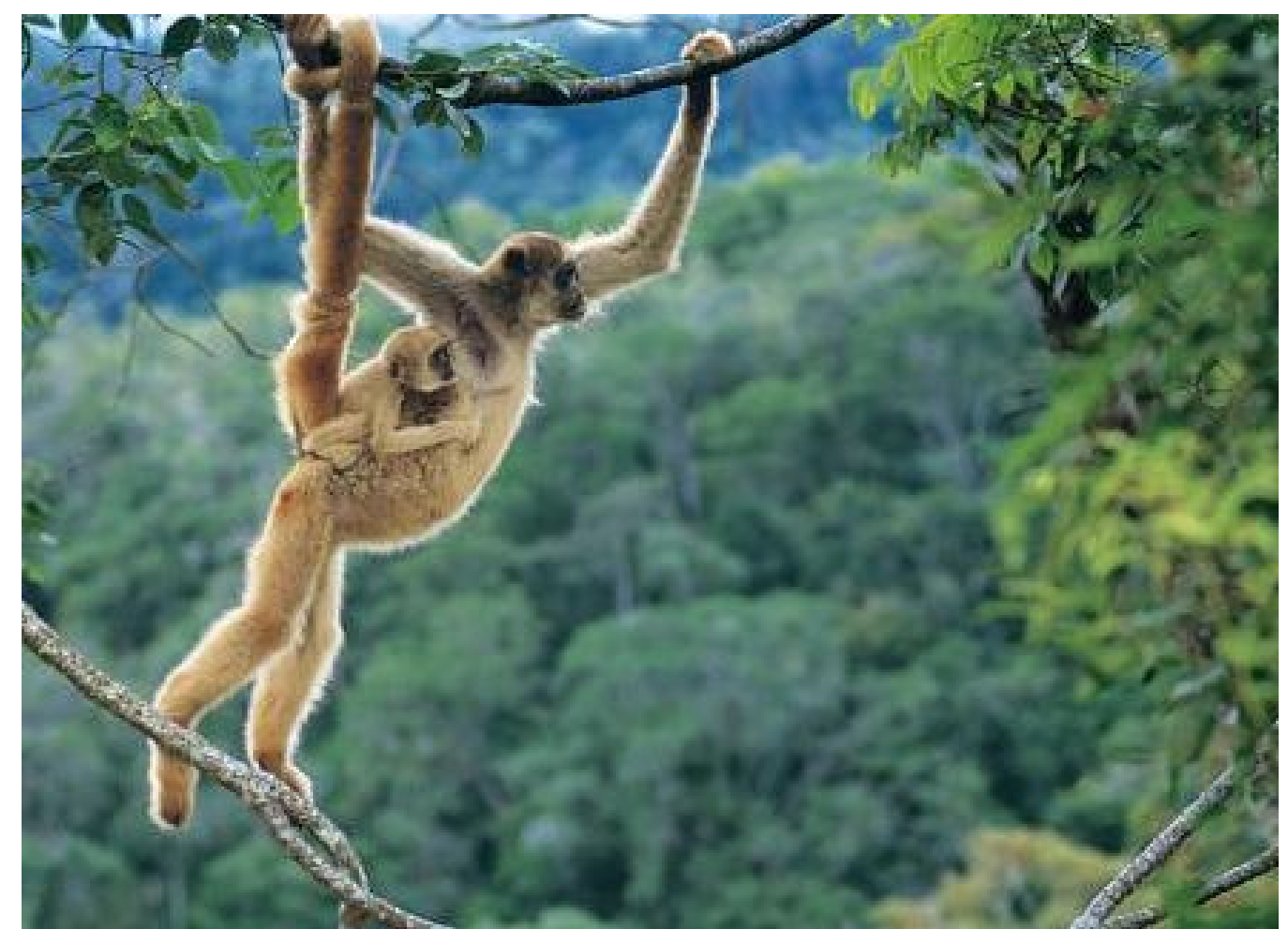

Muriqui (Brachyteles hipoxanthus)

Foto: Luciano Candisani

"Acredito que, ao reintegrarmos um animal ao seu ambiente natural e cuidarmos para que esse se mantenha íntegro, não só demonstramos um profundo respeito à vida e à natureza, como estamos desenvolvendo nossa própria humanidade”. 


\section{RESUMO}

BRANCO, A. M. Políticas públicas e serviços públicos de gestão e manejo da fauna silvestre nativa resgatada. Estudo de caso: Prefeitura da Cidade de São Paulo. [dissertação de mestrado]. São Paulo: Faculdade de Saúde Pública da USP; 2008.

Introdução - O acelerado processo de urbanização provoca sobre os animais silvestres uma forte pressão, que fez com que a Prefeitura de São Paulo criasse por lei, em 1993, um serviço voltado à gestão desse recurso. Objetivo - Analisar as políticas públicas e a gestão da fauna silvestre nativa na Cidade de São Paulo, a fim de verificar se as mesmas trazem contribuições para as áreas de meio ambiente e saúde pública e podem servir de exemplo para outras localidades. Metodologia - Pesquisa do tipo qualitativa descritiva, por meio de um estudo de caso, para uma análise profunda sobre o tema empregando a pesquisa bibliográfica em bases de dados, pesquisa documental e consulta de dados disponíveis no Sistema de Informações da Fauna (SISFAUNA). Resultado - A Cidade de São Paulo conta com um serviço institucionalizado para a gestão da fauna, que fornece subsídios para a elaboração de políticas e estratégias de proteção e preservação ambiental e cumprimento da legislação, contribuindo com a área de educação e de pesquisas voltadas à saúde e bem estar dos animais e da população, dando publicidade dos resultados dos trabalhos. Conclusão - Compete ao Estado, nas suas diferentes esferas, proteger e preservar a fauna silvestre, e que a gestão da fauna deve ser realizada no âmbito dos estados e municípios integrantes do Sistema Nacional do Meio Ambiente (SISNAMA), desde que esses sejam aparelhados com um serviço institucionalizado para esta finalidade, visando garantir o cumprimento da legislação e a tomada de decisões locais, levando em consideração a fauna silvestre de seu território.

Descritores: Saúde Pública; Administração Ambiental; Política Governamental Municipal; Recursos Naturais (Saúde Ambiental); Fauna; Animais Selvagens; Técnicos em Manejo de Animais; Bem-Estar do Animal; Prefeitura da Cidade de São Paulo. 


\begin{abstract}
BRANCO, A. M. Public policies and public services of management and handling of the rescued native wild fauna. Case study: São Paulo City Council. [master thesis]. São Paulo (BR): School of Public Health of the University of São Paulo; 2008.

Introduction - The accelerated urbanization process brings strong pressure to bear on wild animals, which prompted the São Paulo City Council to create by law, in 1993, a service geared towards the management of this resource. Objective - To analyze the public policies and the management of the native wild fauna in the City of São Paulo, in order to verify whether these make contributions to the environmental and public health areas and can serve as an example to other locations. Methodology - Research of the descriptive qualitative type, by means of a case study, for an in-depth analysis of the topic employing bibliographic research in databases, documental research and consultation of data available in the Fauna Information System (SISFAUNA). Result The City of São Paulo has an institutionalized service for fauna management, which furnishes subsidies for the preparation of policies and strategies of environmental protection and preservation and compliance with the legislation, contributing to the area of education and of research focused on the health and well-being of animals and of the population, publicizing the results of the work. Conclusion - It is incumbent upon the State, in its different spheres, to protect and preserve wild fauna, and to ensure fauna management is performed in the sphere of the states and municipalities from the National Environmental System (SISNAMA), providing these have resource to an institutionalized service for this purpose, aiming to guarantee compliance with the legislation and local decision making, taking into consideration the wild fauna from their territory.
\end{abstract}

Descriptors: Public Health; Environmental Administration; Municipal Environmental Policy; Natural Resources (Environmental Health); Fauna; Animals, Wild; Animal Technicians; Animal Welfare; Sao Paulo City Council. 


\section{ÍNDICE}

1. INTRODUÇÃO

2. O PROBLEMA E OBJETIVOS DA PESQUISA …………………………....... 18

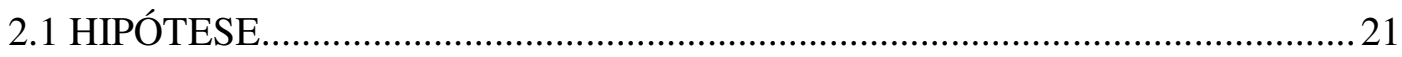

2.2 OBJETIVO GERAL ……………………………………………………. 21

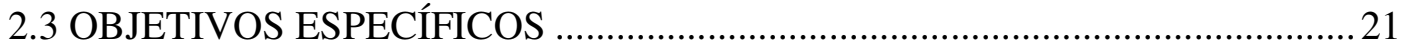

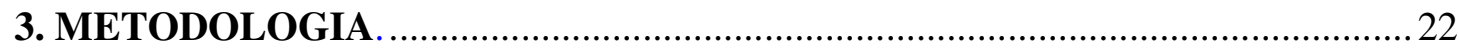

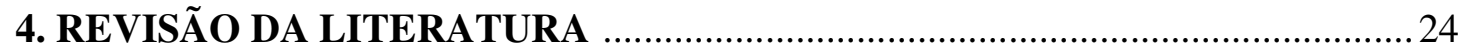

4.1 CONTEXTUALIZAÇÃO DA FAUNA SILVESTRE NO AMBIENTE ............24

4.2 GESTÃO E MANEJO DA FAUNA SILVESTRE NATIVA RESGATADA......39

4.2.1 Centros Internacionais de Recepção de Fauna …………………………......52

4.2.2 Centros Nacionais de Recepção de Fauna ……………………………......58

5. POLÍTICA PÚBLICA BRASILEIRA E A GESTÃo DA FAUNA

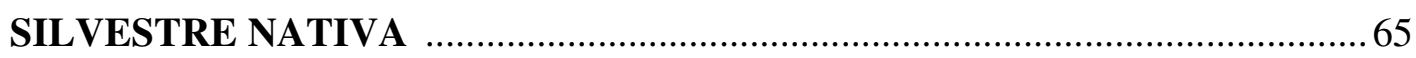

5.1 COMPETÊNCIA DOS MUNICÍPIOS NA GESTÃO AMBIENTAL .................70

6. APRESENTAÇÃO DO CASO ESTUDADO. .........................................................76

6.1 CARACTERIZAÇÃO AMBIENTAL DO MUNICÍPIO DE SÃO PAULO .......76

6.2 CRIAÇÃO DO SERVIÇO MUNICIPAL DE GESTÃO E MANEJO DA

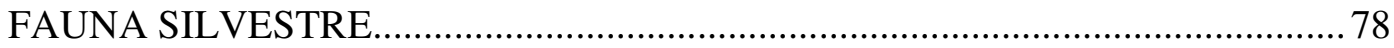

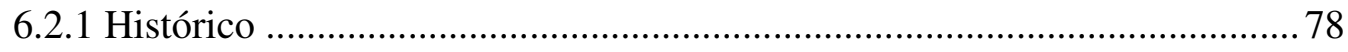

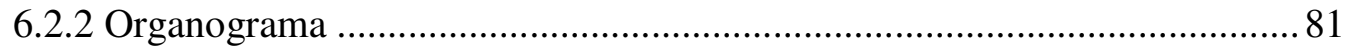

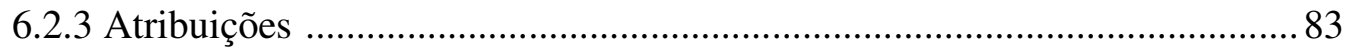

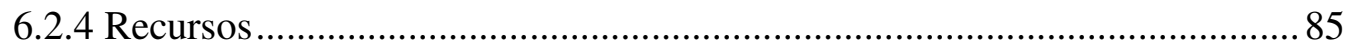

7. DESCRIÇÃO E ANÁLISE DA GESTÃO E DO MANEJO DA FAUNA SILVESTRE NATIVA NA PREFEITURA DE SÃO PAULO ..................................87

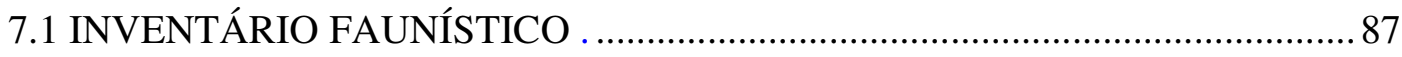

7.2 MANEJO DA FAUNA SILVESTRE NATIVA …………………………........91

7.2.1 Atendimento Médico Veterinário e Biológico dos Animais ........................91 
7.2.2 Pesquisas e Exames Laboratoriais .96

7.2.3 Reabilitação e Destino dos Animais Atendidos .97

7.2.4 Monitoramento. 102

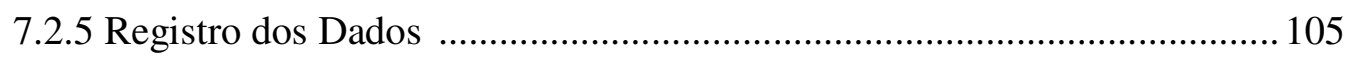

7.3 INDICADORES AMBIENTAIS PARA A FAUNA …...................................... 106

7.4 COMUNICAÇÃO DE RESULTADOS DO TRABALHO .............................. 110

7.4.1 Publicações, Cursos, Visitas Monitoradas ................................................. 110

7.5 EMPREGO DAS INFORMAÇÕES E DADOS ........................................... 112

7.6 CONTRIBUIÇÃO ACADÊMICA E CIENTÍFICA ...................................... 113

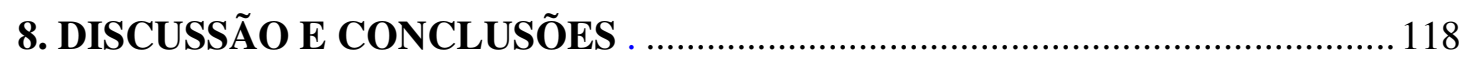

9. RECOMENDAÇÃ

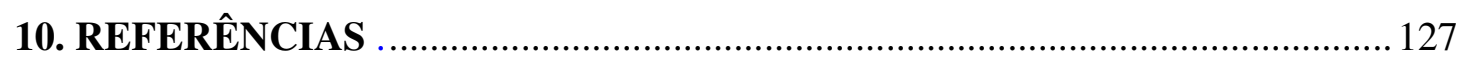

ANEXOS

Anexo 1 -Lei Municipal n 12.055, de 9 de maio de 1996, da Cidade de São Paulo.... 137

Anexo 2 - Decreto Municipal n 37.653 de 25 de setembro de 1998, da Lei Municipal $\mathrm{n}^{\circ} 12.055$, da Cidade de São Paulo

Anexo 3 - Portaria n ${ }^{\circ}$ 008/DEPAVE-G/92, de 14 de abril de 1992 142

Anexo 4 - Carta do PhD Chris Wermer, de 05 de dezembro de 1988 , ao Prefeito Jânio da Silva Quadros

Anexo 5 - Relação das espécies de animais vertebrados levantada no inventário da fauna da Cidade de São Paulo (SÃO PAULO, 2006) . 144 Anexo 6 - Primeira página do Currículo Lattes da autora, retirada da Plataforma Lattes, em cumprimento a Portaria/CPG/03/08 160 


\section{LISTA DE FIGURAS}

Figura 1 - Filhotes de papagaios (Amazona aestiva) apreendidos pela Polícia Federal, 2007 .

Figura 2 - Bugio (Alouatta guariba clamitans) vítima de atropelamento 20

Figura 3 - Número de animais silvestres apreendidos pela Polícia Ambiental do Estado de São Paulo, no período de 1999 a 2005

Figura 4 - Percentual do número de animais destinados pela Polícia Ambiental do

Estado de São Paulo, frente ao local de destino. .35

Figura 5 - Organograma do DEPAVE-3.. 82

Figura 6 - Mapa da Cidade de São Paulo com a localização de áreas protegidas e locais onde foram realizados os estudos de inventário da fauna, no período de 1993 a 2005. São Paulo, 2007..

Figura 7 - Número de animais silvestres nativos que deram entrada no DEPAVE-3, segundo o ano e o motivo da entrada, no período de janeiro de 1992 a dezembro de 2007. São Paulo, 2008

Figura 8 - Percentual do número de animais silvestres nativos que deram saída do DEPAVE-3, segundo o motivo da saída, no período de janeiro de 1992 a dezembro de 2007. São Paulo, 2008

Figura 9 - Soltura de bugios (Alouatta guariba clamitans), após processo de reabilitação

Figura 10 - Fluxograma do manejo de animais silvestres internados no DEPAVE-3.. 104

Figura 11 - Relação das fichas que compõem o prontuário de animais internados....... 105

Figura 12 - Relação dos 83 indicadores ambientais propostos para a Cidade de São

Paulo, com destaque para os indicadores referentes à fauna silvestre. 108 


\section{LISTA DE TABELAS}

Tabela 1 - Número de animais que deram entrada no DEPAVE-3, segundo o ano da entrada e o grupo, no período de janeiro de 1992 a dezembro de 2007. São Paulo, 2008 ..

Tabela 2 - Número de animais silvestres nativos que deram entrada no DEPAVE-3, segundo o ano da entrada e o grupo, no período de janeiro de 1992 a dezembro de 2007. São Paulo, 2008

Tabela 3 - Número exames realizados nos animais internados, segundo o ano e o tipo de exame, no período de 1994 a 1999. São Paulo, 2008

Tabela 4 - Número de animais silvestres nativos que deram saída do DEPAVE-3, segundo o ano e motivo da saída, no período de janeiro de 1992 a dezembro de 2007.

\section{LISTA DE QUADROS}

Quadro 1 - Relação das principais doenças transmitidas por animais silvestres 30

Quadro 2 - Lista dos mamíferos mais apreendidos pela Polícia Ambiental e IBAMA nos estados de São Paulo, Rio de Janeiro, Minas Gerais, Espírito Santo e Bahia, no período de 1999 a 2005

Quadro 3 - Lista das aves mais apreendidas pela Polícia Ambiental e IBAMA, nos estados de São Paulo, Rio de Janeiro, Minas Gerais, Espírito Santo e Bahia, no período de 1999 a 2005

Quadro 4 - Lista dos répteis mais apreendidos pela Polícia Ambienta e IBAMA nos estados de São Paulo, Rio de Janeiro, Minas Gerais, Espírito Santo e Bahia, no período de 1999 a 2005

Quadro 5 - Sistematização sobre as políticas públicas e gestão da fauna silvestre nativa resgatada, em 12 países da Região Neotropical

Quadro 6 - Exemplos de pesquisas e trabalhos científicos que tiveram contribuição de material biológico, decorrente do manejo de animais silvestres, pelo DEPAVE-3 . .... 115 


\section{LISTA DE SIGLAS}

CADES - Conselho Municipal do Meio Ambiente e Desenvolvimento Sustentável CCZ - Centro de Controle de Zoonoses.

CEMAS - Centro de Manejo de Animais Silvestres

CEMAVE - Centro Nacional de Pesquisa para a Conservação das Aves

CETAS - Centro de Triagem de Animais Silvestres

CITES - Convenção sobre o Comércio Internacional das Espécies da Fauna e da Flora Selvagens Ameaçadas de Extinção

CONAMA - Conselho Nacional do Meio Ambiente

CRAS - Centro de Reabilitação de Animais Silvestres

CRAS - Centro de Recuperação de Animais Silvestres

DAEE - Departamento de Águas e Energia Elétrica

DEPAVE - Departamento de Parques e Áreas Verdes

DEPAVE-3 - Divisão Técnica de Medicina Veterinária e Manejo da Fauna Silvestre

FUNASA - Fundação Nacional de Saúde

HSUS - Sociedade Humanitarista dos Estados Unidos

HSI - Sociedade Internacional de Proteção Animal

IBAMA - Instituto Brasileiro do Meio Ambiente e dos Recursos Naturais Renováveis

IBGE - Instituto Brasileiro de Geografia e Estatística

IUCN - União Internacional para a Conservação da Natureza

MMA - Ministério do Meio Ambiente

OMS - Organização Mundial da Saúde

PMSP - Prefeitura da Cidade de São Paulo

RENCTAS - Rede Nacional de Combate ao Tráfico de Animais Silvestres

SISFAUNA - Sistema de Informações da Fauna

SISNAMA - Sistema Nacional do Meio Ambiente

SMA - Secretaria de Estado do Meio Ambiente

SMS - Secretaria Municipal de Saúde

SSO - Secretaria de Serviços e Obras 
SVMA - Secretaria do Verde e do Meio Ambiente

UIPA - União Internacional de Proteção Animal

WCV - Centro de Vida Silvestre da Virgínia

WSPA - Sociedade Mundial de Proteção Animal

WWF - Fundo Mundial para a Natureza 


\section{INTRODUÇÃO}

O Brasil é considerado o País com maior biodiversidade do planeta, com uma exuberante fauna constituída por mais de 100 mil espécies encontradas em florestas, manguezais, cerrados, campos, rios, lagos, entre outros (IBGE, 2001). De acordo com a Conservação Internacional Brasil, no ranking da biodiversidade mundial, o Brasil ocupa o $1^{\circ}$ lugar para mamíferos, $3^{\circ}$ para aves, $5^{\circ}$ para répteis e $2^{\circ}$ para anfíbios ${ }^{1}$.

A Constituição da República Federativa do Brasil incumbe ao Poder Público proteger a fauna e a flora, vedadas, na forma da lei, as práticas que coloquem em risco sua função ecológica, provoquem a extinção de espécies ou submetam os animais à crueldade. Por lei, todos os animais silvestres são considerados propriedade do Estado.

Porém, no Brasil, 639 espécies de animais encontram-se na lista nacional das espécies da fauna brasileira ameaçadas de extinção (MMA, 2007).

O avanço da urbanização sobre os ecossistemas remanescentes exerce uma extrema pressão sobre os animais silvestres, que muitas vezes são as principais vítimas das intervenções provocadas no meio natural, como: desmatamentos, incêndios, obras de infra-estrutura, agro-pecuária e empreendimentos imobiliários, além do interesse econômico pelos animais, suas partes e produtos, que atingem elevados valores no comércio nacional e internacional.

Aos Municípios, também compete preservar a fauna e a flora, inclusive legislando concorrentemente sobre as florestas, caça, pesca, conservação da natureza, proteção do meio ambiente.

São Paulo é exemplo de uma cidade que enfrenta graves problemas de degradação ambiental, conseqüência de uma expansão urbana que desconsiderou, durante toda sua história, a perspectiva de planejamento e, principalmente, os aspectos ambientais nas ações de promoção do desenvolvimento (SVMA, 2004).

Considerando toda problemática ambiental, a Prefeitura da Cidade de São Paulo possui na sua estrutura de governo uma Divisão Técnica voltada ao atendimento de

\footnotetext{
${ }^{1}$ Conservação Internacional Brasil. Disponível em:

<http://www.conservation.org.br/como/index.php?id=11>. Acesso em: 28 abr. 2008.
} 
animais silvestres vitimados na região, além dos apreendidos pelos órgãos de fiscalização.

Este estudo aborda as políticas públicas e a gestão da fauna realizada pela Prefeitura de São Paulo, observando as competências legais, os serviços prestados à população, as atribuições da equipe técnica, os recursos empreendidos para a realização dos trabalhos e seus resultados.

A escolha do tema foi devido ao interesse desta autora pela problemática envolvendo animais silvestres vitimados pela pressão humana, uma vez que, diariamente são resgatados animais envolvidos em acidentes ou apreendidos pelos órgãos de fiscalização, sem que esses problemas cheguem ao conhecimento da população, favorecendo pessoas e instituições que agem de forma ilícita com os animais silvestres.

Outro motivo decorre do fato desta autora ter participado desde início do processo de criação do serviço de fauna, ora como médica veterinária que socorria os animais, ora estimulando a criação de políticas públicas relacionadas à fauna silvestre da Cidade de São Paulo. O serviço esteve sob a coordenação e direção técnica desta autora até o ano de 2003.

O trabalho de pesquisa apresenta-se dividido em capítulos que normalmente compõem uma dissertação, entre outros.

No capítulo da revisão da literatura encontram-se os referenciais teóricos do tema, trazendo contribuições e experiências de diversos autores de países da Região Neotropical.

O capítulo sobre a política pública brasileira e a gestão da fauna silvestre nativa, traz uma síntese da legislação sobre animais silvestres e as responsabilidades dos governos na sua proteção.

O capítulo que trata do estudo de caso discorre sobre a Prefeitura da Cidade de São Paulo, que possui políticas públicas e estrutura institucional para gerir a fauna de seu território, além da importância dessa cidade como disseminadora de práticas bem sucedidas para o Brasil e o mundo. Nesse capítulo são descritos os passos trilhados desde a criação do serviço, até seus produtos e contribuições para a área de meio ambiente e saúde. 
Um capítulo descreve e analisa a gestão da fauna, em especial quanto ao manejo realizado com os animais silvestres nativos resgatados. $\mathrm{O}$ manejo foi destacado da gestão devido as suas peculiaridades.

A apresentação do estudo de caso procurou mostrar os passos dados na direção da criação do serviço, podendo inspirar pessoas ou contribuir para que serviços dessa mesma natureza sejam criados em outras localidades.

Finalmente, o trabalho de pesquisa contém informações e dados relativos ao tema e ao trabalho que é desenvolvido em São Paulo, que reflete o emprego do diagnóstico da fauna para fins de planejamento da cidade, e promoção de projetos voltados à proteção dos animais, educação ambiental, preservação de áreas verdes, pesquisa e saúde. 


\section{O PROBLEMA E OBJETIVOS DA PESQUISA}

A pressão antrópica provoca uma grande alteração do meio que compromete as espécies silvestres, em especial a fauna. No entanto, poucos estudos abordam o papel e a importância da presença de animais silvestres no ambiente urbano, tais como: diversidade faunística; ameaças para a fauna; espécies ameaçadas de extinção; pesquisas de zoonoses que acometem os animais silvestres; indicadores ambientais para a fauna; e as conseqüências das pressões antrópicas sobre os animais no ecossistema urbano.

O Brasil comporta um dos maiores contingentes de espécies silvestres do planeta e situa-se entre os maiores do mundo em biodiversidade. Apesar desta posição privilegiada, o que se tem constatado é o rápido declínio das populações animais e o crescente risco de extinção de espécies em decorrência da redução de hábitats e da crescente ocupação humana e exploração econômica (BRANCO, 2002, p. 237).

No Brasil, 639 espécies animais encontram-se listadas no processo de extinção², sendo que, 627 encontram-se ameaçadas, 2 foram consideradas extintas na natureza e 10 extintas por não existir registro da espécie há mais de 50 anos (MMA, 2007). O Brasil também ocupa o $2^{\circ}$ lugar mundial em número de espécies de aves ameaçadas.

Outros fatores que também contribuem para a extinção de espécies são o tráfico de animais silvestres, a caça predatória e a introdução de espécies exóticas invasoras.

Com a extinção de uma espécie também se perde sua história genética, que não pode ser recriada. As espécies não evoluíram de forma independente e possuem relações intra e interespecíficas com o meio, muitas vezes desconhecidas, que contribuem para a complexidade e equilíbrio dinâmico dos ecossistemas.

No Estado de São Paulo, os principais fatores responsáveis pelo declínio das populações de animais silvestres são decorrentes da urbanização, da agro-pecuária, dos desmatamentos, das queimadas, da contaminação ambiental, apanha e caça.

\footnotetext{
${ }^{2}$ IN MMA n ${ }^{\circ}$ 003, de 28.05.2003 e IN MMA nº 005 Anexo 1, de 26.05.2004 + Portaria ${ }^{\circ} 52$ de 08.11.2005 que acrescenta na lista de 2003 as espécies de peixes e invertebrados aquáticos.
} 
Os órgãos de fiscalização, frente a um delito envolvendo animais silvestres, normalmente autuam o infrator e apreendem os animais (figura 1). Esses necessitam ser rapidamente alojados, alimentados e receberem cuidados médicos veterinário, devido os maus tratos a que foram submetidos.

Figura 1 - Filhotes de papagaios (Amazona aestiva) apreendidos pela Polícia Federal, 2007.

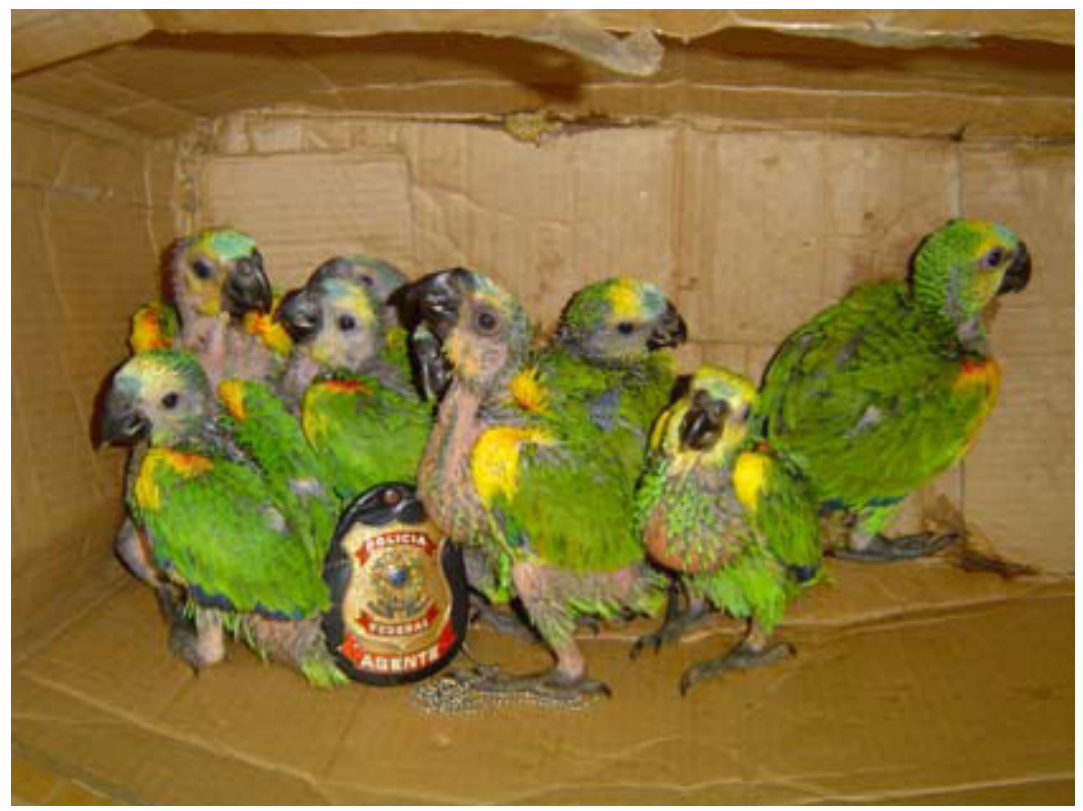

Foto: Polícia Federal

Além das apreensões realizadas pelos fiscais ambientais, também policiais do corpo de bombeiros, agentes de centros de controle de zoonoses ${ }^{3}$ e cidadãos resgatam animais silvestres feridos ou doentes. Esses animais normalmente são vítimas de atropelamentos (figura 2), eletrocussões, incêndios, caçadas, desmatamentos, perda dos pais, ou apenas tidos como invasores de domicílios. Eles normalmente são procedentes da natureza e têm muitas chances de serem recolodos em seu habitat natural, após

\footnotetext{
${ }^{3}$ Zoonose é toda doença ou infecção naturalmente transmissível dos animais vertebrados aos seres humanos. As zoonoses podem ser bacterianas, virais, ou parasitárias, ou ainda podem envolver agentes não convencionais, segundo a Organização Mundial de Saúde (OMS).

Também é definida como enfermidade que se transmite dos animais vertebrados ao homem, e as comum ao homem e aos animais ACHA (1977).
} 
receberem assistência médica veterinária, acompanhamento biológico e nutricional, e passarem por um processo de reabilitação (BRANCO, 2002).

Figura 2 - Bugio (Alouatta guariba clamitans) vítima de atropelamento.

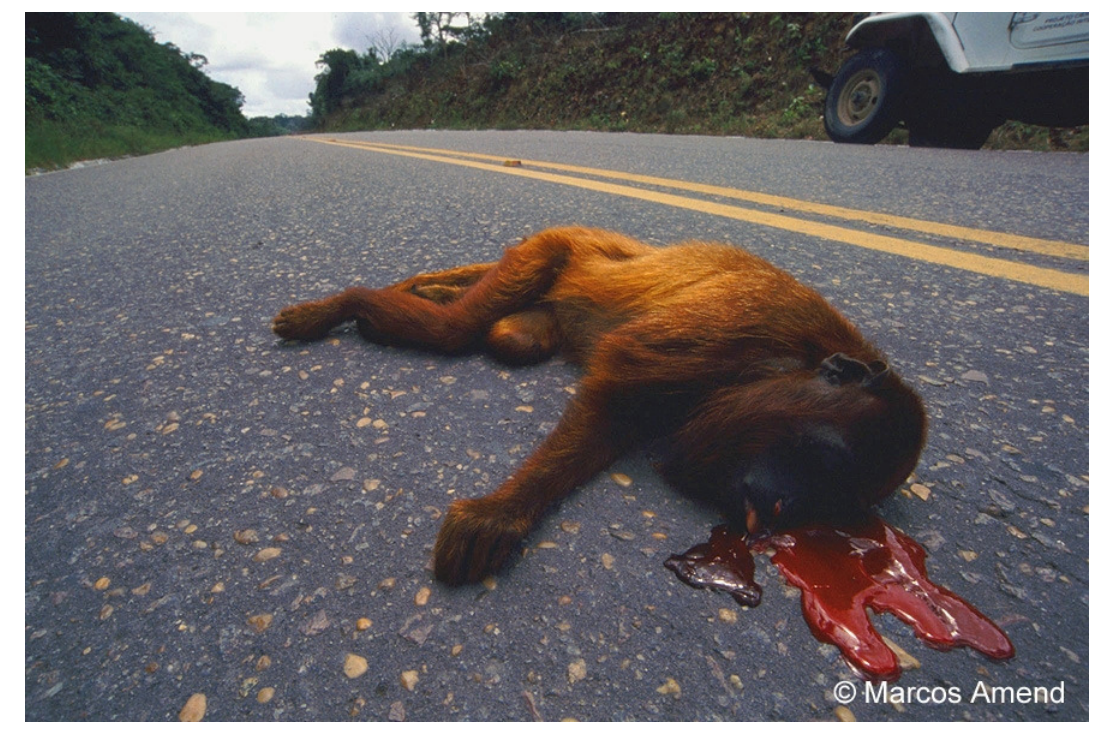

De acordo com a Lei Federal $n^{\circ}$ 9.605, de 12 de fevereiro de 1998, os animais apreendidos serão libertados em seu hábitat ou entregues a jardins zoológicos, fundações ou entidades assemelhadas, desde que fiquem sob a responsabilidade de técnicos habilitados.

Internacionalmente, as instituições que recebem animais vitimados com a finalidade de libertá-los são conhecidas como "centros de resgate de fauna" e a maioria é gerida por entidades não governamentais.

Na cidade de São Paulo, a Prefeitura conta em sua estrutura de governo com uma unidade técnica, criada legalmente, com atribuições precípuas voltadas ao atendimento de animais silvestres resgatados provenientes da região, visando a sua reintegração na natureza. Trata-se da Divisão Técnica de Medicina Veterinária e Manejo da Fauna Silvestre (DEPAVE-3), pertencente à Secretaria Municipal do Verde e do Meio Ambiente (SVMA). 


\subsection{HIPÓTESE}

Ao iniciar este estudo, foi formulada a seguinte hipótese:

O Estado, nas suas diferentes esferas de governo, deve ser aparelhado para fazer a gestão e o manejo da fauna silvestre nativa, em seu território.

\subsection{OBJETIVO GERAL}

Avaliar a política pública e a gestão da fauna silvestre nativa, adotada pela Prefeitura de São Paulo, a fim de verificar se as mesmas podem se prestar como modelo descentralizado para outros órgãos ambientais.

\subsection{OBJETIVOS ESPECÍFICOS}

- Analisar a política pública voltada para a fauna silvestre nativa;

- Descrever e analisar a gestão e o manejo dos animais silvestres realizados pela Prefeitura de São Paulo;

- Coletar e analisar dados referentes à gestão e ao manejo dos animais silvestres pela Prefeitura de São Paulo;

- Apresentar dados relativos à gestão da fauna silvestre da Cidade de São Paulo, decorrentes dos trabalhos realizados pelo DEPAVE-3, no período de 1992 a 2007.

- Descrever os indicadores ambientais propostos para a fauna silvestre na Cidade de São Paulo.

- Avaliar se a gestão da fauna silvestre, realizada pela Prefeitura de São Paulo, traz contribuições para as áreas de meio ambiente e saúde pública. 


\section{METODOLOGIA}

De acordo com GIL (2002), as pesquisas podem ser classificadas em três diferentes grupos: exploratórias, explicativas e descritivas.

Este trabalho de pesquisa é do tipo descritivo, considerando que tem como objetivo principal a avaliação de um serviço, através da descrição e análise da forma como ele foi instituído e da sua operação. Trata-se de uma pesquisa qualitativa, realizada a partir de um estudo de caso, envolvendo a Prefeitura da Cidade de São Paulo.

A escolha de um estudo de caso foi devido ao interesse na realização de um estudo profundo sobre o tema escolhido, de maneira a permitir o seu amplo detalhamento, uma vez que este é o método de pesquisa adotado para a investigação de fenômenos das diversas áreas do conhecimento (GIL, 2002).

A pesquisa foi desenvolvida em três fases:

A primeira fase, de revisão bibliográfica sobre o tema, teve um caráter descritivo, baseada em informações disponíveis na literatura nacional e internacional, onde foram utilizados livros, artigos de revistas, teses, dissertações e sites na internet.

As pesquisas bibliográficas foram realizadas em bases de dados como: Dedalus, Lilacs, Solaris, SciELO, Unibibli e em sites de busca como Google Acadêmico, empregando os descritores e as seguintes palavras chave: política pública fauna; política pública animais; lei fauna; gestão fauna; gestão animais; manejo fauna silvestre; manejo animais selvagens; fauna silvestre; animais silvestres; resgate fauna; triagem animais; reabilitação fauna; reabilitação animais; doença silvestre; tráfico animais; cetas; cras; cemas; depave fauna; divisão fauna; inventário fauna são paulo; indicadores fauna; conservação fauna. Muitas destas também foram pesquisadas nos idiomas inglês e espanhol.

Durante esta fase da pesquisa, foram poucos os estudos que contribuíram para redação da dissertação, pois na sua maioria, não trazia elementos referentes às especificidades do tema proposto, e quando existentes, normalmente concentravam-se em um determinado período do tempo, mais especificamente no final da década de 1990, quando a questão sobre fauna nativa resgatada foi foco de discussões internacionais. 
A segunda fase, abordando principalmente o conteúdo tratado no estudo de caso, foi realizada em documentos institucionais como relatórios de atividades anuais; diários oficiais e publicações institucionais. Segundo GIL (2002) a pesquisa documental é muito semelhante à pesquisa bibliográfica, porém tem o objetivo específico de consultar arquivos públicos e particulares, além do que foi produzido e divulgado pela imprensa. Também foram consultadas diferentes unidades da SVMA, que disponibilizaram informações e dados por elas gerenciados.

$\mathrm{Na}$ terceira fase, de apresentação de dados, a pesquisa foi realizada no Sistema de Informações da Fauna (SISFAUNA) empregado pelo DEPAVE-3. Esse sistema documenta e armazena dados relativos aos animais recebidos para atendimento, e nele, encontram-se os registros da ficha de retenção do animal contendo as informações sobre a sua entrada e destinação.

Os dados qualitativos e quantitativos referentes às diferentes espécies animais atendidas durante o período de 1992 a 2007, encontram-se apresentados na forma de tabelas e gráficos.

Também foram consolidados alguns dados referentes aos estudos de inventário faunístico, realizado no âmbito da Cidade de São Paulo, dando-se destaque à diversidade de mamíferos, aves, répteis, anfíbios e peixes, com o status do grau de ameaça de extinção, de acordo com a lista das espécies ameaçadas do Estado de São Paulo. Os locais onde os estudos foram realizados encontram-se pontuados em um mapa ilustrativo da cidade de São Paulo.

Finalmente, foram apresentadas algumas informações decorrentes da gestão pública da fauna silvestre, como: indicadores para a fauna, pesquisas, publicações e contribuições para a área acadêmica. 


\section{REVISÃO DA LITERATURA}

\subsection{CONTEXTUALIZAÇÃO DA FAUNA SILVESTRE NO AMBIENTE}

"A biosfera, em seu aspecto planetário, pode ser entendida como conjunto de bem sucedidas comunidades, organizadas em ecossistemas naturais e que, assim, se mantém ao longo do tempo" (FORATTINI, 2004, p. 248).

Segundo ODUM (1988), os organismos vivos e o seu ambiente não-vivo estão inseparavelmente inter-relacionados e interagem entre si. Chamamos ecossistema qualquer unidade que abranja todos os organismos que funcionam em conjunto, ou seja, a comunidade biótica numa dada área, interagindo com o ambiente físico de tal forma que um fluxo de energia produza estruturas bióticas claramente definidas e uma ciclagem de materiais entre as partes vivas e não-vivas.

O ecossistema é a unidade funcional básica na ecologia, pois inclui tanto os organismos quanto o ambiente abiótico; cada um destes fatores influencia as propriedades do outro e cada um é necessário para a manutenção da vida, como a conhecemos. "Este nível de organização deve ser nossa primeira preocupação se quisermos que a nossa sociedade inicie a implementação de soluções holísticas para os problemas que estão aparecendo agora ao nível do bioma e da biosfera" (ODUM, 1988, p. 9).

Os Biomas representam um grande biossistema regional ou subcontinental, normalmente caracterizado por um tipo principal de vegetação ou outro aspecto identificador da paisagem (ODUM, 1988), como por exemplo, o Bioma da Mata Atlântica, característico no Município de São Paulo, nas regiões Norte e Sul, fortemente pressionados pelo ambiente urbano.

De acordo com SOBRAL (1996), o ambiente urbano não é o mesmo que o ecossistema natural, onde há uma interação entre seus diversos elementos como a temperatura, as águas , a vegetação, o tipo de solo, entre outros. "Nas cidades o homem e suas construções mudaram drasticamente o funcionamento desses elementos, rompendo o equilíbrio que antes havia. As cidades são as maiores propulsoras dos 
impactos que o homem causa na natureza e onde mais se alteraram os recursos naturais: terra, água, ar e organismos" ( p. 11).

O Instituto Nacional de Estudos Demográficos (INED), publicou em sua revista "Population et Sociétés", que o índice de urbanização do mundo ultrapassou os $50 \%$ em 2007, a partir de dados fornecidos pela Organização das Nações Unidas (ONU), e que agora, a maior parte da população mundial vive nas cidades (FOLHA ON LINE, 2007).

Segundo o Instituto Brasileiro de Geografia e Estatística (IBGE, 2000), no Brasil, $81,2 \%$ da população brasileira vive nas áreas urbanas. A pesquisa aponta que no período de 1940 a 2000, a população brasileira cresceu quatro vezes, atingindo 169,8 milhões de pessoas.

Isso significa que, para os assentamentos humanos e desenvolvimento de suas atividades, o meio natural passa a dar lugar ao urbano, que desencadeia um processo de destruição do ecossistema natural.

A redução do hábitat natural tem sido apontada como uma das principais causas da extinção de espécies, e no Brasil, ecossistemas como a Floresta Amazônica e a Mata Atlântica apresentam os maiores índices de devastação. A Mata Atlântica atualmente possui apenas $7 \%$ da sua coberta original devido à urbanização, agropecuária, queimadas, extrativismo, desmatamento, entre outros fatores.

Com relação à presença e diversificação da fauna silvestre em uma determinada localidade, essas dependem de fatores abióticos e bióticos. Os abióticos são aqueles físicos ou químicos que atuam sobre o meio ambiente, como: temperatura, insolação, chuva, água de superfície e subterrânea, tipo de solo. Dentre os fatores bióticos, existem aqueles de potencial biótico que criam condições para o aumento da população, como: taxa de reprodução, habilidade de migração ou de invasão de hábitat, existência de mecanismos eficientes de defesa, capacidade de dispersar sementes; bem como aqueles de resistência ambiental que acarretam diminuição da população, como: falta de hábitat adequado, falta de alimentos ou água, existência de doenças, parasitas, existência descontrolada de predadores, existência de poluentes e outros produtos prejudiciais ao organismo, entre outros (MOURA, 2004). 
Em sistemas naturais habitados somente por animais, quando existe um excesso de consumo de recursos locais, o que ocorre é um reequacionamento da demanda, com conseqüente diminuição da população, enquanto que, nas comunidades humanas a situação pode ser mitigada, principalmente, com a importação de recursos de outros espaços. Nas cidades, parte das preocupações ambientais é transferida para outros locais por meio da importação de recursos naturais (TAYRA e RIBEIRO, 2006).

As cidades são consideradas como sistemas ecológicos complexos e dinâmicos que merecem atenção e cuidados. As espécies, nelas presentes, tanto podem trazer importância econômica, paisagística e afetiva, quanto podem trazer problemas, como a presença de animais sinantrópicos indesejáveis e o risco de doenças, exigindo cuidados para garantir a convivência harmônica que possa traduzir em qualidade de vida para os seus habitantes (SVMA, 2007).

Segundo CLARK JR (1999), à medida que os assentamentos humanos têm invadido os hábitats silvestres, tem aumentado de forma dramática o contato entre os seres humanos e os animais silvestres, e os humanos têm exercido um forte impacto sobre a vida silvestre nunca experimentado em nenhum período da história humana.

Os impactos indiretos são na maioria das vezes os mais devastadores. Estes incluem a destruição de hábitat, o uso de pesticidas e a introdução de espécies exóticas e domésticas nos ecossistemas naturais. A retirada de animais da natureza, principalmente das espécies ameaçadas para atender o comércio ilegal, causa um impacto direto sobre as populações. "Nunca vamos poder determinar com precisão a mortalidade causada pela ação do homem" (a tradução é nossa) (CLARK JR, 1999, p. 94).

Segundo a União Internacional para a Conservação da Natureza (IUCN) ${ }^{4}$, a vida na terra está desaparecendo rapidamente e continuará assim a menos que medidas urgentes sejam adotadas. Atualmente, há 41.415 espécies na lista vermelha da IUCN, e 16.306 delas encontram-se ameaçados de extinção. O número total de espécies extintas na natureza alcançou 785, sendo que, 65 delas são encontradas somente em cativeiro.

\footnotetext{
${ }^{4}$ IUCN - International Union for Conservation of Nature. Disponível em:

<http://cms.iucn.org/about/work/programmes/species/red_list/index.cfm>. Acesso em: 21 abr. 2008.
} 
A lista oficial brasileira das espécies ameaçadas de extinção, segundo MMA (2007), registra 395 espécies entre mamíferos, aves, répteis, anfíbios, insetos e invertebrados terrestres, além de 232 espécies de peixes e invertebrados aquáticos.

A Lei Federal n ${ }^{\circ} 5.197$ de 1967, em seu artigo $2^{\circ}$, proíbe a caça profissional no Brasil, porém, tanto a caça como a captura de animais são praticadas ilegalmente em todo o território brasileiro para o consumo e venda de seus produtos e sub-produtos, e também, para abastecerem o comércio ilícito de animais silvestres.

Para HOYT (1999, p 55), “Os animais silvestres estão sendo capturados e explorados com mais freqüência para obtenção de ganhos financeiros e prazer, na maioria das vezes ilegalmente e quase sempre de forma indevida" (a tradução é nossa).

Segundo Nilsson e Hemley, citados por DREWS (1999), "no mundo estima-se que anualmente cerca de 30.000 primatas, 2 a 5 milhões de aves, 2 a 3 milhões de répteis e 500 a 600 milhões de peixes ornamentais sejam comercializados para atender a demanda de animais vivos como mascotes em domicílios, zoológicos e animais de laboratório" (a tradução é nossa), sem incluir a grande proporção de animais que morrem antes de sair para o tráfico internacional (p. 17).

De acordo com WWF-BRASIL (1995), "depois do tráfico de drogas e de armas, o contrabando de animais silvestres representa o terceiro maior negócio ilícito praticado no mundo" (p. 11). O Brasil é um dos principais países que comercializam e exportam espécies da fauna de forma ilegal, sendo que, as condições econômicas da população, a riqueza da biodiversidade e a ineficiência dos órgãos governamentais de controle são fatores que reforçam essa situação. O tráfico também é avaliado como o segundo fator responsável pela redução populacional de várias espécies nativas, depois da redução de hábitat pelo desmatamento.

A WWF BRASIL (1995) aponta que cerca de 12 milhões de animais silvestres desaparecem da natureza por ano no Brasil, de acordo com a Moção do Conselho Nacional do Meio Ambiente - CONAMA 16/91. O comércio ilegal chega a movimentar cerca de 10 bilhões de dólares por ano em todo o mundo, no qual o Brasil, segundo militantes ambientalistas, teria participação de 10 a $15 \%$ desse mercado. 
Após alguns anos, a Rede Nacional de Combate ao Tráfico de Animais Silvestres (RENCTAS), aponta que essa atividade ilegal estaria retirando cerca de 38 milhões de animais por ano do País, a partir de dados oficiais sobre as apreensões efetuadas pelos órgãos de fiscalização e projeções estatísticas (RENCTAS, 2001).

OLIVEIRA (2000) afirma que "Alguns traficantes tiram dessa atividade uma renda tão lucrativa que chegam a manter pistas de pouso clandestinas em fazendas para movimentar o tráfico" (p. 15).

Além de todos os prejuízos decorrentes do comércio ilegal para o meio ambiente e economia do País, os riscos à saúde pública têm sido aparentemente ignorados pelas autoridades governamentais, uma vez que, animais silvestres retirados da natureza e confinados em residências podem transmitir dezenas de doenças a outros animais e zoonoses aos humanos, bem como serem acometidos por elas.

De acordo com PMSP (2008), devemos considerar que, historicamente, as ações de saúde pública com intervenções no meio ambiente estavam relacionadas à qualidade da água de consumo e ao controle de:

- Vetores - como os insetos transmissores da dengue;

- Reservatórios ou hospedeiros da raiva - como os morcegos e cães;

- Animais peçonhentos - como as cobras e aranhas.

Ampliando as ações e com o intuito de garantir e promover a saúde humana nos mais diversos ambientes aonde ocorre a presença do homem, surge o conceito de vigilância ambiental em saúde, que de acordo com a Fundação Nacional de Saúde (FUNASA $)^{5}$, configura como "um conjunto de ações que proporcionam o conhecimento e a detecção de qualquer mudança nos fatores determinantes e condicionantes do meio ambiente que interferem na saúde humana, com a finalidade de recomendar e adotar as medidas de prevenção e controle dos fatores de riscos e das doenças ou agravos relacionados à variável ambiental".

\footnotetext{
${ }^{5}$ FUNASA - Ministério da Saúde. IN no 1 de 25/09/2001 que trata da Vigilância Ambiental em Saúde. Disponível em: <http://www.funasa.gov.br/Web\%20Funasa/legis/pdfs/ins/in_001_2001.pdf>. Acesso em: 15 jun. 2008.
} 
Como conseqüência, foi criado o Sistema Nacional de Vigilância em Saúde (SINVAS) que também trata das competências dos municípios na área de vigilância ambiental, e tem como objetivo identificar os riscos e divulgar as informações referentes aos fatores ambientais condicionantes e determinantes das doenças e outros agravos à saúde.

Como pode ser observada, a questão animal no meio urbano está associada à saúde ambiental e, atualmente, merece destaque entre os fatores ambientais de risco as doenças transmissíveis pelos animais silvestres, face ao crescimento das cidades em direção às áreas de matas.

NOGUEIRA-NETO (1973) já alertava sobre o risco de transmissão de enfermidades entre os animais silvestres e o homem, e vice-versa. Enquanto que algumas doenças, como a febre amarela, estão restritas a determinadas famílias zoológicas como os primatas; outras podem afetar inúmeras espécies de animais, como a toxoplasmose, causada por um protozoário que atinge aves, roedores, carnívoros, ruminantes, suínos, ocasionando perturbações nervosas, digestivas e respiratórias.

Alertava também para o risco da ornitose, doença que pode ser mortal e acometer pessoas que lidam com aves, chamando a atenção para os sintomas que normalmente são confundidos com a gripe, mononucleose, meningite e até febre tifóide.

A raiva foi outra patologia destacada pelo autor, que transmitida por qualquer espécie de mamífero, pode permanecer por vários anos incubada em algumas espécies como os morcegos, primatas e raposas, sem apresentar sintomatologia.

Segundo a RENCTAS (2001), animais silvestres podem transmitir zoonoses, e entre as mais comuns estão:

Primatas - febre amarela, capilariose, equinostomíase, esofagostomíase, febre de Mayaro, hepatite A, herpes simples, malária, tuberculose, shigelose, salmonelose, toxoplasmose, raiva, entre outras;

Quelônios $^{6}$ - doença enterobacteriana por arizona e salmonelose;

Psitacídeos $^{7}$ - toxoplasmose, psitacose.

\footnotetext{
${ }^{6}$ Quelônios como: jabutis, cágados e tartarugas.

${ }^{7}$ Psitacídeos como: papagaios, araras e periquitos.
} 
Ainda, segundo NOGUEIRA-NETO (1973), muitas das doenças são letais se não tratadas adequadamente.

SILVA (2008) compila as principais zoonoses e doenças emergentes parasitárias e infecciosas (quadro 1) que podem ser transmitidas pelos animais silvestres:

Quadro 1 - Relação das principais doenças transmitidas por animais silvestres.

\begin{tabular}{|c|c|c|}
\hline $\begin{array}{c}\text { Doença e } \\
\text { Agente Etiológico }\end{array}$ & $\begin{array}{l}\text { Principais Fontes } \\
\text { de Infecção e } \\
\text { Reservatório }\end{array}$ & Vias de Transmissão \\
\hline $\begin{array}{l}\text { Amebiose } \\
\text { Entamoeba histolytica }\end{array}$ & Mar & $\begin{array}{l}\text { Ingestão de água e alimentos } \\
\text { contaminados com cistos. }\end{array}$ \\
\hline $\begin{array}{l}\text { Aspergilose } \\
\text { Aspergillus flavus }\end{array}$ & Aves & $\begin{array}{l}\text { Ingestão de conídias de solo } \\
\text { contaminado. }\end{array}$ \\
\hline $\begin{array}{l}\text { Brucelose } \\
\text { Brucella abortus, } \\
\text { Brucella suis, } \\
\text { Brucella ovis } \\
\text { Brucella canis }\end{array}$ & $\begin{array}{l}\text { Ungulados } \\
\text { Carnívoros }\end{array}$ & $\begin{array}{l}\text { Ingestão } \\
\text { contaminados com brucélas } \\
\text { através de fetos abortados, } \\
\text { placenta e líquidos uterinos. } \\
\text { Exposição por meio das } \\
\text { mucosas genital e conjuntival, } \\
\text { da pele e das vias respiratórias. }\end{array}$ \\
\hline $\begin{array}{l}\text { Campilobacteriose } \\
\text { Campilobacter } \mathrm{sp}\end{array}$ & $\begin{array}{l}\text { Animais e seus } \\
\text { subprodutos. }\end{array}$ & $\begin{array}{l}\text { Via fecal-oral, direta ou indireta } \\
\text { Ingestão de produtos de origem } \\
\text { animal contaminados com fezes } \\
\text { infectadas. }\end{array}$ \\
\hline $\begin{array}{l}\text { Clamidiose } \\
\text { Chlamydophyla psittaci }\end{array}$ & $\begin{array}{l}\text { Psitacídeos } \\
\text { Columbiformes }\end{array}$ & $\begin{array}{l}\text { Inalação de aerossóis em } \\
\text { ambientes contaminados ou pela } \\
\text { via digestiva. }\end{array}$ \\
\hline $\begin{array}{l}\text { Complexo hidatidose- } \\
\text { equinococose } \\
\text { Equinococcus granulosus }\end{array}$ & $\begin{array}{l}\text { Raposas } \\
\text { Cervídeos } \\
\text { (ciclo silvestre) }\end{array}$ & $\begin{array}{lrr}\text { Ingestão } & \text { de } & \text { vísceras } \\
\text { contaminadas } & \text { com } & \text { cistos } \\
\text { hidáticos. } & & \\
\end{array}$ \\
\hline
\end{tabular}




\begin{tabular}{|c|c|c|}
\hline $\begin{array}{l}\text { Criptosporidiose } \\
\text { Cryptosporidium spp }\end{array}$ & Mamíferos & $\begin{array}{l}\text { Ingestão de água e alimentos } \\
\text { contaminados com oocistos. }\end{array}$ \\
\hline $\begin{array}{l}\text { Dirofilariose } \\
\text { Dirofilaria immitis }\end{array}$ & $\begin{array}{l}\text { Canídeos } \\
\text { Procionídeos }\end{array}$ & $\begin{array}{l}\text { Através do repasto sangüíneo } \\
\text { (inoculação de microfilárias) } \\
\text { pelos vetores biológicos } \\
\text { mosquitos (Culex, Aedes, } \\
\text { Anopheles, outros). }\end{array}$ \\
\hline $\begin{array}{l}\text { Doença de Chagas } \\
\text { Trypanosoma cruzi }\end{array}$ & $\begin{array}{l}\text { Mais de } 200 \\
\text { espécies de } \\
\text { mamíferos, } \\
\text { principalmente o } \\
\text { gambá (Didelphis } \\
\text { sp). }\end{array}$ & $\begin{array}{l}\text { Contato com as fezes dos } \\
\text { vetores biológicos (hemípteros) } \\
\text { principalmente dos gêneros } \\
\text { Triatoma, Panstrongylus e } \\
\text { Rhodnius } \\
\text { tripomastigotas. }\end{array}$ \\
\hline $\begin{array}{l}\text { Fasciolose } \\
\text { Fasciola hepatica }\end{array}$ & Herbívoros & $\begin{array}{l}\text { Ingestão de água e vegetação } \\
\text { contaminadas } \\
\text { metacercárias encistadas. }\end{array}$ \\
\hline $\begin{array}{l}\text { Febre Maculosa } \\
\text { Rickettsia rickettsii }\end{array}$ & $\begin{array}{l}\text { Capivaras } \\
\text { (principal } \\
\text { reservatório } \\
\text { suspeito). }\end{array}$ & $\begin{array}{ll}\text { Através de picadas } & \text { de } \\
\text { carrapatos, possivelmente } & \text { do } \\
\text { gênero Amblyomma spp. }\end{array}$ \\
\hline $\begin{array}{l}\text { Giardíase } \\
\text { Giardia intestinalis }\end{array}$ & Carnívoros & $\begin{array}{l}\text { Ingestão de água e alimentos } \\
\text { contaminados com cistos. }\end{array}$ \\
\hline $\begin{array}{l}\text { Histoplasmose } \\
\text { Histoplasma capsulatum }\end{array}$ & $\begin{array}{l}\text { Morcegos } \\
\text { Aves }\end{array}$ & $\begin{array}{l}\text { Inalação de esporos dos fungos } \\
\text { em ambientes fechados, } \\
\text { principalmente cavernas. }\end{array}$ \\
\hline $\begin{array}{l}\text { Larva migrans cutânea } \\
\text { Ancylostoma braziliensis }\end{array}$ & Canídeos & $\begin{array}{l}\text { Solo contaminado com ovos do } \\
\text { parasita e através da pele } \\
\text { (larvas). }\end{array}$ \\
\hline
\end{tabular}




\begin{tabular}{|c|c|c|}
\hline $\begin{array}{l}\text { Larva migrans visceral } \\
\text { Toxocara canis }\end{array}$ & Canídeos & $\begin{array}{l}\text { Fecal-oral (solo contaminado } \\
\text { com ovos do parasita). }\end{array}$ \\
\hline $\begin{array}{l}\text { Leishmaniose } \\
\text { tegumentar } \\
\text { Leishmania braziliensis }\end{array}$ & $\begin{array}{l}\text { Roedores } \\
\text { Preguiça } \\
\text { Tamanduá } \\
\text { Canídeos } \\
\text { Eqüídeos }\end{array}$ & $\begin{array}{l}\text { Vetores biológicos } \\
\text { flebotomíneos Lutzomyia spp } \\
\text { (mosquito-palha). }\end{array}$ \\
\hline $\begin{array}{l}\text { Leishmaniose visceral } \\
\text { Leishmania chagasi }\end{array}$ & Canídeos & $\begin{array}{l}\text { Vetores biológicos } \\
\text { flebotomíneos Lutzomyia spp } \\
\text { (mosquito-palha). }\end{array}$ \\
\hline $\begin{array}{l}\text { Leptospirose } \\
\text { Leptospira interrogans }\end{array}$ & $\begin{array}{l}\text { Roedores } \\
\text { Carnívoros }\end{array}$ & $\begin{array}{l}\text { Contato de mucosas ou pele } \\
\text { com água, fômites ou alimentos } \\
\text { contaminados com urina dos } \\
\text { animais (fontes de infecção). }\end{array}$ \\
\hline $\begin{array}{l}\text { Raiva } \\
\text { Lyssavirus }\end{array}$ & $\begin{array}{l}\text { Morcegos e } \\
\text { carnívoros (sic) }\end{array}$ & Mordedura de animais raivosos. \\
\hline $\begin{array}{l}\text { Salmonelose } \\
\text { Salmonella spp }\end{array}$ & $\begin{array}{l}\text { Répteis } \\
\text { Aves } \\
\text { Mamíferos }\end{array}$ & Ingestão de salmonelas viáveis. \\
\hline $\begin{array}{l}\text { Sarcocistose } \\
\text { Sarcocystis spp }\end{array}$ & $\begin{array}{l}\text { Carnívoros } \\
\text { Herbívoros }\end{array}$ & $\begin{array}{l}\text { Ingestão de oocistos no meio } \\
\text { ambiente e carnivorismo } \\
\text { (ingestão de sarcocistos). }\end{array}$ \\
\hline $\begin{array}{l}\text { Toxoplasmose } \\
\text { Toxoplasma gondii }\end{array}$ & $\begin{array}{l}\text { Felídeos e animais } \\
\text { endotérmicos. }\end{array}$ & $\begin{array}{l}\text { Ingestão de oocistos } \\
\text { esporulados na água e alimentos } \\
\text { contaminados, carnivorismo } \\
\text { (cistos teciduais-bradizoítas) ou } \\
\text { transplacentária (taquizoítas). }\end{array}$ \\
\hline
\end{tabular}




\begin{tabular}{|l|l|l|}
\hline $\begin{array}{l}\text { Tuberculose } \\
\text { Mycobacterium }\end{array}$ & $\begin{array}{l}\text { Herbívoros, } \\
\text { Carnívoros, } \\
\text { tuberculosis } \\
\text { Micobacterium bovis }\end{array}$ & $\begin{array}{l}\text { Através da inalação de esporos } \\
\text { no meio ambiente, } \\
\text { primatas. }\end{array}$
\end{tabular}

Fonte: SILVA (2004)

VASCONCELOS (2001) destaca o papel dos animais vertebrados como fontes de infecção e reservatórios de agentes de doenças transmissíveis para os seres humanos, tanto os doentes como os portadores. Os doentes desempenham um papel limitado, enquanto que os portadores encerram importância epidemiológica por aparentarem perfeito estado de saúde e terem livre movimentação.

De acordo com Bouer, citado por RENCTAS (2001, p. 55), já são conhecidos mais de 180 tipos de doenças que podem ser transmitidas dos animais para os seres humanos, principalmente quando provenientes do comércio ilegal. A situação de estresse leva à queda de resistência imunológica que pode propiciar o desenvolvimento de doenças transmissíveis, tornando-os portadores de agentes infecciosos.

Para OLIVIERA (2000), a maioria dos animais comercializados ilegalmente no Brasil pertence à classe das aves e partem de estados como a Bahia e Minas Gerais, sendo normalmente destinados aos grandes centros urbanos como os estados do Rio de Janeiro e São Paulo, onde são vendidos em feiras ou traficados para outros países. A malha rodoviária é bastante empregada para o comércio interno, e as rodovias BR-116 (Rio - Bahia) e a Fernão Dias (Belo Horizonte - São Paulo) são exemplos de locais onde animais silvestres são apreendidos em grande número pelos órgãos de fiscalização. Segundo a RENCTAS (2001), entre 1992 e 2000 foram apreendidos no Brasil 263.932 animais silvestres.

São Paulo é um grande consumidor de animais silvestres provenientes do tráfico. Segundo LO (2006), “apenas no Estado de São Paulo, os animais silvestres irregulares (sic) apreendidos chegaram ao impressionante número de aproximadamente 30 mil espécimes. Certamente uma pequena parcela do montante traficado” (p. 5). 
O número das apreensões realizadas pela Polícia Ambiental do Estado de São Paulo vem aumentando significativamente no período de 1999 a 2005 (figura 3).

Figura 3 - Número de animais silvestres apreendidos pela Polícia Ambiental do Estado de São Paulo, no período de 1999 a 2005.

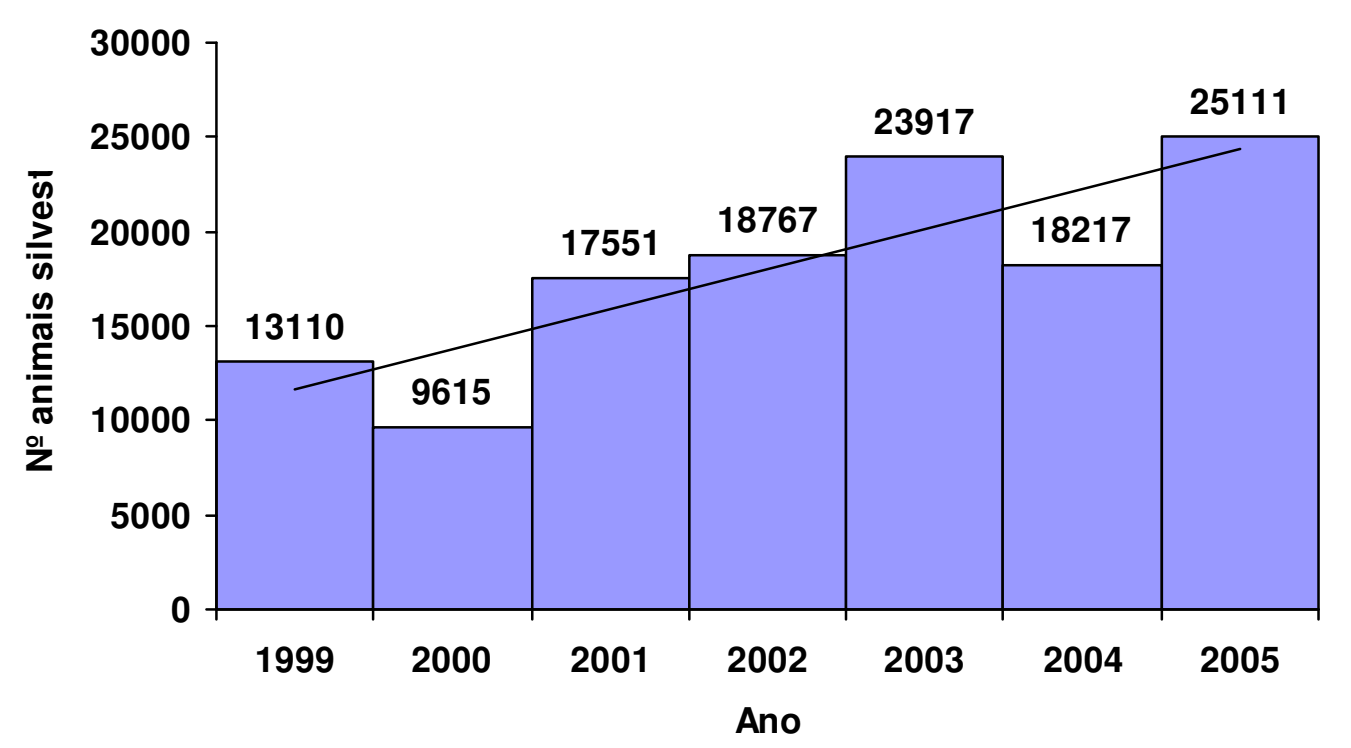

Fonte: RENCTAS (2007, p. 97).

O número de apreensões realizadas em São Paulo apresenta uma linha de tendência de crescimento constante, exceto os anos de 2000 e 2004 quando esse número foi menor que do ano anterior, sem que os motivos pudessem ser apurados. O aumento entre o início e o final da série foi de 1,91 vezes.

Segundo a Lei de Crimes Ambientais, os animais apreendidos devem ser libertados em seu hábitat ou entregues a jardins zoológicos, fundações ou entidades assemelhadas, desde que fiquem sob a responsabilidade de técnicos habilitados.

No Estado de São Paulo, poucos animais são liberados para a natureza, a maioria é destinada para o cativeiro (figura 4). 
Figura 4 - Percentual do número de animais destinados pela Polícia Ambiental do Estado de São Paulo, frente ao local de destino.

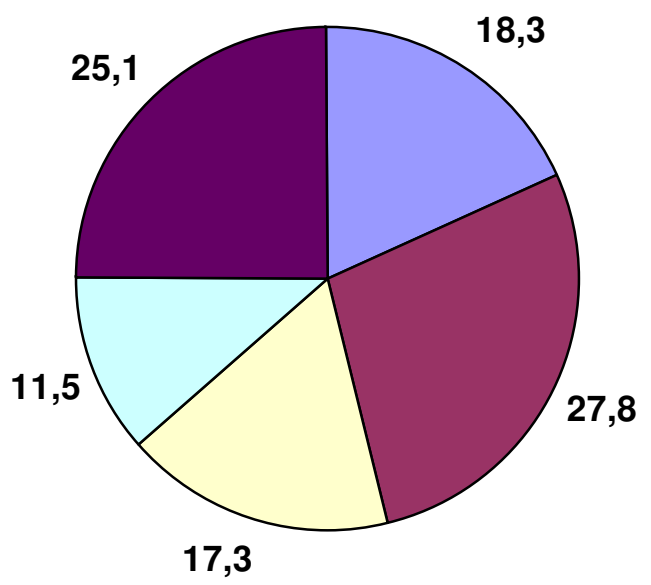

\section{$\square$ SOLTURA $\square$ CETAS $\square$ ZOO $\square$ CRIADOU $\square$ OUTROS}

Fonte: RENCTAS (2007, p. 97).

Em São Paulo, menos que 20\% dos animais apreendidos retornam para a natureza. Entre os 25,1\% atribuídos a outros destinos, a Polícia Ambiental informou que 20,1\% permaneceram com os próprios autuados (RENCTAS, 2007).

Entre as espécies mais apreendidas pelos órgãos de fiscalização, em cinco estados brasileiros, estão os animais listados pelo nome comum, em ordem alfabética (quadros 2, 3, 4): 
Quadro 2 - Lista dos mamíferos mais apreendidos pela Polícia Ambiental e IBAMA nos Estados de São Paulo, Rio de Janeiro, Minas Gerais, Espírito Santo e Bahia, no período de 1999 a 2005.

\begin{tabular}{|l|l|}
\hline \multicolumn{1}{|c|}{ NOME COMUM } & \multicolumn{1}{c|}{ NOME CIENTÍFICO } \\
\hline Bicho-preguiça & Bradypus sp \\
\hline Bugio & Alouatta sp \\
\hline Cachorro-do-mato & Cerdocyon thous \\
\hline Capivara & Hydrochoeris hydrochaeris \\
\hline Cateto & Tayassu tajacu \\
\hline Cutia & Dasyprocta azarae \\
\hline Gambá & Didelphis sp \\
\hline Gambá-de-orelha-preta & Didelphis aurita \\
\hline Gato-do-mato-pequeno & Leopardus tigrinus \\
\hline Lobo-guará & Chrysocyon brachyurus \\
\hline Macaco-prego & Cebus sp \\
\hline Ouriço-cacheiro & Sphiggurus villosus \\
\hline Paca & Agouti paca \\
\hline Quati & Nasua nasua \\
\hline Raposa & Não identificado \\
\hline Sagüi & Callithrix sp \\
\hline Sagüi-de-cara-branca & Callithrix geoffroyi \\
\hline Sagüi-de-tufo-branco & Callithrix jacchus \\
\hline Sagüi-de-tufo-preto & Callithrix penicillata \\
\hline Tamanduá & Tamandua tetradactyla \\
\hline Tatu & Ozotocerus bezoarticus \\
\hline Veado-campeiro & \\
\hline Fontentificado \\
\hline RENCTAS (2007, p.108) \\
\hline
\end{tabular}

Fonte: RENCTAS (2007, p.108). 
Quadro 3 - Lista das aves mais apreendidas pela Polícia Ambiental e IBAMA, nos Estados de São Paulo, Rio de Janeiro, Minas Gerais, Espírito Santo e Bahia, no período de 1999 a 2005.

\begin{tabular}{|l|l|}
\hline \multicolumn{1}{|c|}{ NOME COMUM } & \multicolumn{1}{|c|}{ NOME CIENTÍFICO } \\
\hline Arara-canindé & Ara ararauna \\
\hline Azulão & Passerina brissonii \\
\hline Bico-de-lacre & Estrilda astrild \\
\hline Bigodinho & Sporophila lineola \\
\hline Brejal & Sporophila albogularis \\
\hline Caboclinho & Sporophila sp \\
\hline Canário & Não identificado \\
\hline Canário chapinha & Sicalis flaveola \\
\hline Canário da terra & Sicalis flaveola \\
\hline Cardeal & Paroaria coronata \\
\hline Coleiro & Sporophila sp \\
\hline Coleiro-baiano & Sporophila nigricollis \\
\hline Coruja & Não identificado \\
\hline Curió & Oryzoborus angolensis \\
\hline Galo-da-campina & Paroaria dominicana \\
\hline Jandaia & Não identificado \\
\hline Maracanã & Não identificado \\
\hline Maritaca & Não identificado \\
\hline Papagaio & Amazona sp \\
\hline Pássaro-preto & Gnorimopsar chopi \\
\hline Periquito & Não identificado \\
\hline Picharro & Saltator maximus \\
\hline Pintassilgo & Carduelis sp \\
\hline Pichochó & \\
\hline Sabiá & Sporophila frontalis \\
\hline
\end{tabular}




\begin{tabular}{|l|l|}
\hline Sanhaço & Não identificado \\
\hline Sofrê & Icterus $s p$ \\
\hline Tico-tico & Não identificado \\
\hline Tiziu & Volatinia jacarina \\
\hline Trinca-ferro & Saltator similis \\
\hline Tuim & Forpus xanthopterygius \\
\hline
\end{tabular}

Fonte: RENCTAS (2007, p.109).

Quadro 4 - Lista dos répteis mais apreendidos pela Polícia Ambiental e IBAMA nos Estados de São Paulo, Rio de Janeiro, Minas Gerais, Espírito Santo e Bahia, no período de 1999 a 2005.

\begin{tabular}{|l|l|}
\hline \multicolumn{1}{|c|}{ NOME COMUM } & \multicolumn{1}{c|}{ NOME CIENTÍFICO } \\
\hline Cágado & Phrynops geoffroanus \\
\hline Camaleão & Não identificado \\
\hline Cascavel & Crotalus durissus \\
\hline Cobra-d'água & Não identificado \\
\hline Coral & Não identificado \\
\hline Falsa-coral & Não identificado \\
\hline Iguana & Iguana iguana \\
\hline Jabuti & Geochelone sp \\
\hline Jabuti-piranga & Geochelone carbonaria \\
\hline Jacaré & Não identificado \\
\hline Jacaré-de-papo-amarelo & Caiman latirostris \\
\hline Jararaca & Bothrops sp \\
\hline Jararacuçu & Bothrops sp \\
\hline Jibóia & Boa constrictor \\
\hline Lagarto & Não identificado \\
\hline Serpente & Não identificado \\
\hline Sucuri & Eunectes murinus \\
\hline
\end{tabular}




\begin{tabular}{|l|l|}
\hline Tartaruga & Não identificado \\
\hline Teiú & Tupinambis merianae \\
\hline Tigre-d'água & Trachemys $s p$ \\
\hline Urutu & Bothrops alternatus \\
\hline
\end{tabular}

Fonte: RENCTAS (2007, p. 110).

A RENCTAS esclarece que "as listas foram elaboradas a partir dos nomes comuns e científicos dos animais mais apreendidos, fornecidos pela Polícia Ambiental e IBAMA, nos cinco estados. Alguns nomes comuns aparecem sem os correspondentes nomes científicos (não identificado) pela impossibilidade de correlação, devido à ausência de dados mais específicos por parte dos órgãos fiscalizadores” ( p. 110).

O conhecimento sobre as espécies mais apreendidas ajuda a planejar as ações de resgate, que é a primeira etapa nas operações de fiscalização.

\subsection{GESTÃO E MANEJO DA FAUNA SILVESTRE NATIVA RESGATADA}

A maior parte dos animais resgatados, principalmente por apreensões realizadas por órgãos de fiscalização, é entregue a criadouros amadores, conservacionistas e jardins zoológicos, que podem ser públicos ou privados.

A Lei Federal $\mathrm{n}^{\circ}$ 7.173, de 14 de dezembro de 1983, artigo $1^{\circ}$ considera "jardim zoológico qualquer coleção de animais silvestres mantidos vivos em cativeiro ou em semiliberdade e expostos a visitação pública". Assim, aqueles animais resgatados que são entregues em zoológicos, mesmo públicos, não serão tratados nesta pesquisa por passarem a compor o acervo da instituição.

A pesquisa está voltada aos serviços públicos com enfoque para a fauna vitimada, que atendam o disposto na legislação, atuando com novas práticas que possam diminuir a retirada de exemplares da natureza, aprimorar o manejo e conhecimento sobre as espécies e possibilitar que os animais sejam recolocados em seu hábitat, mitigando ou compensando os danos causados pela pressão humana. 
Outro enfoque está relacionado à atuação dos serviços na área de saúde pública, uma vez que os animais podem ser fontes de infecção e reservatórios de agentes etiológicos causadores de zoonoses que afetam a população humana.

Para OJASTI (2000), a gestão da fauna, em nível de países, compreende quatro aspectos principais:

1. Planejamento;

2. Política;

3. Legislação;

4. Administração.

Todos esses aspectos parecem pouco atrativos para pessoas orientadas sob os aspectos biológicos, porém, são de vital importância para a constituição de um marco de referência formal que os países conduzem em seu território.

O planejamento é o processo de avaliação de alternativas e tomada de decisões, levando em consideração as escalas temporais, espaciais e hierárquicas. "O planejamento contribui para hierarquizar e integrar planos e ações, definir prioridades, prevenir as necessidades humanas, minimizar erros e conflitos, erradicar os vícios acumulados pela inércia institucional, incluindo a duplicidade e a dispersão de esforços e otimizando o uso dos recursos disponíveis" (a tradução é nossa) (OJASTI, 2000, p. 68).

A política engloba as intenções, diretrizes, obrigações e a orientação geral de uma entidade, e os governos a executam da forma que lhes parece mais correta e conveniente em termos políticos, socioeconômicos e ambientais. Dessa forma, enquanto alguns países permitem, por exemplo, a exploração da caça desportiva e até a comercial de animais vivos, outras a proíbem expressamente. No geral, poucos países contam com um documento formal sobre sua política de fauna, refletindo a baixa prioridade com que o assunto vem sendo tratado.

Segundo Wing, citado por OJASTI (2000, p. 62), a legislação trata de como a fauna está inserida no direito ambiental e tem por finalidades proteger o interesse público, controlar o impacto humano sobre a fauna e assegurar a todos os cidadãos o mesmo acesso ao recurso. 
A administração da fauna tradicionalmente está sob a responsabilidade dos Ministérios da Agricultura, e mais recentemente, também do Meio Ambiente, cabendo a esses órgãos através de seus serviços de fauna, executar a política delineada para o seu próprio território. Ela é realizada por meio de normas, liberação de licenças e aplicação de sanções, além de outras funções mais específicas, levando em consideração o cumprimento de tratados internacionais, quando os países são signatários.

Segundo OJASTI (2000), é na esfera administrativa que são realizadas: as pesquisas, que são ferramentas básicas para a tomada de decisões e manejo da fauna; a fiscalização, assegurando o fiel cumprimento das normas legais e técnicas de manejo, complementada pela educação; além da promoção da participação pública por meio de consulta aos diversos setores vinculados com o recurso, como os proprietários rurais, pesquisadores e organizações não governamentais.

$\mathrm{O}$ autor afirma, ainda, que a consolidação dos serviços de fauna é vital para a reorientação das políticas inspiradas na integração da conservação e o desenvolvimento, considerando os novos desafios da expansão demográfica das próximas décadas.

No que tange ao manejo da fauna, essa é uma atividade interdisciplinar que constitui um importante mercado de trabalho para biólogos, engenheiros florestais, agrônomos e veterinários (OJASTI, 2000).

Para CLARK (1999), o manejo significa exercer controle sobre as interações do homem com a vida silvestre, assim, atividades como a caça, pesca, captura, posse e venda dos animais são definidos e determinados em instrumentos regulamentadores que variam de acordo com as circunstâncias biológicas, como a flutuação de populações de animais, o hábitat, clima, etc. Todavia, as regulamentações são afetadas por valores e opiniões do público, costumes e tradições, influência política, onde as considerações científicas não são necessariamente as mais importantes.

Ainda, segundo o autor, na maioria das nações, a autoridade para o manejo dos recursos silvestres tem sido delegada a uma agência de vida silvestre, Ministério do Interior ou agência equivalente dentro do ramo administrativo de governo. Além do manejo e combate ao comércio ilegal, cabe a esses órgãos regular o cuidado e a posse de animais individuais, o uso educacional, a exibição e reabilitação (CLARK JR., 1999). 
Os animais apreendidos do comércio ilegal, bem como os já domesticados e não mais desejados por seus compradores, ficam à disposição e ao critério da sociedade, representada em alguns casos por funcionários do governo e particulares que assumem a tarefa de resgatá-los. Nos resgates, também estão incluídos animais órfãos, feridos ou enfermos que são entregues para entidades e pessoas autorizadas. (DREWS, 1999).

Para SOORAE e PRICE (1999), as autoridades governamentais quando apreendem animais passam a ter responsabilidade de acomodá-los de maneira apropriada e visam as seguintes metas:

- Maximizar o valor da conservação dos animais apreendidos sem colocar em perigo a saúde, o comportamento, as características genéticas ou o estado de conservação dos animais silvestres cativos;

- Desestimular o comércio ilegal ou irregular dessas espécies;

- Viabilizar uma solução humanitária que pode ser a manutenção do animal em cativeiro ou seu retorno à vida silvestre;

- Realizar a eutanásia.

Segundo esses autores, em 1992 a IUCN/SSC ${ }^{8}$, a partir de um Grupo de Especialistas de Reintrodução (RSG), iniciou um trabalho para encarar o problema dos animais apreendidos. O trabalho foi desenvolvido em conjunto com a Traffic International ${ }^{9}$ com o auxílio de pesquisadores interessados no assunto, e que culminou na Resolução Conf. $9.10^{10}$, sobre a disposição de espécimes ilegalmente comercializadas e confiscadas, adotada na 14a . Conferência das Partes da Convenção sobre o Comércio Internacional das Espécies da Fauna e da Flora Selvagens Ameaçadas de Extinção $(\mathrm{CITES})^{11}$.

\footnotetext{
${ }^{8}$ IUCN - International Union for Conservation of Nature; SSC - Specialist Group; RSG - Reintroduction Specialist Group.

${ }^{9}$ Traffic International é uma rede de trabalho para monitorar o comércio de animais e plantas silvestres.

${ }^{10}$ Resolução Conf. 9.10 - Disposal of illegally traded, confiscated and accumulated specimens.

${ }^{11}$ CITES -Convention on International Trade in Endangered Species of Wild Fauna and Flora é um acordo multilateral com o objectivo de assegurar que o comércio de animais e plantas selvagens, e de produtos deles derivados, não pondo em risco a sobrevivência das espécies.
} 
O grupo traçou os seguintes destinos para os animais apreendidos vivos: transferência para programas de criação em cativeiro e reintrodução; retorno ao ambiente silvestre; cativeiro; e eutanásia.

Uma vantagem no retorno do animal ao ambiente silvestre é o aumento de populações onde estas possam estar ameaçadas. A eutanásia também é indicada como uma solução, apoiada em considerações econômicas, de conservação e até mesmo de bem-estar do animal, porém, há muitos pesquisadores contrários a essa prática e que buscam soluções para o problema, que não implique na penalização do animal com a morte.

Quando se trata de animais apreendidos, apenas um pequeno número pode ser solto, e segundo o Guia de Reintrodução da IUCN/SSC RSG (1995), o retorno para a natureza deve atender demandas de: reintrodução; reforçamento ou suplementação; conservação e introduções benignas.

LO (2006), adaptado da IUCN (1995) ${ }^{12}$, explica que soltura é um termo empregado genericamente para as seguintes práticas:

Reintrodução ou restabelecimento: tentativa de se estabelecer uma espécie em área da qual anteriormente fazia parte de seu histórico, mas da qual foi extirpado ou se tornou extinto;

Relocação ou translocação: movimento deliberado ou mediado, de indivíduos selvagens ou de populações de sua área de atuação para outra área em que ela também ocorre.

Recolocação é a devolução do indivíduo ou grupo da mesma localidade de origem, num curto espaço de tempo.

Revigoramento: soltura de indivíduos de uma espécie com a intenção de aumentar o número de indivíduos de uma população em seu hábitat e distribuição geográfica originais.

Introdução de conservação: tentativa de se estabelecer uma espécie, para o propósito de conservação fora de sua área de ocorrência, mas dentro de um hábitat apropriado.

${ }^{12}$ IUCN - Guidelines for Reintroductions, 41 ${ }^{\circ}$. Reunião do Conselho da IUCN, Gland, Suíça, maio 1995. 
Esses conceitos são de extrema importância e devem ser considerados pelos serviços e pessoas que atuam em centros de resgate de fauna, tanto apreendida como vitimada pela pressão antrópica.

A discussão sobre a destinação de animais se fortaleceu na década de 1990, desencadeando uma série de estudos realizados por entidades de caráter internacional, visando à solução de problemas envolvendo animais resgatados, mas que não comprometessem a conservação das espécies. Por essa razão, várias publicações e eventos foram realizados após a divulgação das diretrizes para a reintrodução de animais. No final dessa década, já era possível contatar instituições e indivíduos que praticavam a reabilitação, no mundo, a partir de uma publicação elaborada pelo RSG $R e$ introduction Specialist Group da IUCN, chamada Re-introduction Practioner's Directory $1998^{13}$.

Para Swiff et al. e Medaglia, citados por DREWS (1999), na região do Neotrópico são numerosas as iniciativas de resgate de fauna, e quase todas têm partido de pessoas particulares, cuja boa fé e compromisso com o bem-estar dos animais os têm levado a dedicar recursos de tempo, humanos e financeiros para a reabilitação e disposição final da fauna resgatada. Posteriormente, essas pessoas se comunicam com as autoridades governamentais, geralmente ligadas a ministérios como do meio ambiente e agricultura, que de modo geral, entregam a custódia e a disposição dos animais para entidades particulares e organizações não governamentais, cujo trabalho dificilmente atende a legislação.

Segundo HOYT (1999), a menos que existam leis que regulem as ações dos exploradores de animais, e força para cumpri-las prendendo os infratores, pouco poderá ser feito com relação à reabilitação e soltura. O problema deve ser resolvido no seu começo e não somente no lugar da conseqüência.

Para CLARK JR. (1999), a regulamentação governamental sobre a reabilitação de animais deve levar em consideração a localidade, país ou região, devendo ser realista em relação à habilidade dos reabilitadores, não existindo razão para estabelecer padrões

\footnotetext{
${ }^{13}$ Re-introduction Practioner's Directory 1998. Disponível em: <http://www.iucnsscrsg.org/download/ReintrdDirect1998.pdf>. Acesso em: 07 maio 2008.
} 
tão altos que as organizações não possam cumpri-los, especialmente considerando as limitações financeiras e falta de apoio público. Na identificação e definição dos padrões mínimos para a reabilitação da fauna silvestre, os governos devem considerar as práticas aceitáveis na atualidade entre os profissionais e refleti-las em suas normativas. Um sistema regulador efetivo deve dar incentivos e requerimentos que alimentem os reabilitadores a atualizarem-se e empregar técnicas avançadas para esse fim.

Independente da nomenclatura dada aos locais para onde são encaminhados os animais, alguns autores preconizam que os mesmos sejam entregues em centros que resgatam, reabilitam ou manejam os animais visando a sua devolução ao hábitat natural.

JIMÉNEZ-PÉREZ (1999, p. 68) define como centro de resgate "aqueles estabelecimentos públicos ou privados que contam com instalações capacitadas para receber, alojar e reabilitar exemplares da fauna silvestre provenientes de apreensões, doações, ou encontrados acidentados" (a tradução é nossa).

Para HERNÁNDEZ (1999), o resgate inclui em seu sentido amplo as fases de resgate propriamente dita, custódia, transporte, reabilitação, readaptação e a liberação do animal.

Segundo DREWS (1999, p. 470), "um centro de resgate e ou reabilitação de fauna silvestre é um lugar onde se recebe animais silvestres com a finalidade de habilitálos novamente para regressarem ao seu hábitat natural" (a tradução é nossa).

Para SOORAE e PRICE (1999), os centros de resgates "são estabelecidos principalmente para tratar indivíduos feridos ou confiscados" (a tradução é nossa) (p. $63)$.

No Brasil, segundo o IBAMA (2008), o Centro de Triagem de Animais Silvestres (CETAS) é um local com finalidade de recepcionar, triar e tratar os animais silvestres resgatados ou apreendidos pelos órgãos fiscalizadores, assim como, eventualmente, receber animais silvestres de particulares que os estavam mantendo em cativeiro domésticos de forma irregular como animais de estimação.

BRANCO (2002) define um Centro de Manejo de Animais Silvestres (CEMAS) como uma instituição de estudos e informações sobre fauna e meio ambiente, baseada nos princípios da proteção, pesquisa e educação, que tem como objetivos contribuir com 
a preservação do meio e vigilância ambiental. Trata-se de um serviço de recepção de animais silvestres vitimados, onde é prestado o atendimento médico - veterinário com suporte laboratorial e acompanhamento biológico, visando a plena recuperação do animal para primordialmente reintegrá-lo à natureza. Para a autora, o manejo compreende todos os procedimentos realizados com os animais durante a sua internação, que envolve: captura, contenção, transporte, atendimento médico-veterinário, atendimento biológico, ambientação, alimentação, reabilitação, soltura.

Para CLARK JR. (1999), a reabilitação da vida silvestre é um meio pelo qual, animais que foram retirados da natureza podem ser restituídos à mesma, e sem a qual, a maioria dos animais apreendidos morreria ou terminaria como mascotes ilegais.

Em comum, nesses centros voltados para a fauna, a unidade de trabalho é o animal como indivíduo, tendo como um dos objetivos a melhoria das condições de vida dos animais resgatados, possibilitando a sua devolução à natureza e contribuindo para a conservação das espécies.

Para CLARK JR. (1999), um programa de resgate de fauna silvestre deve repousar sobre três pilares:

1. Bom cuidado e reabilitação dos animais;

2. Educação do público;

3. Participação na política e em atividades de manejo que incorporem conhecimentos adquiridos a partir dos animais cativos para o benefício da fauna em geral.

"Os centros de resgate de fauna podem colaborar com a conservação de espécies ameaçadas mediante o desenvolvimento de atividades de pesquisa, educação, cria e reintrodução de exemplares cativos. Os animais que transitam por estes centros podem fornecer uma valiosa informação biológica" (a tradução é nossa) (JIMÉNEZ-PÉREZ 1999, p. 68-69).

De acordo com Hiraldo e Heredia, citados por JIMÉNEZ-PÉREZ (1999, p. 69), as pesquisas normalmente realizadas nos centros estão relacionadas às espécies ameaçadas de extinção ou relativas às áreas de comportamento, fisiologia, enfermidades, 
alimentação, metabolismo, bioenergética, reprodução, sexagem, inseminação artificial, foto período, incubação e investigações hematológicas e sorológicas.

Porém, deve ser considerado que nos centros, as pesquisas são mais uma exceção do que uma regra, e que a maior parte deles gasta suas energias no restabelecimento da saúde dos indivíduos ingressados, ao invés de dedicarem grandes esforços ou fundos para o desenvolvimento de protocolos de pesquisa. Assim, as pesquisas são escassas e quando realizadas normalmente focam mais os aspectos veterinários que os ecológicos relacionados com a conservação das espécies (JIMÉNEZ-PÉREZ, 1999).

Para Kleiman; Gaughley e Gunn, citados por JIMÉNEZ-PÉREZ (1999, p. 82), apesar dos obstáculos, a reabilitação de animais pode ser uma das últimas esperanças para as espécies cujas populações se encontram em estado crítico na natureza. Esse é um caso onde os centros também desempenham um papel importante no processo de conservação da população, que vai além de reabilitar um exemplar e soltá-lo em seu meio natural. Porém, isto implica na necessidade de trabalhos voltados a educação ambiental, proteção e manejo do hábitat, acompanhamento dos animais liberados, e solução das causas do declínio populacional.

"A complexidade deste enfoque multidirecional e o tipo dos meios e pessoal encontrados nos centros de resgate, fazem com que o papel destes no processo de recuperação de uma espécie seja geralmente de colaboradores e não de executores principais" (a tradução é nossa) (JIMÉNEZ-PÉREZ, 1999, p. 82).

CLARK JR (1999) afirma que nas recolocações e reintroduções, tanto as energias como os fundos se focalizam no restabelecimento e na liberação dos animais, sem que haja uma seção do centro dedicada ao acompanhamento dos animais, com a finalidade de avaliar o êxito do processo. Afirma, ainda, que os centros com maiores recursos econômicos e humanos dos países desenvolvidos não são uma exceção a este respeito.

O destino ideal para os animais regatados é o retorno para a natureza, porém, essa prática não é adotada na maioria dos casos, quer seja pela inaptidão dos animais para sobreviverem em liberdade ou por falta de conhecimentos técnicos e recursos para que os procedimentos ocorram de maneira profissional. Reconhecendo tais deficiências, 
a maioria dos resgatadores de animais busca assessoria técnica de biólogos e veterinários, assim como buscam capacitação em áreas administrativas e de estruturação de centros de resgate. (DREWS, 1999).

Aqueles animais que não podem ser reintegrados ao seu meio natural, ainda podem ser úteis quando destinados para zoológicos e criadouros para reprodução em cativeiro. Um animal que não pode regressar ao seu meio pode contribuir com a população silvestre com seu patrimônio genético. (CLARK JR., 1999).

Ainda que a reprodução em cativeiro não seja reabilitação da vida silvestre, ela pode ter importância na reintrodução de animais silvestres em hábitats restaurados, ou naqueles em que certas espécies não existam devido a influências externas como a caça de espécies proibidas, enfermidades e presença de espécies exóticas, entre outras (CLARK JR., 1999).

HOYT (1999) entende que "somente os animais que não estão sofrendo por feridas ou outro tipo de trauma, seja físico ou psicológico, devem ser considerados para reabilitação e postos em liberdade, exceto naqueles casos especiais quando medidas extraordinárias poderiam justifica-la para a preservação de espécies em perigo" (a tradução é nossa) (p. 57).

Para a The Humane Society of the United States (HSUS) existe um compromisso onde tudo que está ao seu alcance deve ser feito para combater a exploração da vida silvestre, e quando for possível e eticamente apropriado, ajudar a retornar os animais capturados a seu hábitat natural. "Assim como nós, eles têm capacidade de experimentar satisfação e prazer, e experimentar a dor e o sofrimento da separação, do isolamento e da privação, sem mencionar o patente abuso que na maioria das vezes se associa com a sua captura e subseqüente confinamento" (a tradução é nossa) (HOYT, 1999, p. 55-56).

Mas também é conhecido o fato de que, quanto mais se afasta um animal silvestre de seu hábitat natural, mais difícil é a possibilidade de sua recolocação na natureza. Mesmo assim, para GRANDY (1999, p. 63), "O êxito ou fracasso de poucos programas de reintrodução realizados até agora não devem impedir ou atrasar os esforços de reabilitação" (a tradução é nossa). 
Segundo JIMÉNEZ-PÉREZ (1999), algumas críticas direcionadas aos centros de reabilitação não dizem respeito propriamente às práticas nele realizadas, mas sim, questionam o verdadeiro papel desempenhado para a conservação da biodiversidade, uma vez que eles competem pela obtenção de fundos com outros programas de conservação, ditos mais úteis.

Independente da disputa por recursos, tanto nos Estados Unidos como em outros países do mundo, centenas de milhares de aves, mamíferos, répteis e anfíbios vêm sendo resgatados ou assistidos, fazendo com que esta atividade evoluísse como uma arte e uma ciência sofisticada e padronizada, e passando a ser tratada como uma profissão. Já existem diversas organizações nacionais e internacionais trabalhando na reabilitação da vida silvestre, livros e revistas publicadas, centros voltados de treinamento de pessoal, medidas legais que se aplicam a este campo, redes de reabilitadores e cursos associados com instituições de ensino superior (GRANDY, 1999).

Para esse autor, o envolvimento das ciências nessa área é extremamente importante para maximizar a oportunidade de reabilitação e obtenção de êxito na liberação do animal. Nesse sentido, a importância do conhecimento de fisiologia animal, anatomia, comportamento, nutrição, bem como o diagnóstico e tratamento dos problemas médicos são essenciais, além de estratégicas para a liberação do animal.

JIMÉNEZ-PÉREZ (1999) afirma que a maioria dos centros e especialmente no Neotrópico, vive em um estado crônico de penúria econômica e de pessoal. As equipes, apesar de demonstrarem uma grande motivação pelo trabalho, normalmente encontramse sobrecarregada de múltiplas funções e carecem de tempo e de recursos para capacitarem-se, demonstrando-se muitas vezes frustrados pelo pouco apoio governamental que recebem pelo seu trabalho.

A existência de centros de resgate financiados com dinheiro público implica que uma nação ou região está disposta a investir seus impostos a melhorar as condições de saúde de seus animais silvestres. Inclusive, em muitos casos, a sociedade civil tem um papel ativo nesse processo, bem seja levando os animais enfermos aos centros ou apresentando-se como voluntária para curar e alimentar alguns dos animais. $\mathrm{O}$ impacto que esta atitude e participação podem ter sobre a conservação da fauna em seu 
meio natural resulta em difícil mensuração, porém não deve ser depreciada (a tradução é nossa) (p. 70).

O que nem sempre é considerado, é que os cuidados direcionados para os espécimes podem oferecer uma oportunidade única de apresentação da perspectiva ambiental e da problemática que afeta toda uma espécie ou a vida silvestre de uma determinada região. "Alguns dos problemas ambientais que afetam a fauna tem efeitos similares sobre as populações humanas. Assim, animais silvestres podem ser indicadores importantes da saúde ambiental em geral” (a tradução é nossa), (o destaque é nosso) (CLARK JR., 1999, p. 96).

Há inúmeros exemplos que ilustram como um só animal ajudou no descobrimento de um problema ambiental bastante sério. Um deles trata do relato do recebimento de uma Águia Calva - Bald Eagle (Haliaeetus leucocephalus) no centro de Vida Silvestre da Virginia, em 1985, que não podia voar devido ao envenenamento por pesticida.

Após investigação na área onde o animal havia sido encontrado, constatou-se que o agente causador do envenenamento era o carbofuron, utilizado no controle de insetos do solo. Após diversas pesquisas baseadas nos dados da Agência de Proteção Ambiental, concluíram que esse mesmo agente químico estava provavelmente matando entre 1 e 2 milhões de aves por ano.

Transcorridos seis anos, o agente químico foi retirado do mercado devido ao trabalho realizado em conjunto com departamentos e organizações de vida silvestre estatais e federais. “Cerca de 2 milhões de aves não morrerão este ano porque cuidamos de apenas uma águia em 1985" (a tradução é nossa), (o destaque nosso) (CLARK JR., 1999, p. 97).

Ainda, essa mesma águia possibilitou que fosse relacionado o grande número de atropelamentos envolvendo águias, falcões e corujas decorrentes de envenenamento por pesticidas. Por meio de provas sanguíneas rotineiras, foi possível determinar o nível mínimo de exposição ao pesticida que fazia com que os animais fossem mais propensos a acidentes (CLARK JR., 1999, p. 97). 
Nos Estados Unidos, $80 \%$ dos pesticidas são empregados em fazendas onde são freqüentes os acidentes ocupacionais causados por máquinas agrícolas. $\mathrm{O}$ trabalho com aves individuais demonstrou que a exposição a pesticidas aumenta a possibilidade de que um animal sofra um acidente. "Por que a mesma situação não poderia ser válida nos humanos? Cremos que a constante exposição de fazendeiros a pesticidas pode ser um fator contribuinte para a alta incidência de acidentes, lesões e mortes" (a tradução é nossa), (o destaque é nosso) (CLARK JR., 1999, p. 98).

Esse exemplo ilustra a importância da pesquisa e investigação das causas que vitimam os animais silvestres, pois um único espécime atendido pode estar refletindo um problema que afeta a saúde ou integridade de uma população ou de uma espécie numa determinada localidade, sob exposição de um fator de risco que também pode prejudicar a saúde humana.

Na cidade de São Paulo já é possível mapear locais com a presença do agente etiológico causador da leptospirose (Leptospira $s p$ ) e seus sorovares, a partir de animais silvestres atendidos no DEPAVE-3 (CORRADO, 2001), como os gambás (Didelphis $s p$ ), por meio de exames sorológicos (BERTOLA, 2004).

Esse exemplo mostra que, enquanto a pesquisa está restrita a apenas um animal não traz grande significado ou contribuição, mas quando é realizada de forma sistemática em dezenas ou centenas de animais, passa a apresentar um quadro do risco da distribuição da doença no ambiente, tornando a informação uma ferramenta para o seu controle, com vistas à saúde pública.

Para CLARK JR (1999), os centros de resgate também possuem um grande potencial para a realização de programas educacionais, pois o contato com o histórico de animais feridos por armas de fogo, atropelados, intoxicados, mal nutridos ou maltratados por comerciantes ilegais, podem provocar uma resposta positiva aos visitantes.

No entanto, a educação tende a adotar um papel marginal nos centros, com meios pouco profissionais e sem um claro enfoque sobre as necessidades reais de conservação da espécie em seu meio natural.

Para que os centros consigam o máximo efeito conscientizador devem incorporar a educação entre os seus objetivos principais, 
capacitar seu pessoal nesse sentido e investir em meios educativos associados a suas instalações de reabilitação da fauna, deixando claro perante o público que não são zoológicos cuja finalidade é mostrar animais silvestres aos visitantes (a tradução é nossa) (JIMÉNEZ-PÉREZ, 1999, p. 69).

Uma forma de explicar a problemática ambiental é mostrar seus efeitos, e não apresenta-los como conceitos abstratos. Tanto as crianças como os adultos têm dificuldades para entender o significado real da "perda de hábitat", assim, as histórias de animais vitimados pela perda do hábitat e de outros problemas ambientais, podem ilustrar o significado desta problemática (CLARK JR., 1999). "A reabilitação da fauna silvestre pode ser uma maneira dramática de ensinar que os animais servem para algo, e que merecem ser cuidados. Se não podemos convencer as pessoas que cuide de apenas um animal, como podemos convencê-las de que cuidem de todos os animais?" (a tradução é nossa), ( p.99).

\subsubsection{Centros Internacionais de Recepção de Fauna}

De acordo com JIMÉNEZ-PÉREZ (1999), a maioria dos países latino americanos conta com centros destinados a recuperar fauna silvestre (quadro 5), e muitas vezes o trabalho desses centros tem se apresentado contribuição para a conservação da biodiversidade da região. 
Quadro 5 - Sistematização sobre as políticas públicas e gestão da fauna silvestre nativa resgatada, em 12 países da Região Neotropical.

\begin{tabular}{|c|c|c|c|c|}
\hline $\begin{array}{l}\text { País } \\
\text { Autores } \\
\end{array}$ & Marco Legal & Iniciativas Institucionais & $\begin{array}{c}\begin{array}{c}\text { Instituiçõos ligadas ao } \\
\text { resgate de fauna } \\
\text { silvestre }\end{array} \\
\end{array}$ & Situação \\
\hline $\begin{array}{l}\text { APRILE e } \\
\text { BERTONATTI } \\
(1999)\end{array}$ & $\begin{array}{l}\text { - Lei Nacional } \\
22.421 / 81 \text { de } \\
\text { Conservação da } \\
\text { Fauna Silvestre. } \\
\text { - Decreto } \\
\text { Regulamentador } \\
\text { 666/97 } \\
\text { Art. } 48 \text { e } 49 \text { sobre o } \\
\text { destino dos animais } \\
\text { apreendidos. }\end{array}$ & $\begin{array}{l}\text { Em } 1993 \text { surge o } 1^{\circ} \text {. Centro de } \\
\text { Reabilitación de Fauna } \\
\text { Silvestre, mediante convênio } \\
\text { entre a Fundación Vida } \\
\text { Silvestre Argentina (FVSA) e a } \\
\text { Estación de Cria de Animales } \\
\text { Silvestres (ECAS) da Província } \\
\text { de Buenos Aires, que devido a } \\
\text { mudanças na estrutura política } \\
\text { de governo, encerrou suas } \\
\text { atividades. }\end{array}$ & $\begin{array}{l}\text { - Zoológicos; } \\
\text { - Centros de criação e } \\
\text { recuperação de animais; } \\
\text { - Fundações que } \\
\text { recepcionam e exibem } \\
\text { exemplares resgatados; } \\
\text { - Fundação Cullunche } \\
\text { que recepciona, confisca } \\
\text { e liberta animais } \\
\text { vitimados e apreendidos; } \\
\text { - Aquários. }\end{array}$ & $\begin{array}{l}\text { Não existe marco legal } \\
\text { sobre a criação da categoria } \\
\text { de centro de resgate e } \\
\text { reabilitação de animais e de } \\
\text { seu funcionamento. Se } \\
\text { houvesse, evitaria muitos } \\
\text { erros e desestimularia } \\
\text { iniciativas de instituições } \\
\text { precárias. }\end{array}$ \\
\hline PEREDO (1999) & \begin{tabular}{|l} 
- Lei de Meio \\
Ambiente 1333 de \\
27 de abril de 1992 e \\
- Decreto 22.641 de \\
8 de novembro de \\
1990.
\end{tabular} & $\begin{array}{l}\text { Não existe centros de resgate de } \\
\text { fauna silvestre operando no } \\
\text { país. } \\
\text { Existe instituições não } \\
\text { governamentais que atuam com } \\
\text { o Ministério de } \\
\text { Desenvolvimento Sustentável e } \\
\text { Planejamento, por intermédio da } \\
\text { Direção Geral de } \\
\text { Biodiversidade e a Unidade de } \\
\text { Vida Silvestre. }\end{array}$ & $\begin{array}{l}\text { - Zoológicos; } \\
\text { - Organizações não } \\
\text { governamentais. }\end{array}$ & $\begin{array}{l}\text { Poucas liberações de fauna } \\
\text { resgatada, geralmente em } \\
\text { propriedades privadas e com } \\
\text { resultados negativos. } \\
\text { Necessita de normas, infra- } \\
\text { estrutura, capacitação, } \\
\text { formação de recursos } \\
\text { humanos e de educação. }\end{array}$ \\
\hline
\end{tabular}




\begin{tabular}{|c|c|c|c|c|}
\hline $\begin{array}{l}\text { ZAMBRANO e } \\
\text { RODA (1999) }\end{array}$ & \begin{tabular}{|l} 
- Código de \\
Recursos Naturais \\
Renováveis Decreto \\
Lei 2.811 de 1974 e \\
Decreto $1.608 / 78$. \\
- Estatuto Geral de \\
Pesca Lei 13 de \\
1990. Decreto 2.256 \\
de 1991.
\end{tabular} & $\begin{array}{l}\text { Política Nacional Ambiental e } \\
\text { Programa de Proteção de } \\
\text { Ecossistemas Estratégicos, com } \\
\text { políticas para a gestão da fauna } \\
\text { silvestre. }\end{array}$ & $\begin{array}{l}\text { Organizações não } \\
\text { governamentais como: } \\
\text { - WSPA (Sociedade } \\
\text { Mundial para a Proteção } \\
\text { dos Animais); } \\
\text { - ADA (Associação } \\
\text { Defensora de Animais) }\end{array}$ & $\begin{array}{l}\text { Proposta de planejar uma } \\
\text { estratégia nacional para } \\
\text { manejo de espécimes da } \\
\text { fauna silvestre apreendida } \\
\text { com esforços } \\
\text { governamentais e não } \\
\text { governamentais. }\end{array}$ \\
\hline $\begin{array}{l}\text { CARVAJAL e } \\
\text { SOLANO (1999) }\end{array}$ & $\begin{array}{l}\text { - Lei de Conservação } \\
\text { da Vida Silvestre } \\
7.317 \text { de } 1992 . \\
\text { - Decreto N1 } 22.545 \\
\text { de } 1993 .\end{array}$ & $\begin{array}{l}\text { Ministério do Ambiente e } \\
\text { Energia e organizações como a } \\
\text { Unidade de Proteção da } \\
\text { Associação de Voluntários para } \\
\text { o Serviço de Áreas Protegidas } \\
\text { (ASVO), uma ONG. }\end{array}$ & $\begin{array}{l}\text { - Zoológicos; } \\
\text { - Criadouros; } \\
\text { - Centros de Resgate. }\end{array}$ & $\begin{array}{l}\text { Diversas entidades não } \\
\text { governamentais recebendo } \\
\text { animais apreendidos. } \\
\text { Diagnóstico e proposta de } \\
\text { modelo para o resgate de } \\
\text { fauna silvestre. }\end{array}$ \\
\hline LEMUS (1999) & Não citado. & $\begin{array}{l}\text { Ministério de Ciência, } \\
\text { Tecnologia e Meio Ambiente. } \\
\text { Todas as entidades são } \\
\text { governamentais e não existem } \\
\text { instituições privadas que } \\
\text { participem do resgate de fauna. }\end{array}$ & $\begin{array}{l}\text {-Zoológicos; } \\
\text { - Criadouros; } \\
\text { - Aquários. }\end{array}$ & $\begin{array}{l}\text { Não existe centro } \\
\text { especializado de resgate e } \\
\text { reabilitação da fauna } \\
\text { silvestre. } \\
\text { Somente realizam trabalhos } \\
\text { com espécies específicas de } \\
\text { interesse local. }\end{array}$ \\
\hline $\begin{array}{l}\text { LÓPES e } \\
\text { HERRERA } \\
(1999)\end{array}$ & $\begin{array}{l}\text { Lei de Conservação } \\
\text { de Vida Silvestre de } \\
4 \text { de junho de } 1994 .\end{array}$ & $\begin{array}{l}\text { Departamento de Vida Silvestre. } \\
\text { Direção Geral de Recursos } \\
\text { Naturais Ronováveis, por meio } \\
\text { do Serviço de Parques } \\
\text { Nacionais e Vida Silvestre e a } \\
\text { Fundação Zoológica de El } \\
\text { Salvador (FUNZEL). }\end{array}$ & $\begin{array}{l}\text { - Zoológico; } \\
\text { - Centro de resgate } \\
\text { - FUNZEL }\end{array}$ & $\begin{array}{l}\text { FUNZEL é uma organização } \\
\text { não governamental que } \\
\text { fundou o Centro de Resgate } \\
\text { e Reabilitação de Fauna } \\
\text { Silvestre em } 1995 .\end{array}$ \\
\hline
\end{tabular}




\begin{tabular}{|c|c|c|c|c|}
\hline $\begin{array}{l}\text { GUATEMALA } \\
\text { LARA e LÓPEZ } \\
\text { (1999) }\end{array}$ & $\begin{array}{l}\text { - Decreto 110-96 Lei } \\
\text { de Áreas Protegidas } \\
\text { e seu regulamento. }\end{array}$ & $\begin{array}{l}\text { Conselho Nacional de Áreas } \\
\text { Protegidas (CONAP) e } \\
\text { organização não governamental } \\
\text { como Associação para o } \\
\text { Resgate e Conservação de } \\
\text { Animais Silvestres (ARCAS). }\end{array}$ & $\begin{array}{l}\text { - Zoológico Nacional; } \\
\text { - Centros de resgate }\end{array}$ & $\begin{array}{l}\text { Proposta de planejamento de } \\
\text { um Centro Nacional de } \\
\text { Resgate de Fauna e Flora } \\
\text { Silvestre. }\end{array}$ \\
\hline $\begin{array}{l}\text { HONDURAS } \\
\text { STEINER (1999) }\end{array}$ & Decreto 001-90. & $\begin{array}{l}\text { Secretaria de Recursos Naturais } \\
\text { com a participação da } \\
\text { Sociedade Humanitarista dos } \\
\text { Estados Unidos (HSUS), } \\
\text { Fundación Cuero y Salado } \\
\text { (FUCSA) que criaram em } 1992 \\
\text { a Associação do Meio Ambiente } \\
\text { e Reabilitação de Aves } \\
\text { Silvestres (AMARAS). }\end{array}$ & - AMARAS & $\begin{array}{l}\text { Falta de recursos. } \\
\text { Esforços para a } \\
\text { implementação do Decreto } \\
001-90 .\end{array}$ \\
\hline $\begin{array}{l}\text { NICARÁGUA } \\
\text { PÉREZ (1999) }\end{array}$ & $\begin{array}{l}\text { - Lei Geral do Meio } \\
\text { Ambiente e dos } \\
\text { Recursos Naturais } \\
217 \text { de } 1996 . \\
\text { - Lei de Caça e seu } \\
\text { regulamento Decreto } \\
\text { Presidencial } 206 \text { de } \\
1956 .\end{array}$ & $\begin{array}{l}\text { Ministério do Ambiente e dos } \\
\text { Recursos Naturais. }\end{array}$ & Não citado. & $\begin{array}{l}\text { Grande oportunidade para } \\
\text { iniciar experiências na } \\
\text { reabilitação e liberação de } \\
\text { fauna silvestre. }\end{array}$ \\
\hline $\begin{array}{l}\text { PANAMÁ } \\
\text { MENDOZA } \\
(1999)\end{array}$ & $\begin{array}{l}\text { Lei } 24 \text { de } 7 \text { de junho } \\
\text { de } 1995 .\end{array}$ & $\begin{array}{l}\text { Instituto Nacional de Recursos } \\
\text { Naturais Renováveis } \\
\text { (INRERARE) }\end{array}$ & $\begin{array}{l}\text { Pequeno zoológico com } \\
\text { apoio do Parque } \\
\text { Municipal Summit. }\end{array}$ & $\begin{array}{l}\text { Pessoas que resgatam } \\
\text { animais feridos mantendo } \\
\text { em zoológicos particulares e } \\
\text { não comunicam ao } \\
\text { INRERARE. }\end{array}$ \\
\hline
\end{tabular}




\begin{tabular}{|l|l|l|l|l|}
\hline PERÚ & $\begin{array}{l}\text { Regulamento de } \\
\text { Zoocriadouro e } \\
\text { Áreas de Caça de 28 } \\
\text { de maio de 1992. } \\
\text { (1999) }\end{array}$ & $\begin{array}{l}\text { Instituto Nacional de Recursos } \\
\text { Naturais. }\end{array}$ & - Criadouros & $\begin{array}{l}\text { Necessita urgentemente de } \\
\text { centro de reabilitação e } \\
\text { liberação de fauna silvestre. }\end{array}$ \\
\hline VENEZUELA & $\begin{array}{l}\text { - Lei de Proteção à } \\
\text { Fauna Silvestre de } \\
\text { 1970 regulamentada } \\
\text { em 1975. } \\
\text { - Lei de Pesca de } \\
\text { 1944. }\end{array}$ & $\begin{array}{l}\text { Setor governamental por meio } \\
\text { do PROFAUNA. } \\
\text { Guarda Nacional e algumas } \\
\text { organizações não } \\
\text { governamentais. }\end{array}$ & $\begin{array}{l}\text { - Zoológicos; } \\
\text { - Criadouros } \\
\text { - Organizações não } \\
\text { governamentais }\end{array}$ & $\begin{array}{l}\text { O ordenamento e manejo da } \\
\text { fauna silvestre ocorre com } \\
\text { base no Plano de } \\
\text { Ordenamento e Manejo } \\
\text { nacional, regional, ou de } \\
\text { área ou setor específico. }\end{array}$ \\
\hline
\end{tabular}


Nota-se que os centros existentes estão sob a responsabilidade de organizações não governamentais (ONGs), zoológicos e criadouros. Não são reconhecidos legalmente e atuam com pouco ou nenhum critério técnico.

Nos últimos anos, poucas mudanças ocorreram no cenário internacional com relação ao quadro apresentado. O comércio ilegal se intensificou, os instrumentos legais não são voltados ao combate do tráfico de animais silvestres, as polícias não estão aparelhadas para o enfrentamento do problema, e faltam centros para atendimento de animais resgatados, a exemplo do que ocorre no Brasil (RENCTAS, 2007). A falta de normatização da atividade também colabora para que as iniciativas para a solução do problema sejam assumidas por pessoas até bem intencionadas, porém de forma amadora.

Nos Estados Unidos, duas organizações internacionais de reabilitação de vida silvestre, a Associação Nacional de Reabilitação de Vida Silvestre em Minnesota, e o Conselho Internacional de Reabilitação de Vida Silvestre na Califórnia têm trabalhado para padronizar e responsabilizar os mantenedores de animais. Elas empregam um código de ética contendo um guia com as dimensões dos recintos para os animais, procedimentos médicos, condutas e guia de nutrição apropriado para auxiliar na reabilitação (JIMÉNEZ-PÉREZ, 1999).

As metas visam assegurar que os animais recebam atenção adequada para maximizar as oportunidades de retorno para o meio silvestre. "Ainda que algumas das recomendações para as instalações e os cuidados veterinários estão fora do alcance dos meios de muitos reabilitadores, representam padrões que os reabilitadores podem e devem tratar de alcançar" (a tradução é nossa) (CLARK JR., 1999, p. 100).

Para o Brasil, é muito importante que as práticas adotadas nos países da América do Sul sejam discutidas, uma vez que o comércio ilegal da fauna silvestre é um problema comum no País e envolve uma fauna bastante semelhante, quando não pertencentes às mesmas espécies. 


\subsubsection{Centros Nacionais de Recepção de Fauna}

No Brasil, os centros são supervisionados pelo IBAMA por meio de termos de cooperação técnica, e normalmente pertencem a jardins zoológicos, empresas privadas, instituições acadêmicas e ONGs, a exemplo do que ocorre na Região Neotropical, não sendo objeto do presente estudo. São raros os centros ligados a órgãos de governo.

O IBAMA reconhece que se trata de empreendimento oneroso e que lida diretamente com vida, sendo que as suas atividades não podem ser interrompidas repentinamente por falta de recursos.

Não obstante a importância e necessidade da existência de centros para recepcionar animais, principalmente vitimados pelo tráfico, até 2007 não existia qualquer instrumento ou norma infra-legal que regulamentasse a atividade, e desse os requisitos quanto às instalações, equipamentos e pessoal necessários.

Segundo LO (2004), não existe legislação específica que cria e regulamenta a figura dos CETAS, reconhecendo a necessidade de normatização, por se tratar de um serviço bastante distinto dos criadouros, zoológicos e mantenedores de fauna.

Até então, para o IBAMA (2008), o CETAS era um local com a finalidade de recepcionar, triar e tratar os animais silvestres resgatados ou apreendidos pelos órgãos fiscalizadores, assim como eventualmente, receber animais silvestres de particulares que os estavam mantendo em cativeiro domésticos de forma irregular como animais de estimação.

Em 21 de fevereiro de 2008, o IBAMA publica a Instrução Normativa - IN 169/2008 ${ }^{14}$, onde consta:

"Art. $1^{\circ}$ Instituir e normatizar as categorias de uso e manejo da fauna silvestre em cativeiro em território brasileiro, visando atender às finalidades socioculturais, de pesquisa científica, de conservação, de exposição, de manutenção, de criação, de reprodução, de comercialização, de abate e de beneficiamento de produtos e

\footnotetext{
${ }^{14}$ IBAMA - IN 169 de 20 de fevereiro de 2008, publicada no Diário Oficial da União, Brasília, DF, 21 fev. 2008, Seção 1, nº 35, p. 57.
} 
subprodutos, constantes do Cadastro Técnico Federal (CTF) de Atividades Potencialmente Poluidoras ou Utilizadoras de Recursos Naturais.

I- jardim zoológico;

II- centro de triagem (o destaque é nosso);

III- centro de reabilitação (o destaque é nosso);

IV- mantenedor de fauna silvestre;

$\mathrm{V}$ - criadouro científico de fauna silvestre para fins de pesquisa;

VI- criadouro científico de fauna silvestre para fins de conservação;

VII- criadouro comercial de fauna silvestre;

VIII- estabelecimento comercial de fauna silvestre;

IX- abatedouro e frigorífico de fauna silvestre".

Com essa Instrução Normativa, o IBAMA passa a reconhecer tanto a existência dos centros de triagem, como dos centros de reabilitação de animais silvestres, dando as seguintes definições:

Inciso "VII - Centro de reabilitação de animais silvestres (CRAS): todo empreendimento autorizado pelo Ibama, somente de pessoa jurídica, com finalidade de: receber, identificar, marcar, triar, avaliar, recuperar, criar, recriar, reproduzir, manter e reabilitar espécimes da fauna silvestre nativa para fins de programas de reintrodução no ambiente natural;".

Inciso "VIII - Centro de triagem de animais silvestres (CETAS): todo empreendimento autorizado pelo Ibama, somente de pessoa jurídica, com finalidade de: receber, identificar, marcar, triar, avaliar, recuperar, reabilitar e destinar animais silvestres provenientes da ação da fiscalização, resgates ou entrega voluntária de particulares;".

Pela referida Instrução Normativa, o centro de reabilitação também tem por finalidades criar, recriar e até reproduzir espécimes da fauna, finalidades essas atribuídas aos criadouros científicos para fins de pesquisa ou conservação; enquanto que o centro de triagem também tem a finalidade de reabilitar os animais.

Dessa forma, essa instrução normativa não distingue as atribuições específicas das diferentes categorias das entidades autorizadas a efetuar o uso e manejo da fauna 
silvestre em cativeiro em território brasileiro, e se torna inócua. Também não disciplina a recolocação de animais na natureza, conforme prioriza a legislação, e não especifica para onde devem ser destinados os animais apreendidos.

Apesar de apenas em 2008 ter sido publicada uma instrução normativa que reconhece as figuras do CRAS e do CETAS, o Estado do Mato Grosso possui um Centro de Reabilitação de Animais Silvestres (CRAS), que opera desde julho de 1988, no Município de Campo Grande.

Atualmente, o CRAS de Campo Grande está subordinado ao Instituto do Meio Ambiente do Estado do Mato Grosso do Sul - IMASUL, entidade pública integrante da administração indireta da Secretaria de Estado do Meio Ambiente, das Cidades, do Planejamento, da Ciência e Tecnologia - SEMAC (SEMAC, 2008). O IMASUL possui natureza autárquica, a quem compete, segundo o Decreto $\mathrm{n}^{\circ} 12.231$, de 3 de janeiro de 2007, artigo 19, inciso III - executar as ações pertinentes à operacionalização do Centro de Reabilitação de Animais Silvestres (CRAS), através da Gerência de Recursos Pesqueiros e da Fauna.

Segundo SANTOS e LOPES (2006, p. 11), o CRAS de Mato Grosso do Sul tem como atribuições a recepção, triagem, reabilitação e destinação de animais nativos, apreendidos durante ações de fiscalização, atropelados ou doados pela população, bem como propor e executar ações que visem à conservação da fauna nativa no seu hábitat natural, em todo o Estado. Desde a sua criação foram recepcionados cerca de 20.000 espécimes, com uma média anual de 1.100 animais, que foram destinados para zoológicos, criadouros e soltura na natureza.

Ainda, segundo os autores, nesse CRAS as destinações são classificadas como:

- Soltura direta: onde a devolução é realizada após triagem e soltura em local onde a espécie está presente;

- Soltura monitorada: onde a soltura é realizada após curto período de cativeiro;

- Atendimento a projetos de conservação da espécie, com o encaminhamento para instituições de pesquisa e zoológicos, mediante consulta ao respectivo comitê, quando existente. 
No Centro, que conta com uma equipe de 15 funcionários (IMASUL, 2008), são atendidos principalmente animais apreendidos do tráfico e da manutenção ilegal em cativeiro. As solturas são realizadas em áreas cadastradas, com qualidade ambiental e finalidade de repovoamento, onde ocorre a espécie e não apresenta pressão da caça.

A partir de 2005, o CRAS está atuando principalmente em propriedades que têm atividades de ecoturismo e um compromisso com a conservação ambiental. Os proprietários passam a atuar como parceiros nos programas de soltura dos animais reabilitados, (...). Em troca, os animais silvestres soltos pelo CRAS tornam-se um atrativo turístico importante nesses locais (grifo nosso) (SANTOS e LOPES, 2006, p. 12).

Com relação à sobrevivência dos animais após a soltura, foi constado que a principal causa de mortes está relacionada ao comportamento agressivo entre eles, com poucos relatos sobre ataques de predadores selvagens. Devido ao grau de dependência do homem, os animais procuram alimentação e abrigo nas proximidades das habitações, o que demonstra a importância do envolvimento dos proprietários e funcionários das fazendas utilizadas como áreas de soltura, para o sucesso dessa prática.

Segundo LO (2004), no Estado de São Paulo, de acordo com a Superintendência do IBAMA no Estado, há quatro CETAS governamentais, sendo três deles localizados na Capital. Esses centros são:

1. CETAS de Lorena, localizado no município de Lorena e que é administrado pelo próprio IBAMA;

2. Centro de Recuperação de Animais Silvestres - CRAS, gerenciado pelo Departamento de Água e Energia da Secretaria de Recursos Hídricos do Governo do Estado de São Paulo;

3. Divisão Técnica de Medicina Veterinária e Manejo da Fauna Silvestre (DEPAVE-3), pertencente à Secretaria Municipal do Verde e do Meio Ambiente; 
4. Centro de Manejo de Animais Silvestres (CEMAS), subordinado à Fundação Parque Zoológico de São Paulo, vinculada à Secretaria do Meio Ambiente do Governo do Estado de São Paulo.

Nota-se, que o IBAMA também denomina de CETAS serviços de fauna pertencentes a outros órgãos ambientais das esferas estadual e municipal, pelo fato de também recepcionarem animais silvestres apreendidos e resgatados.

Dentre os quatro CETAS existentes no Estado, apenas o de Lorena tem assinado o Termo de Cooperação Técnica com o IBAMA (LO, 2004).

Em São Paulo, no final da década de 1980, começou a operar o primeiro CETAS do Estado no Parque Ecológico Engenheiro Goulart, do Departamento de Águas e Energia Elétrica (DAEE), uma autarquia vinculada à Secretaria de Energia, Recursos Hídricos e Saneamento do Governo do Estado de São Paulo. Atualmente, ele é denominado Centro de Recuperação de Animais Silvestres do Parque Ecológico do Tietê (CRAS-PET).

Segundo MILANETO (2006, p. 36), o centro recebe na sua maioria animais oriundos do tráfico de animais silvestres em quantidade crescente ao longo dos vinte anos de existência, "indicando uma maior ação por meio dos órgãos fiscalizadores, bem como reflexo do aumento da captura dos animais no meio ambiente".

De acordo com SMA (1999), existe a necessidade de definição e estruturação de centros de triagem para as instituições que apreendem animais, pelo conteúdo das seguintes falas em um seminário promovido pela Secretaria de Estado do Meio Ambiente:

A representante do IBAMA ${ }^{15}$, afirma: “... não existe legislação específica, algo que normatize os Centros de Triagem, embora tenhamos toda a legislação de criadouros e de zoológicos" (p. 23).

..."Nós estamos estudando alguns critérios básicos para centros de triagem, dentro de um projeto básico, elaborado em etapas, inclusive levando em consideração os

\footnotetext{
${ }^{15}$ Marli Carbonari, da Diretoria de Ecossistemas (DIREC) IBAMA-SP, integrante da Mesa Redonda: Centros de Recepção e Triagem (CETAS), realizada durante o Seminário Sistemas de Recepção, Manejo e Destinação de Animais Silvestres, promovido pela Secretaria de Estado do Meio Ambiente.
} 
custos - que é claro não vão entrar na legislação, mas podem embasar - para que seja enviada para Brasília uma proposta viável” (p. 24).

"Recebemos apreensões periódicas e não temos como estar destinando estes animais" (p. 23).

Os centros de recepção e triagem são necessários sim, pois precisamos de um local para levar os animais. No IBAMA, por exemplo, se chega uma apreensão de duas mil aves, você não tem onde colocar, e nem para identificar, quer dizer, poderíamos estar fazendo a identificação, temos o técnico disponível, mas não dá para fazer a identificação de um animal na garagem do prédio e quem trabalha com fauna sabe da dificuldade de identificar subespécies regionais, e para isto é preciso um local adequado (p. 23).

Dando prosseguimento, no debate da plenária são registradas as seguintes falas:

SMA (1999) "O nome talvez não devesse ser Centro de Triagem, mas sim núcleo de quarentena de animais silvestres, o que não referendaria um grande depósito, mas sim uma quarentena até que o animal fosse para seu lugar definitivo." (p. 28).

“A base do funcionamento do Centro de Triagem é a pesquisa de campo.”(p. 29).

"Os zoológicos não são "depósito de bichos. ... O zoológico não é um Centro de Triagem, é um receptor e o bicho fica. ... A função do Zoológico não é receber estes animais ou funcionar como depósito, mas tem recebido até pra desafogar um pouco os outros órgãos." ( p. 29).

Nestas falas, fica explícita a necessidade de institucionalização de locais para o recebimento de animais vitimados, porém com parâmetros norteadores para o seu funcionamento. Existe a preocupação com os custos para a implantação e operação dos serviços, devido à complexidade dos trabalhos que nele devem ser realizados. Percebese, também, certa indefinição quanto ao nome e à missão do centro, principalmente quando é sugerido o nome de núcleo de quarentena, ou que a base de funcionamento do centro deva ser a pesquisa de campo.

O importante é que animais silvestres tenham locais apropriados para recebê-los e dar-lhes a devida destinação, levando-se em consideração as peculiaridades e necessidades das espécies. Dessa forma, não basta construir alguns recintos para o 
alojamento de animais vitimados, mas sim, uma estrutura que atenda todas as etapas do processo, desde o recebimento dos animais até a sua destinação final, contando com pessoal qualificado e equipamentos necessários para o desenvolvimento de todas as atividades que possibilitem que os animais sejam recolocados na natureza, conforme prioriza a legislação.

Nesse sentido, SÃO PAULO (Estado), (2000) instituiu o Programa de Proteção à Fauna Silvestre do Estado de São Paulo, gerenciado por um grupo composto por representantes de diversas unidades da Secretaria de Estado do Meio Ambiente com atribuições voltadas à fauna. O grupo ficou incumbido, entre outras responsabilidades, da implantação do "Projeto Centro de Manejo, Reabilitação e Triagem de Animais Silvestres no Parque Estadual Alberto Loefgreen" (CEMAS) ${ }^{16}$, na Serra da Cantareira, Cidade de São Paulo.

Em 2003 o CEMAS assume a finalidade de possibilitar a reabilitação, a adaptação e a reinserção no hábitat natural de animais silvestres apreendidos ou resgatados que ocorrem no Estado de São Paulo, prioritariamente os ameaçados de extinção (VIO, 2004), diferentemente de sua concepção onde seriam atendidos os animais vitimados do Estado, independente de estarem ou não ameaçados de extinção.

Segundo o Decreto Estadual no 42.838, de 4 de fevereiro de 1998, o Estado de São Paulo possui 526 espécies animais comprometidas no processo de extinção. Na lista, 313 encontram-se ameaçadas de extinção (destas, 25 foram consideradas provavelmente extintas) e 213 tidas como provavelmente ameaçadas (GOVERNO DO ESTADO DE SÃO PAULO, 1998).

Para Clark et al. e Snyder et al., citados por JIMÉNEZ-PÉREZ (1999, p. 79), projetos que têm conseguido superar os obstáculos devem assegurar sua continuidade e coerência ao longo do tempo, o que depende do grau de preparação e dedicação das pessoas por eles encarregadas, e da manutenção de uma política coerente. Infelizmente, as instituições envolvidas nessas iniciativas enfrentam normalmente a troca de pessoal, baixa prioridade orçamentária, problemas de cooperação entre instituições e mudanças bruscas na política.

\footnotetext{
${ }^{16}$ SMA- Processo n $42.637 / 99$ - Implantação do Projeto CEMAS.
} 


\section{POLÍtica PÚblica bRASIleira e A GeSTÃo dA FAUNA SILVESTRE NATIVA}

As normas constitucionais e legais aplicáveis à matéria fauna, tratam de sua conceituação, sua propriedade, dos deveres e responsabilidades das pessoas físicas e jurídicas de direito público ou privado. A fauna é considerada um recurso ambiental, sendo um bem integrante do meio ambiente.

O meio ambiente, de acordo com o artigo $3^{\circ}$, inciso I, da Lei Federal $n^{\circ} 6.938 / 81$, "é o conjunto de condições, leis, influências, alterações e interações de ordem física, química e biológica, que permite, abriga e rege a vida em todas as suas formas".

Os textos jurídicos sobre a fauna geralmente estão inseridos no Capítulo do Meio Ambiente e definem como crime as práticas contrárias às disposições legais e protecionais. Os textos nem sempre diferenciam as espécies e categorias de animais, referindo-se indistintamente a todos os animais.

MACHADO (1991, p. 398), define como fauna "o conjunto de espécies animais de um determinado país ou região".

De acordo com a classificação legal, os animais são divididos em espécies da fauna silvestre nativa ou exótica, domésticos ou domesticados. Conforme artigo $29 \S 3^{\circ}$ da Lei Federal n 9.605/98, "são espécimes da fauna silvestre todos aqueles pertencentes às espécies nativas, migratória e quaisquer outras, aquáticas ou terrestres, que tenham todo ou parte de seu ciclo de vida ocorrendo dentro dos limites do território brasileiro, ou águas jurisdicionais brasileiras”.

A fauna silvestre exótica compreende as espécies nativas que não ocorrem dentro dos limites do território brasileiro, ou águas jurisdicionais brasileiras, enquanto que a fauna doméstica é constituída pelas espécies que, ao longo de um lento processo evolutivo e "através de processos tradicionais de manejo, passaram a ter características biológicas e comportamentais com estreita dependência do homem" (LEVAY, 2004, p. $34)$. 
Essa classificação é de extrema importância, pois irá nortear a aplicação das sanções dos crimes contra a fauna, o destino dos animais vitimados, bem como as práticas de manejo que deverão ser adotadas para as diferentes categorias e espécies.

Para o entendimento de como a fauna está contemplada na constituição brasileira e normas infra-constitucionais, a transcrição de alguns artigos da legislação revela a sua importância e a responsabilidade do governo e da sociedade civil por sua proteção:

\section{Constituição da República Federativa do Brasil}

\section{CAPÍTULO VI - Do Meio Ambiente}

Art. 225. Todos têm direito ao meio ambiente ecologicamente equilibrado, bem de uso comum do povo e essencial à sadia qualidade de vida, impondo-se ao Poder Público e à coletividade o dever de defendê-lo e preservá-lo para as presentes e futuras gerações.

$\$ 1^{\circ}$ Para assegurar a efetividade desse direito, incumbe ao Poder Público:

VII - proteger a fauna e a flora, vedadas, na forma da lei, as práticas que coloquem em risco sua função ecológica, provoquem a extinção de espécies ou submetam os animais à crueldade.

\section{CAPÍTULO I - Da Organização Político-Administrativa}

Art. 23. É competência comum da União, dos Estados, do Distrito Federal e dos Municípios:

VII - preservar as florestas, a fauna e a flora; (...)

Art. 24. Compete à União, aos Estados e ao Distrito Federal legislar concorrentemente sobre:

VI - florestas, caça, pesca, fauna, conservação da natureza, defesa do solo e dos recursos naturais, proteção do meio ambiente e controle da poluição; (...)

Art. 30. Compete aos Municípios:

I - legislar sobre assuntos de interesse local;

\section{Decreto $n^{0}$ 24.645, de 10 de julho de 1934}

Estabelece Medidas de Proteção aos Animais

Art. $1^{\circ}$ Todos os animais existentes no País são tutelados do Estado. 


\section{Lei $n^{0}$ 5.197, de 3 de janeiro de 1967}

Dispõe sobre a Proteção à Fauna, e dá outras providências.

Art. $1^{\circ}$ Os animais de quaisquer espécies, em qualquer fase do seu desenvolvimento e que vivem naturalmente fora do cativeiro, constituindo a fauna silvestre, bem como seus ninhos, abrigos e criadouros naturais, são propriedade do Estado, sendo proibido a sua utilização, perseguição, destruição, caça ou apanha.

Art. $2^{\circ}$ É proibido o exercício da caça profissional.

\section{Lei $n^{\circ}$ 9.605, de 12 de fevereiro de 1998}

Dispõe sobre as sanções penais e administrativas derivadas de condutas e atividades lesivas ao meio ambiente, e da outras providências.

Art. 25. Verificada a infração, serão apreendidas seus produtos e instrumentos, lavrandose os respectivos autos.

$\S 1^{\circ}$ Os animais serão libertados em seu habitat ou entregues a jardins zoológicos, fundações ou entidades assemelhadas, desde que fiquem sob a responsabilidade de técnicos habilitados.

\section{SEÇÃO I - Dos crimes contra a Fauna}

Art. 29. Matar, perseguir, caçar, apanhar, utilizar espécimes da fauna silvestre, nativos ou em rota migratória, sem a devida permissão, licença ou autorização da autoridade competente, ou em desacordo com a obtida: (...)

Art. 32. Praticar ato de abuso, maus tratos, ferir ou mutilar animais silvestres, domésticos ou domesticados, nativos ou exóticos: (...).

\section{Decreto $\mathrm{n}^{\circ}$ 97.946, de 11 de julho de 1989}

Dispõe sobre a Estrutura Básica do Instituto Brasileiro do Meio Ambiente e dos Recursos Naturais Renováveis - IBAMA, e dá outras providências.

Art. 17. O Conselho Nacional de Proteção à Fauna, criado pelo Decreto n ${ }^{\circ}$ 97.633, de 10 de abril de 1989, tem por finalidade estudar e propor diretrizes para a proteção e manejo da fauna. 


\section{Constituição do Estado de São Paulo}

CAPÍTULO IV - Do Meio Ambiente, dos Recursos Naturais e do Saneamento

$$
\text { SEÇÃO I - Do Meio Ambiente }
$$

Art. 193. O Estado, mediante lei, criará um sistema de administração da qualidade ambiental, proteção, controle e desenvolvimento do meio ambiente e uso adequado dos recursos naturais, para organizar, coordenar e integrar as ações de órgãos e entidades da administração pública direta e indireta, assegurada a participação da coletividade, com o fim de:

I - propor uma política estadual de proteção ao meio ambiente; (...)

$\mathrm{X}$ - proteger a flora e a fauna, nesta compreendidos todos os animais silvestres, exóticos e domésticos, vedadas as práticas que coloquem em risco sua função ecológica e que provoquem extinção de espécies ou submetam os animais à crueldade, fiscalizando a extração, produção, criação, métodos de abate, transporte, comercialização e consumo de seus espécimes e subprodutos; (...)

Art. 204 - Fica proibida a caça, sob qualquer pretexto, em todo o Estado.

\section{Lei Estadual no 11.977, de 25 de agosto de 2005}

Artigo $1^{\circ}$ Institui o Código Estadual de Proteção aos Animais, estabelecendo normas para a proteção, defesa e preservação dos animais no Estado.

\section{Seção I}

Programa de Proteção à Fauna Silvestre

Artigo $6^{\circ}$ - Fica instituído o Programa de Proteção à Fauna Silvestre do Estado.

$\S 1^{\circ}$ Todos os Municípios do Estado, por meio de projetos específicos, deverão:

1. atender às exigências legais de proteção à fauna silvestre;

2. promover a integração dos serviços de normatização, fiscalização e de manejo da fauna silvestre do Estado;

3. promover o inventário da fauna local;

4. promover parcerias e convênios com universidades, ONGs e iniciativa privada;

5. elaborar planos de manejo de fauna, principalmente para as espécies ameaçadas de extinção; 
6. colaborar no combate ao tráfico de animais silvestres;

7. colaborar na rede mundial de conservação.

$\S 2^{\circ}$ - Todos os Municípios do Estado poderão viabilizar a implantação de Centros de Manejo de Animais Silvestres, para:

1. atender, prioritariamente, os animais silvestres vitimados da região;

2. prestar atendimento médico-veterinário e acompanhamento biológico aos animais silvestres;

3. dar apoio aos órgãos de fiscalização no combate ao comércio ilegal e demais infrações cometidas contra os animais silvestres;

4. promover estudos e pesquisas relativos à fauna silvestre e meio ambiente;

5. promover ações educativas e de conscientização ambiental.

Artigo $7^{\circ}$ A Administração Pública Estadual, através de órgão competente, publicará a cada 4 (quatro) anos a lista atualizada de Espécies da Fauna Silvestre Ameaçadas de Extinção e as Provavelmente Ameaçadas de Extinção no Estado, e subsidiará campanhas educativas visando sua divulgação e preservação.

Do ponto de vista legal, tanto a Constituição Federal quanto as diversas normas infra-constitucionais deixam explícitas as competências e responsabilidades, tanto dos governos quanto dos cidadãos, pelos cuidados para com a natureza e a fauna nela inserida.

Todos os animais são tutelados pelo Estado e a fauna silvestre é propriedade do Estado, remetendo a ele, a obrigação de zelar por todos os espécimes, e não simplesmente aplicar medidas voltadas à proteção das espécies.

Algumas iniciativas de governos estaduais traduzem em suas Constituições o compromisso pelo bom trato das questões ambientais, com aprimoramento no compromisso de sua defesa, como a Constituição Paulista que proíbe a caça, em todas as suas modalidades, mesmo comprometendo as práticas de manejo que dela possam depender.

Também em São Paulo, está parcialmente em vigor o Código Estadual de Proteção aos Animais com um conteúdo bastante protecionista quando trata de questões 
pertinentes aos animais domésticos, causando alguns problemas para os pecuaristas; enquanto que, com relação aos silvestres, assume o compromisso de sua proteção e defesa, institucionalizando um programa específico para esta finalidade.

Nesse Código, está previsto que os Municípios do Estado poderão viabilizar a implantação de Centros de Manejo de Animais Silvestres, visando prioritariamente os animais vitimados da região, devendo dispor de estrutura compatível à complexidade dos trabalhos, que também deverão estar voltados à pesquisa e educação ambiental.

Pela análise da legislação e segundo um parecer jurídico de CUSTÓDIO $^{17}$, podemos afirmar que:

... os animais silvestres, além de pertencerem ao domínio público, integram o próprio patrimônio público do Estado, ou seja, todas as Unidades da Federação responsáveis pela sua diligente administração, pela sua defesa ou proteção e pela sua preservação vinculada à função ecológica, no âmbito dos respectivos territórios e das respectivas e harmônicas competências, pois se trata de bens públicos destinados ao uso comum do povo.

\subsection{COMPETÊNCIA DOS MUNICÍPIOS NA GESTÃO AMBIENTAL}

DALLARI (2003) observa que no artigo 23 da Constituição da República Federativa do Brasil, Municípios, Estados e Distrito Federal têm responsabilidades comuns.

Modernamente, tornou-se comum a atribuição de competências concorrentes, ou seja, outorga de competência à União e às unidades federadas para cuidarem do mesmo assunto (...). Assim sendo, quando se tratar de assuntos de competência de uma unidade federada, esta é que pode legislar sobre o assunto, não a União, e vice-versa (DALLARI, 2003, p. 258-259).

\footnotetext{
${ }^{17}$ Helita Barreiro Custódio. Crueldade contra animais e a proteção destes como relevante questão jurídicoambiental e constitucional. Parecer Jurídico. São Paulo, 1997. p. 5.
} 
Já o artigo 30 da Constituição, dispõe sobre a competência do Município de legislar sobre tudo que diz respeito ao interesse local, e nesse sentido, a proteção do meio ambiente é de interesse local.

PHILIPPI JR. et al. (1996), destaca que antes da referida Constituição, a Lei Federal $n^{\circ}$ 6.938/81, que estabeleceu a Política Nacional do Meio Ambiente, criou o Ministério do Meio Ambiente, dos Recursos Hídricos e da Amazônia Legal, atualmente, Ministério do Meio Ambiente, e também o Sistema Nacional do Meio Ambiente (SISNAMA).

Segundo o artigo $6^{\circ}$ da Lei 6.938 - "Os órgãos e entidades da União, dos Estados, do Distrito Federal, dos territórios e dos Municípios, bem como as Fundações instituídas pelo Poder Público, responsáveis pela proteção e melhoria da qualidade ambiental, constituirão o Sistema Nacional do Meio Ambiente - SISNAMA, assim estruturado: (Órgão Superior, Central, Setoriais, Seccionais e Locais)".

O inciso V - especifica como Órgãos Locais, “os órgãos ou entidades municipais responsáveis pelo controle e fiscalização dessas atividades, nas suas respectivas áreas de jurisdição".

O Art. 20 traz as exigências para que os entes federados possam exercer suas competências licenciatórias devendo implementar os Conselhos de Meio Ambiente, com caráter deliberativo e participação social e, ainda, possuir em seus quadros ou a sua disposição profissionais legalmente habilitados.

Assim, para que as unidades federadas possam legislar e assumir as responsabilidades referentes às questões ambientais, necessariamente precisam estar integradas ao SISNAMA, por meio de um órgão executivo e de um Conselho de Meio Ambiente, na respectiva esfera de governo.

Com relação ao Estado de São Paulo, a Constituição de 05 de outubro de 1989 incorpora as questões ambientais, até então enfrentadas pela Secretaria de Estado do Meio Ambiente (SMA), criada em 1986, que possui um órgão colegiado de caráter consultivo e deliberativo, o Conselho Estadual do Meio Ambiente (CONSEMA).

Na esfera do Município de São Paulo, em 18 de outubro de 1993, foi instituído pela Lei Municipal $\mathrm{n}^{\circ}$ 11.426, o Sistema Municipal de Meio Ambiente (SISMMA), 
composto pela Secretaria Municipal do Verde e do Meio Ambiente (SVMA) e pelo Conselho Municipal de Meio Ambiente e Desenvolvimento Sustentável (CADES) (SÃO PAULO (Município), 1993).

Entre as atribuições da SVMA destacam-se o planejamento, o ordenamento e a coordenação das atividades de defesa do meio ambiente, no âmbito do Município de São Paulo (SVMA, 1997).

Ao CADES cabe o papel de órgão consultivo e deliberativo voltado às questões ambientais no território municipal. É composto por trinta Conselheiros que representam o Poder Público (União, Estado e Município) e a sociedade civil por meio de representantes das Universidades, Movimento Sindical, Indústria e Comércio, Entidades Profissionais, e a Câmara Municipal.

Dessa forma, grande parte das realizações da Prefeitura de São Paulo na área ambiental deve-se a criação da SVMA e do CADES, integrando o município no SISNAMA e garantindo maior autonomia na gestão ambiental de seu território.

Também, a Conferência das Nações Unidas e Desenvolvimento Sustentável (CONUMAD), conhecida por Eco-92, trouxe uma importante contribuição para os governos locais, a Agenda 21, um programa de ação que viabiliza um novo padrão de desenvolvimento ambientalmente racional. Com 175 países signatários, visa estabelecer um plano de ações concretas para melhorar a qualidade de vida e do meio ambiente, dando uma ênfase especial à participação do poder local, no planejamento, fiscalização e implementação de mudanças necessárias para atingir esses objetivos, gradativamente em escala global.

O capítulo 28 da Agenda 21 Global estabelece que "cada autoridade em cada país implemente uma Agenda 21 Local, tendo como base de ação a construção, operacionalização e manutenção da infra-estrutura econômica, social e ambiental local, estabelecendo políticas ambientais locais e prestando assistência na implementação de políticas ambientais nacionais" (MMA, 2005).

Portanto, a Constituição Federal de 1988 que "consagrou o princípio da descentralização política e da municipalização", apresenta uma consonância direta com a Agenda 21 e suas metas, por privilegiar a ação local, delegando aos municípios "e, 
portanto, aos cidadãos", a tarefa de dizer como aspiram o desenvolvimento e o futuro da sua localidade, bem como inspira a criação dos instrumentos para implantação desta nova gestão (CEPAM, 2001).

No que tange a fauna silvestre, a Lei Orgânica do Município de São Paulo de 1990, em seu Capítulo V - Do Meio Ambiente define que:

Art. 180 - O Município, em cooperação com o Estado e a União, promoverá a preservação, conservação, defesa, recuperação e melhoria do meio ambiente.

Art. 186 - O Município deverá recuperar e promover o aumento de áreas públicas para implantação, preservação e ampliação de áreas verdes, inclusive arborização frutífera e fomentadora da avifauna.

Art. 188. O Município coibirá o tráfico de animais silvestres, exóticos e de seus subprodutos e sua manutenção em locais inadequados, bem como protegerá a fauna local e migratória do Município de São Paulo, nesta compreendidos todos os animais silvestres ou domésticos, nativos ou exóticos.

$\S 1^{\circ}$ Ficam proibidos os eventos, espetáculos, atos públicos ou privados, que envolvam maus tratos e crueldade de animais, assim como as práticas que possam ameaçar de extinção, no âmbito deste Município, as espécies da fauna local e migratória.

Portanto, a lei orgânica da Cidade de São Paulo incorpora integralmente o espírito de preservação, conservação e proteção da fauna quando se incumbe de recuperar o meio ambiente, coibir o tráfico de animais e proibir práticas que envolvam maus tratos a qualquer espécie de animal, ou ameaça de extinção dos silvestres.

Norteada pela Lei Orgânica do Município e pela estrutura da SVMA, no Município de São Paulo foi promulgada a seguinte lei:

Lei Municipal n 12.055, de 09 de maio de 1996 (anexo 1).

Autoriza a implantação do Centro de Reabilitação de Animais Silvestres - CRAS e o Centro de Triagem de Animais Silvestres - CETAS, como Seções Técnicas do DEPAVE-3: 
Art. $1^{\mathrm{o}}$ Fica o Executivo autorizado a implantar, no Parque Anhanguera, o Centro de Triagem de Animais Silvestres (CETAS) e o Centro de Reabilitação de Animais Silvestres (CRAS).

Parágrafo único: O CETAS e o CRAS ficam subordinados à Divisão Técnica de Medicina Veterinária e Biologia da Fauna (DEPAVE-3), do Departamento de Parques e Áreas Verdes DEPAVE, da Secretaria do Verde e do Meio Ambiente - SVMA (SÃO PAULO (Município), 1996).

Essa lei foi regulamentada pelo Decreto Municipal $\mathrm{n}^{\circ} 37.653$, de 25 de setembro de 1998 (SÃO PAULO (Município), 1998) (anexo 2).

Com a promulgação e regulamentação dessa lei, única no país que cria centros voltados à reabilitação e triagem de animais silvestres, e integrando-os ao DEPAVE-3, o município assume integralmente a gestão da fauna em seu território, por meio de políticas públicas voltadas aos animais silvestres, geridas pelo órgão gestor de meio ambiente da cidade, em consonância com o SISNAMA.

Segundo CLARK JR. (1999 p. 92), a efetividade das leis dependem na maioria dos casos dos recursos, das instituições governamentais e seus dirigentes, assim como de seus desejos políticos de fazer cumprir as leis. Normalmente, as instituições resistem a novas políticas e são reticentes a apoiar novas maneiras de fazer as coisas. "A esse respeito, a conservação efetiva depende muitas vezes tanto da habilidade política dos conservacionistas, como de sua capacidade e experiência científica".

Muitas nações têm promulgado leis estritas mudando o tratamento oferecido aos animais, e mesmo considerado o interesse científico por trás dessas iniciativas, "elas representam um marco ético evolutivo que está redefinindo nossas relações com os animais, e especialmente com a vida silvestre" (o destaque é nosso) (a tradução é nossa) (CLARK JR., 1999, p. 94).

A importância de um município ou estado assumir seus compromissos frente aos animais vitimados, reside no fato de que os animais são resgatados nas cidades e 
necessitam receber assistência médica, alimentação e alojamento com máxima urgência, não podendo aguardar que essas providências venham da União. Os recursos necessários para a implantação e operação dos serviços de fauna podem ser provenientes de outras esferas de governo, bem como da iniciativa privada, porém, as ações devem ser realizadas no nível local. Também deve ser considerado que, quando pessoas sensibilizadas com o sofrimento dos animais os socorrem e os domiciliam, estão infringindo a legislação e poderão sofrer as sanções legais nela prevista. 


\section{APRESENTAÇÃO DO CASO ESTUDADO}

\subsection{CARACTERIZAÇÃO AMBIENTAL DO MUNICÍPIO DE SÃO PAULO ${ }^{18,19}$}

São Paulo é a maior cidade da América do Sul, com uma área de $1.523 \mathrm{Km}^{2} \mathrm{e}$ população estimada de 10.886 .518 habitantes, em 2007.

A cobertura vegetal natural é constituída basicamente por fragmentos de Mata Atlântica Secundária no extremo norte e sul da cidade, que está instalada onde originariamente a vegetação era constituída basicamente por várzeas, campos e florestas.

Com a expansão da cultura cafeeira nos meados do século XIX, a maior parte da cobertura florestal foi devastada, e no início do século XX, extensas regiões ao Sul, cobertas por vegetação nativa, foram ocupadas pela construção das Represas Billings e Guarapiranga, com a finalidade de geração de energia elétrica e abastecimento público de água. Com o declínio dessa cultura, muitas áreas foram posteriormente utilizadas para outras atividades agrícolas e pecuária, enquanto que em locais menos habitados e de difícil acesso, o abandono das lavouras de café propiciou o restabelecimento de vegetação natural secundária, que hoje constitui a maior parte da cobertura florestal existente.

A partir da década de 1940, a cidade consolida-se como uma metrópole industrial e inicia o processo de periferização. Na década de 1970, a concentração de renda se intensifica e o crescimento da cidade cria novos bairros e intensifica a favelização que avança sobre a cobertura vegetal, tanto em áreas públicas como privadas, onde os loteamentos irregulares, bem como a poluição das águas e supressão da vegetação, atingem os remanescentes de Mata Atlântica e sua rica biodiversidade.

\footnotetext{
${ }^{18}$ PMSP. Secretaria Municipal do Verde e do Meio Ambiente. ICLEI (Internacional Council for Local Environmental Iniciatives). LAB. Local Action for Biodiversitu of São Paulo City (2008). No prelo.

${ }^{19}$ CDB - Convention on Biological Diversity. City of São Paulo, Brazil. Quebéc, 2008. Disponível em: $<$ https://www.cbd.int/authorities/casestudy/saopaulo.shtml>. Acesso em: 22 fev. 2008.
} 
Em 2002, a Lei Municipal no 13.430/02 institui o novo Plano Diretor da Cidade de São Paulo, que constitui o documento legal ordenador das políticas de desenvolvimento urbano, econômico e social, bem como, um marco regulador do uso do solo. O grande avanço desta lei foi a incorporação da dimensão ambiental no trato das políticas urbanas da cidade, marcadas tradicionalmente por uma visão predominantemente urbanística. O território municipal passa a ser dividido em duas macrozonas: Macrozona de Proteção Ambiental e Macrozona de Estruturação e Qualificação Urbana.

A definição da Macrozona de Proteção Ambiental, que corresponde a cerca de $1 / 3$ do território paulistano, demonstra a necessidade de preservar, conservar ou recuperar o ambiente natural.

A lógica do crescimento de São Paulo foi cruel do ponto de vista humano, atraindo e segregando parcelas enormes de população, enquanto que a fauna silvestre também sofria com o processo de degradação ambiental.

Dentre os problemas que comprometem de forma mais contundente a qualidade de vida urbana estão: a carência de áreas verdes; a impermeabilidade excessiva do solo; a ocupação de várzeas, encostas e mananciais; as condições precárias de esgotamento sanitário; destinação e tratamento de resíduos; a contaminação ambiental, além de todas as formas de poluição. Por outro lado, $21 \%$ do município é coberto por maciços florestais em diversos estágios de sucessão ecológica, altamente ameaçados pela ocupação humana desordenada.

Além da cobertura vegetal natural, a Cidade de São Paulo possui unidades de conservação, parques, praças, terrenos particulares, e a arborização urbana que enriquecem a paisagem e contribuem para a qualidade de vida de seus habitantes e conservação da biodiversidade.

O Município de São Paulo possui 38 parques municipais urbanos distribuídos pela Cidade, com uma área total de 1.598 hectares, que corresponde a 1,12\% da área total do município. Nesses parques é realizado um trabalho contínuo de inventário da fauna silvestre de animais vertebrados. 
Além dos parques municipais urbanos, o município gerencia o Parque Municipal Natural da Cratera, com 53 hectares, e duas áreas municipais de proteção ambiental, a APA Capivari Monos, com $251 \mathrm{Km}^{2}$, e a APA Bororé-Colônia, com $90 \mathrm{Km}^{2}$, todos localizados na região sul em áreas de remanescentes de Mata Atlântica.

A Cidade de São Paulo também possui unidades de conservação pertencentes e gerenciadas pelo Governo de Estado, sendo: 03 Áreas de Proteção Ambiental (APA), 09 parques, sendo 03 deles urbanos. O Parque Estadual da Serra do Mar é a maior Unidade de Conservação do Estado de São Paulo e ocupa uma área de $44 \mathrm{Km}^{2}$ ao sul da cidade.

Não obstante o número e as dimensões das áreas verdes protegidas, o fluxo gênico é prejudicado pela fragmentação. Pressionados, alguns animais são vítimas de atropelamentos, eletrocussões, incêndios, atos de vandalismo, captura, entre outras ocorrências. Tanto a fauna quanto a flora também sofrem ameaçadas pela introdução de espécies exóticas invasoras e pelo comércio ilegal.

A Cidade de São Paulo é uma dos maiores centros consumidores de fauna silvestre retirada ilegalmente da natureza (WWF, 1995); (RENCTAS, 1999).

\subsection{CRIAÇÃO DO SERVIÇO MUNICIPAL DE GESTÃo E MANEJO DA FAUNA SILVESTRE}

\subsubsection{Histórico ${ }^{20}$}

Em 03 de janeiro de 1989, foi apresentado o "Projeto Criação do Serviço Médico Veterinário, Biologia e de Manejo de Fauna no Departamento de Parques e Áreas Verdes", ligado à Secretaria de Serviços e Obras da Prefeitura de São Paulo, que culminou na criação da Divisão Técnica de Medicina Veterinária e Biologia da Fauna, pela Lei Municipal n 11.426, de 18 de outubro de 1993.

\footnotetext{
${ }^{20}$ Processo PMSP - SSO/DEPAVE nº 02.003.176-92*66.
} 
Durante os anos em que o serviço operava informalmente, como uma política de governo, foi publicada em 24 de abril de 1992 a Portaria n 008/DEPAVE-G/92, no Diário Oficial do Município que constava:

Considerando a grande diversidade de espécies animais que são encontradas nos Parques Municipais, e o interesse deste Departamento de Parques e Áreas Verdes na prestação de uma assistência médica veterinária a essas espécies, assim como no seu manejo adequado,

Resolve: designar (...), para implantarem, coordenarem e executarem junto ao DEPAVE-5, o projeto referente a "criação do serviço médico-veterinário, biologia e de manejo de fauna no DEPAVE" (anexo 3).

Na Portaria, a informação sobre "a grande diversidade de espécies animais encontradas nos Parques Municipais", baseava-se na lista de fauna que compunha o projeto de criação do serviço e que relacionava 126 diferentes espécies de animais vivendo nos parques da Cidade de São Paulo, sendo: 92 aves; 26 mamíferos e 08 répteis, a partir de observações de campo e pesquisa bibliográfica.

Até que fosse criado por lei, o serviço recebeu no nome de Unidade Médica Veterinária do DEPAVE.

Em 18 de outubro de 1993, pela Lei Municipal no 11.426, foi criada a Divisão Técnica de Medicina Veterinária e Biologia da Fauna (DEPAVE-3), tendo por atribuições, "promover a preservação e a conservação da fauna, com acompanhamento médico-veterinário curativo, profilático, biológico, sanitário, nutricional e reprodutivo" (SÃO PAULO (Município), 1993).

A Divisão foi criada com diversas atribuições, e entre elas, o manejo de animais silvestres vitimados e a realização do inventário faunístico da Cidade de São Paulo (ALMEIDA et al., 2003).

No processo que durou cinco anos para institucionalização, a criação do serviço foi apoiado por instituições não governamentais como a União Internacional de Proteção Animal (UIPA) e o Grupo Tucuxi, por intermédio do Conselho de Proteção e Defesa Animal (CPDA), órgão consultivo ligado ao Centro de Controle de Zoonoses da Prefeitura de São Paulo. 
Merece destaque, o primeiro apoio ao projeto manifestado pelo $\mathrm{PhD}$ Chris Wermer $^{21}$, em uma carta (anexo 4) endereçada ao então Prefeito Jânio Quadros, em 05 de dezembro de 1988, onde mencionava que tomara conhecimento da rica fauna paulistana e do projeto, e acrescentava:

$\mathrm{Eu}$ estimulo-o fortemente a promover o programa alocando fundos para o suporte de funcionários, de equipamento $\mathrm{e}$ suplementos. Infelizmente, poucas pessoas compreendem ou apreciam a importância da gestão da vida selvagem. Conhecendo seu interesse e preocupação para com os animais silvestres, eu tenho esperança que as medidas apropriadas possam ser adotadas para melhorar a capacidade desta cidade na proteção desse valioso recurso*.

Quando o serviço foi criado por lei, essa não contemplou todas as estruturas propostas no organograma original do projeto, como os setores de reabilitação, laboratório e de nutrição.

Em 24 de maio de 1995, a Portaria nº 044/SVMA.G/95 constituiu o Centro de Reabilitação de Animais Silvestres (CRAS), ligado ao DEPAVE-3, definindo a sua localização e relacionando as suas atribuições.

Somente em 9 de maio de 1996 é publicada a Lei Municipal $n^{\circ} 12.055$, que autoriza a implantação do Centro de Reabilitação de Animais Silvestres - CRAS e do Centro de Triagem de Animais Silvestres - CETAS, como Seções Técnicas do DEPAVE-3:

Art. $1^{\circ}$ - Fica o Executivo autorizado a implantar, no Parque Anhanguera, o Centro de Triagem de Animais Silvestres

\footnotetext{
${ }^{21}$ Assistant Director for Conservation of Research Center - National Zoological Park, Front Royal, Virginia, USA, and Smithsonian Intitution - Coordenador do Curso de Treinamento em Biologia e Manejo de Animais Silvestres [Zoo Animal Management], realizado no período de 16 de novembro a 10 de dezembro de 1988, na Fundação Parque Zoológico de São Paulo. " ["I strongly urge you to support the program by allocating funds for the support of staff, equipment and supplies. Unfortunately, few people understand or appreciate the importance of wildlife managment. Knowing your own interest and concern for wildlife however, I am hopeful that the proper measures can be taken to improve this city's ability to safeguard this valuable resource"].
} 
(CETAS) e o Centro de Reabilitação de Animais Silvestres (CRAS).

Parágrafo único. O CETAS e o CRAS ficam subordinados à Divisão Técnica de Medicina Veterinária e Biologia da Fauna (DEPAVE-3), do Departamento de Parques e Áreas Verdes DEPAVE, da Secretaria do Verde e do Meio Ambiente - SVMA (SÃO PAULO (Município), 1996).

Essa lei foi regulamentada pelo Decreto Municipal $n^{\circ} 37.653$ de 25 de setembro de 1998 (SÃO PAULO (Município), 1998).

Em 2002, a Divisão Técnica de Medicina Veterinária e Biologia da Fauna (DEPAVE-3), passa a ser denominada Divisão Técnica de Medicina Veterinária e Manejo da Fauna Silvestre (DEPAVE-3).

\subsubsection{Organograma}

A partir de 1996, o DEPAVE-3 passa a operar com outras estruturas em seu organograma (figura 5). 
Figura 5 - Organograma do DEPAVE-3.

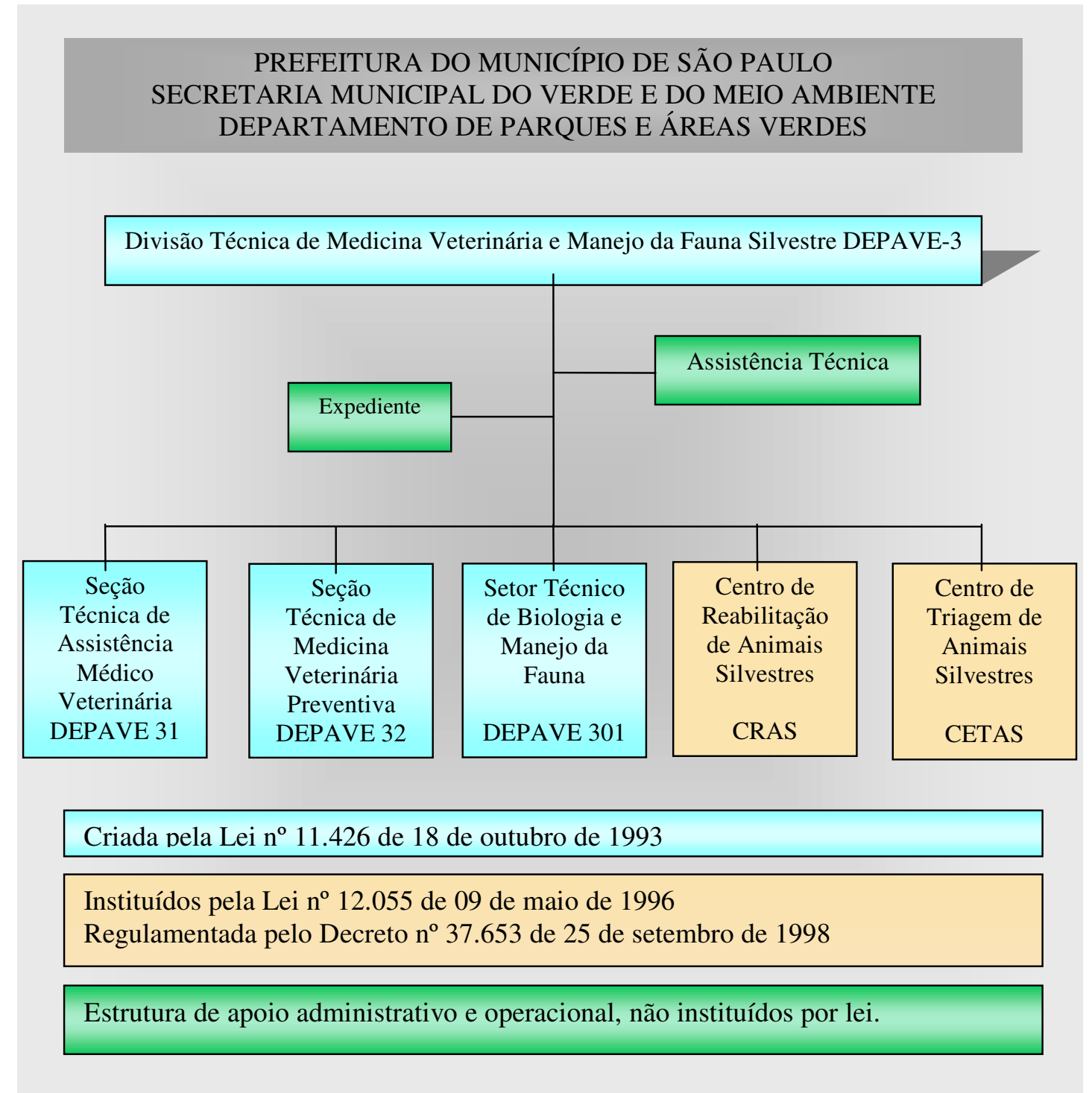

Fonte: Extraída de BRANCO (2002).

Elaborada por Cristina Brites 


\subsubsection{Atribuições}

As atribuições ${ }^{22,23,24}$ do DEPAVE-3 encontram-se descritas para cada uma de suas unidades:

A Seção Técnica de Assistência Médico Veterinária (DEPAVE-31) recebe todos os animais resgatados e atua como um serviço hospitalar, onde é prestada toda assistência veterinária clínica e cirúrgica, com o suporte laboratorial.

Cidadãos, policiais do Corpo de Bombeiros e agentes de controle de zoonoses normalmente levam animais vitimados por acidentes, órfãos, ou recolhidos do interior de domicílios. A Polícia Ambiental e o IBAMA levam animais apreendidos do comércio ilegal, em ações de fiscalização.

Os problemas de saúde mais freqüentes nos animais decorrem de atropelamentos, queimadas, colisões em vidraças, eletrocussões, caçadas, agressões, maus tratos e tráfico.

Após a alta clínica, os animais que necessitam de reabilitação são encaminhados ao Centro de Reabilitação de Animais Silvestres (CRAS).

No CRAS, os animais são assistidos para readquirirem as condições anatômicas e fisiológicas que possibilitem sua recolocação na natureza. Os principais trabalhos de reabilitação estão voltados à recuperação de fraturas, penas danificadas, capacidade de vôo e de obtenção de alimento, além da criação de filhotes órfãos.

Todos os animais recebidos no DEPAVE-3 são destinados através do Centro de Triagem de Animais Silvestres (CETAS).

\footnotetext{
${ }^{22}$ BRANCO, A. M., CAVAlHEIRO, T. L., Manejo de Fauna na Cidade de São Paulo. In: SMA SECRETARIA DE ESTADO DO MEIO AMBIENTE. Seminário sistemas de recepção, manejo e destinação de animais silvestres. Cananéia, 1999. Relatórios Ambientais.

${ }^{23}$ PMSP. Secretaria do Verde e do Meio Ambiente. PROFAUNA: Programa de Manejo da Fauna Silvestre Interativo com a Cidade. São Paulo, Ag. 2001. CD-ROOM.

${ }^{24}$ BRANCO, A. M. Centro de Manejo de Animais Silvestres. In: GIOVANINI, D. (Org.). Animais silvestres: vida à venda. Brasília, DF: Dupligráfica, 2002. p. 235-253.
} 
No CETAS são mantidos os animais que aguardam destinação. O CETAS é a seção que faz a triagem, avaliando todas as possibilidades do animal e respondendo pelas solturas ou envio para zoológicos e criadouros autorizados pelo IBAMA.

\section{A Seção Técnica de Medicina Veterinária Preventiva (DEPAVE-32)}

responde pela fauna dos 38 Parques Municipais. Em parques com lagos são mantidos animais silvestres exóticos e domésticos, como: cisnes, gansos e marrecos, que convivem com a fauna silvestre de vida livre, como: garças, irerês e biguás. Esses animais são acompanhados quanto às necessidades biológicas e aspectos comportamental, nutricional e reprodutivo.

Essa seção também responde por ações voltadas ao controle de animais domésticos e sinantrópicos nos parques e vigilância ambiental, em conjunto com os agentes de saúde da Prefeitura, além da criação da "Campanha EducaCão", que tem por objetivo orientar os usuários de parques sobre a necessidade da condução de cães com coleira e guia e recolhimento das fezes, atendendo a Lei Municipal $n^{\circ} 10.309$ de 22 de maio de 1987. A campanha é uma das ações do "Programa EducaCão nos Parques Municipais", instituído pela Portaria 74/SVMA.G/99. (SÃO PAULO (Município), 1999).

Subsidiando todas as seções técnica com informações sobre a fauna da cidade, o Setor Técnico de Biologia e Manejo da Fauna (DEPAVE-301) responde pelo inventário faunístico nos parques municipais e áreas verdes significativas, que permite a localização georreferenciada da ocorrência de espécies animais e subsidia estudos sobre a biodiversidade do Município de São Paulo. Esse setor também tem por atribuição realizar o anilhamento da avifauna e monitoramento de solturas.

Enquanto o DEPAVE-31, CRAS e CETAS têm suas atividades voltadas principalmente aos animais internados, o DEPAVE-32 e o DEPAVE-301 têm suas atividades voltadas para a fauna da cidade, a partir dos trabalhos realizados nos parques municipais. Dessa forma o DEPAVE-3 está estruturado para realizar o manejo de animais silvestres dentro de suas dependências, e o manejo da fauna silvestre quando atua com as populações de animais, espécies de vida livre e ambiente, como é próprio da medicina veterinária preventiva e da biologia. 
Dando suporte para a área técnica, existe uma estrutura administrativa formada por funcionários de nível médio e básico que desempenham funções diversas para a operacionalização dos serviços. Outros funcionários, de nível universitário, também desempenham funções de assistência técnica, como por exemplo, na área de informação.

Os procedimentos realizados com os animais são documentados em fichas que são empregadas pelas diferentes seções e setores do DEPAVE-3, que compõem o prontuário dos animais atendidos. Para o gerenciamento de dados sobre a fauna recebida e destinada, o DEPAVE-3 possui um banco de dados denominado SISFAUNA, que permite a consulta imediata às informações dos animais atendidos, a partir do documento de retenção.

A equipe técnica também responde pela elaboração de material para publicação, realiza cursos relacionados à fauna, presta atendimento telefônico para pessoas que procuram o serviço para sanar dúvidas, além de proporcionar visitas técnicas monitoradas pela sede do DEPAVE-3.

\subsubsection{Recursos $^{25}$}

Não foi possível determinar o valor dos recursos financeiros empregados diretamente na gestão da fauna pelo DEPAVE-3, uma vez que apesar de possuir uma dotação orçamentária própria, esta é destinada para a compra de equipamentos e materiais, além de pagamentos de serviços voltados aos gastos relacionados diretamente com os animais, não refletindo os custos do serviço. Porém, alguns dados sobre o orçamento da SVMA, ao longo dos últimos anos, refletem a atenção que as questões ambientais têm alcançado, e que também repercutem nos recursos distribuídos entre as diferentes unidades da Secretaria.

De 2003 a 2007, o orçamento da SVMA ${ }^{26}$ em relação ao orçamento da PMSP sofreu as seguintes variações em termos percentuais: 0,$52 ; 0,54 ; 0,61 ; 0,57 ; 0,97$; partindo da ordem de R\$ 55.178.440,28 em 2003 para R\$208.787.290,00 em 2007.

\footnotetext{
${ }^{25}$ PMSP. Secretaria Municipal do Verde e do Meio Ambiente. ICLEI (Internacional Council for Local Environmental Iniciatives. LAB. Local Action for Biodiversitu of São Paulo City (2008). No prelo.
} 
Com relação aos recursos humanos, o DEPAVE-3 conta com 59 funcionários, sendo: 28 técnicos de nível superior (17 médicos veterinários e 11 biólogos), 11 tratadores de animais e 20 operacionais (vigias e auxiliares de limpeza). Além do corpo efetivo de funcionários, a Divisão também conta com 21 universitários (10 de Biologia e 11 de Medicina Veterinária) contratados como estagiários por 1 ou $2 \operatorname{anos}^{27}$.

Dentre os 11 Biólogos, 03 possuem Doutorado, 04 Mestrado, e 02 Especialização; enquanto que entre os 17 Médicos Veterinários, 03 possuem Mestrado e 11 Especialização, revelando uma alta qualificação técnica dos funcionários.

Todos os funcionários que trabalham no DEPAVE-3 recebem além do pagamento mensal referente à carreira, um adicional por insalubridade e uma remuneração pela prestação de serviços de saúde, em reconhecimento dos riscos que estão submetidos pelas práticas realizadas com os animais e trabalhos voltados à área de saúde.

Todos os funcionários que atuam diretamente com os animais e estagiários são imunizados minimamente contra a raiva e tétano.

Como estrutura física, o DEPAVE-3 conta com duas sedes, uma no Parque Ibirapuera e a outra no Parque Anhanguera, onde estão instalados o CRAS e o CETAS.

A capacidade de suporte para internação de animais é bastante variada, uma vez que depende das espécies alojadas. Segundo o DEPAVE- $3^{28}$, no dia 05 de fevereiro de 2007, havia 585 animais internados em ambas as sedes, sendo: 429 aves; 86 mamíferos e 70 répteis, e todos os recintos encontravam-se ocupados.

Um problema que é enfrentado pela equipe diz respeito a sua estrutura física, tanto no Parque Ibirapuera como no Anhanguera, que não condizem com as exigências do serviço. A construção de uma nova sede denominada de "Centro de Manejo e Preservação da Fauna Silvestre - SP Fauna Silvestre do Parque Anhanguera"29 está em

\footnotetext{
${ }^{26}$ Informações fornecidas por SGA (Supervisão Geral Administrativa) da SVMA, 2007.

${ }^{27}$ Informações fornecidas pela Coordenadoria de Estágios da Divisão de Desenvolvimento Pessoal da SVMA.

${ }^{28}$ Relatório de Atividades do DEPAVE-3 referente ao ano de 2007, encaminhado para o IBAMA.

${ }^{29}$ Diário Oficial da Cidade de São Paulo, 19 de jun. 2008, v. 53, n.107, p. 73.
} 
fase de implantação para melhor atender a demanda da Divisão, principalmente as relacionadas aos procedimentos hospitalares ${ }^{30}$.

Parte dos recursos para a implantação do projeto é proveniente de compensação ambiental pela construção do trecho oeste do Rodoanel Metropolitano de São Paulo, porém, o valor mais expressivo, é proveniente da venda de créditos de carbono pela queima de gás metano, em um aterro sanitário existente próximo ao Parque Anhanguera.

Os projetos arquitetônico e executivo contemplam estrutura hospitalar completa, quarentenário, e recintos de internação e reabilitação mais apropriados à demanda dos serviços, bem como propiciam que visitantes possam conhecer os trabalhos, ampliando as visitas monitoradas que atualmente ocorrem na sede do Parque Ibirapuera, porém com limitações devido a inadequação das instalações para tal atividade.

\section{DESCRIÇÃO E ANÁLISE DA GESTÃO E DO MANEJO DA FAUNA SILVESTRE NATIVA NA PREFEITURA DE SÃO PAULO}

\subsection{INVENTÁRIO FAUNÍSTICO}

Partindo do princípio que os animais vitimados, procedentes da natureza, possuem grandes chances de serem recolocados após passarem por uma avaliação técnica criteriosa, fazia-se necessário o reconhecimento da fauna existente no âmbito do Município de São Paulo.

Dessa forma, o DEPAVE-3 iniciou oficialmente em 1993 o "Projeto Inventariamento Faunístico em Áreas Verdes do Município de São Paulo".

No período de 1993 a 2006, a Prefeitura de São Paulo fez várias publicações do resultado do projeto $^{31}$. Na última publicação foram totalizadas 48 áreas verdes pesquisadas (figura 6), representativas da cidade. Nelas foram registradas a ocorrência

\footnotetext{
${ }^{30}$ SVMA. Processo Administrativo no ${ }^{2008.0 .002 .196-3 ~-~ E x e c u c ̧ a ̃ o ~ d e ~ s e r v i c ̧ o s ~ e ~ o b r a s ~ d e ~ i m p l a n t a c ̧ a ̃ o ~}$ do Hospital Veterinário no Parque Anhanguera.

${ }^{31}$ Capítulo sobre o Projeto em SILVA, et al. (1993) e publicação de quatro listas da fauna inventariada na cidade: SÃO PAULO (1998 ${ }^{a}$ ); SÃO PAULO, (1999 ); SÃO PAULO, (2000); SÃO PAULO, (2006).
} 
de 429 espécies de animais vertebrados, sendo: 285 pertencentes ao grupo das aves, 58 dos mamíferos, 37 dos répteis, 40 dos anfíbios e 09 dos peixes (anexo 5), além de 06 espécies de animais invertebrados (SÃO PAULO, 2006). 
Figura 6 - Mapa da Cidade de São Paulo com a localização de áreas protegidas e locais onde foram realizados os estudos de inventário da fauna, no período de 1993 a 2005. São Paulo, 2007.

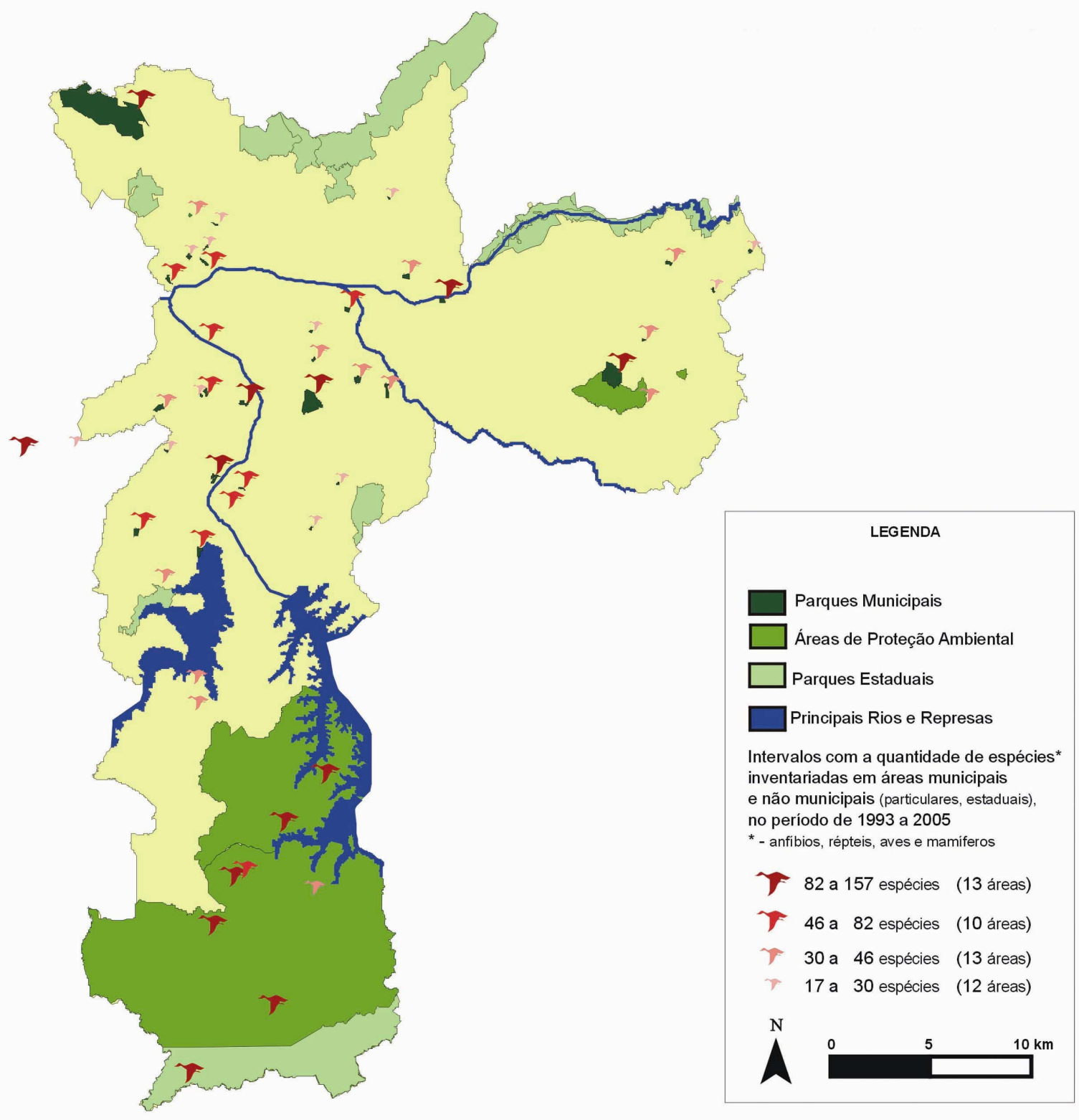

Fonte: DEPAVE-3.

Elaborada por Marcos K. Vasconcelos e Pedro H.N. Cunha. 
No inventário foram incluídas as espécies observadas durante os trabalhos de campo e as atendidas pelo DEPAVE-3, cuja procedência do Município de São Paulo tenha sido comprovada. Esses dados não refletem exatamente a fauna existente no Município, porém confirmam as espécies que seguramente ocorrem na região.

O inventário faunístico revelou a presença de algumas espécies que foram introduzidas de outras regiões do País, porém o seu acompanhamento é realizado apenas com os registros das ocorrências.

Com relação às aves, das 285 espécies, foram registradas 19 diferentes ordens, 53 famílias e 233 gêneros. Quanto aos mamíferos, das 58 espécies foram registradas 10 diferentes ordens, 22 famílias e 49 gêneros.

Dentre as 435 espécies de animais inventariadas, 73 espécies são endêmicas da Mata Atlântica e 14 espécies estão provavelmente ameaçadas de extinção no Estado de São Paulo, segundo o Decreto Estadual no 42.838/98 (SÃO PAULO (Município), 2006).

Merece destaque no inventário da fauna, a ocorrência da onça-parda (Puma concolor), considerada uma espécie vulnerável à extinção no Estado de São Paulo (SÃO PAULO, 1998), ameaçada de extinção na Lista da Fauna Brasileira Ameaçada de Extinção (2003); no apêndice II da CITES (2006); e como quase ameaçada na Lista Vermelha Mundial da IUCN (IUCN, 2006), além de ser o segundo maior predador da fauna silvestre brasileira.

O inventario da fauna é um exemplo do resultado da gestão da fauna pelo Poder Público, pois além de refletir um diagnóstico do meio, também representa uma ferramenta de planejamento da Cidade, para o caso em que o meio venha a ser, de fato, considerado.

Esse inventário da fauna da Cidade, único do País realizado pelo Poder Público, cumpre papéis fundamentais (CBD, 2007):

- Respalda as solturas de animais realizadas pelo DEPAVE-3;

- Subsidia a elaboração de estudos e relatórios de impacto ambiental na Cidade;

- Direciona projetos de manejo de áreas verdes do Município;

- Gera indicadores ambientais;

- Orienta as políticas públicas local; 
- É fonte de informações para publicações como o Atlas Ambiental do Município de São Paulo, GEO Cidade de São Paulo, Fauna Silvestre da Cidade;

- Contribui na catalogação da biodiversidade do Estado de São Paulo.

\subsection{MANEJO DA FAUNA SILVESTRE NATIVA}

O manejo de animais silvestres realizado pelo DEPAVE 3 compreende todos os procedimentos realizados com os animais durante o processo de sua internação, como: captura, contenção, transporte, atendimento médico veterinário, atendimento biológico, ambientação no recinto, alimentação, reabilitação, soltura. Isso implica que, desde o momento da entrada do animal no serviço, até que o mesmo seja solto ou entregue para uma outra instituição, ele estará submetido ao constante manejo por parte da equipe de trabalho (BRANCO, 2002).

Nesse sentido, o DEPAVE-3 conta com um protocolo, elaborado pela própria equipe, contendo as normas de procedimentos que descreve de maneira detalhada as rotinas das diferentes unidades da Divisão, tanto na esfera técnica, como na administrativa e operacional. ${ }^{32}$

\subsubsection{Atendimento Médico Veterinário e Biológico dos Animais}

Dentre as atribuições do DEPAVE-3 destaca-se o atendimento médico veterinário curativo e preventivo com acompanhamento biológico de animais silvestres que deram entrada no serviço, após serem resgatados de acidentes ou apreendidos pela fiscalização, principalmente na Região Metropolitana de São Paulo.

A entrada dos animais ocorre pela Seção Técnica de Assistência Médico Veterinária, onde os mesmos recebem o atendimento médico veterinário clínico e cirúrgico. Dependendo do histórico, são colhidos materiais biológicos como sangue, urina e fezes para uma avaliação do estado de saúde, além da pesquisa de doenças

\footnotetext{
${ }^{32}$ DEPAVE-3. Normas de Procedimentos da Divisão Técnica de Medicina Veterinária e Biologia da Fauna, São Paulo, 2001.
} 
infecciosas e parasitárias, em especial as zoonoses, a exemplo dos mamíferos onde é pesquisada a raiva e a toxoplasmose (SILVA et al., 2000), a leptospirose (CORRADO, 2001) entre outras, dependendo da espécie do animal.

Os animais que vêm a óbito, também dependendo do histórico e espécie, são submetidos ou encaminhados para exame de necropsia para detecção da causa mortis. Em alguns casos é aproveitada a pele ou o esqueleto para compor o acervo de peças biológicas da própria Divisão ou doação para museus.

Todos os animais permanecem internados até o momento da destinação, sendo que, durante esse período recebem acompanhamento biológico onde são realizadas a identificação, biometria e marcação, além da orientação quanto à dieta e adequação do recinto de internação para o espécime, sempre na dependência da espécie.

A partir dos dados do SISFAUNA, foi constatado que as espécies de aves mais atendidas no DEPAVE-3, no período de 1991 a 2003 foram: rolinha (Columbina talpacoti), corujinha-do-mato (Otus choliba), sabiá-laranjeira (Turdus rufiventris), bemte-vi (Pitangus sulphuratus), coruja-orelhuda (Rhinoptynx clamator) e periquito-rico (Brotogeris tirica). Para Columbina talpacoti, o principal motivo de entrada foi o recolhimento de filhotes em fase de aprendizado de vôo. Para a Otus choliba e Rhinoptynx clamator, $24,6 \%$ das entradas foram de filhotes e outros $24 \%$ foram devidos a traumas diversos. O Brotogeris tirica freqüentemente é recebido com lesões provocadas por linhas de pipa (ALMEIDA et al., 2003).

Quanto aos animais apreendidos pelos agentes de fiscalização, encontram-se principalmente as aves canoras, como o canário-da-terra (Sicalis flaveola), galo-dacampina (Paroaria dominicana), cardeal (Paroaria coronata), e várias espécies de Sporophila como os coleirinhos e bigodinhos. Também, é comum o recebimento de psittaciformes como araras, papagaios e periquitos; primatas como sagüis e macacosprego; e répteis como jabutis e cágados.

Os bugios (Alouatta guariba clamitans), que habitam fragmentos dos remanescentes da Mata Atlântica da Cidade, são bons exemplos de animais vitimados pela pressão humana. Dados do DEPAVE-3 revelam que, de um total de 138 animais recebidos para tratamento no período de janeiro de 1992 a janeiro de 2006, 61,6\% 
vieram da Zona Norte, e 27,5\% da Zona Sul. A entrada desses animais no serviço revelam impactos causados pela expansão urbana, como: eletrocussões provocadas por fios de alta tensão; ataques por cães; atropelamentos; além do recebimento de filhotes órfãos (SUMMA et al., 2006).

Desde a implantação do serviço até meados de julho de 2008, foram atendidos mais de 34.400 animais.

Durante o período de 1992 a 2007, o DEPAVE-3 prestou atendimento a 33.118 animais (tabela 1), pertencentes à fauna silvestre nativa, exótica e doméstica, que foram encaminhados para o serviço por terem sido resgatados, apreendidos ou recolhidos.

Tabela 1 - Número de animais que deram entrada no DEPAVE-3, segundo o ano da entrada e o grupo, no período de janeiro de 1992 a dezembro de 2007. São Paulo, 2008.

\begin{tabular}{ccccc}
\hline Grupo & Aves & Mamíferos & Répteis & $\begin{array}{c}\text { Total } \\
\mathbf{N}\end{array}$ \\
\hline 1992 & 244 & 72 & 18 & 334 \\
1993 & 504 & 197 & 54 & 755 \\
1994 & 741 & 301 & 64 & 1.106 \\
1995 & 823 & 556 & 164 & 1.543 \\
1996 & 955 & 657 & 297 & 1.909 \\
1997 & 1.669 & 759 & 124 & 2.552 \\
1998 & 1.118 & 503 & 115 & 1.736 \\
1999 & 2.276 & 501 & 162 & 2.939 \\
2000 & 2.354 & 517 & 189 & 3.060 \\
2001 & 3.079 & 413 & 210 & 3.702 \\
2002 & 1.844 & 424 & 141 & 2.409 \\
2003 & 1.648 & 412 & 102 & 2.162 \\
2004 & 1.894 & 298 & 117 & 2.309 \\
2005 & 1.716 & 305 & 61 & 2.082 \\
2006 & 1.759 & 296 & 137 & 2.192 \\
2007 & 1.877 & 351 & 100 & 2.328 \\
\hline Total & 24.501 & & & \\
\hline Fon & & 6.562 & 2.055 & 33.118 \\
\hline
\end{tabular}

Fonte: DEPAVE -3, 2008. 
Apesar de ser um serviço voltado ao atendimento da fauna silvestre nativa, também acaba atendendo outras demandas envolvendo os silvestres exóticos e até animais domésticos, que direta ou indiretamente convivem com a fauna silvestre nativa.

Durante o período de 1992 a 2007, o DEPAVE 3 prestou atendimento a 27.779 animais pertencentes à fauna silvestre nativa (tabela 2), ou seja, 83,88\% do total de animais atendidos, e que foram encaminhados para o serviço por terem sido resgatados ou apreendidos.

Tabela 2 - Número de animais silvestres nativos que deram entrada no DEPAVE-3, segundo o ano da entrada e o grupo, no período de janeiro de 1992 a dezembro de 2007. São Paulo, 2008.

\begin{tabular}{ccccc}
\hline Grupo & Aves & Mamíferos & Répteis & $\begin{array}{c}\text { Total } \\
\mathbf{N}\end{array}$ \\
\hline 1992 & & & & 167 \\
1993 & 98 & 51 & 18 & 372 \\
1994 & 215 & 103 & 54 & 661 \\
1995 & 368 & 230 & 63 & 1.073 \\
1996 & 574 & 335 & 164 & 1.407 \\
1997 & 665 & 453 & 289 & 1.963 \\
1998 & 1.448 & 401 & 114 & 1.360 \\
1999 & 906 & 381 & 73 & 2.394 \\
2000 & 1.950 & 344 & 100 & 2.603 \\
2001 & 2.115 & 398 & 90 & 3.363 \\
2002 & 2.843 & 348 & 172 & 2.214 \\
2003 & 1.720 & 398 & 96 & 1.951 \\
2004 & 1.481 & 393 & 77 & 2.075 \\
2005 & 1.704 & 273 & 98 & 1.947 \\
2006 & 1.602 & 296 & 49 & 2.056 \\
2007 & 1.642 & 288 & 126 & 2.173 \\
\hline
\end{tabular}

Fonte: DEPAVE -3, 2008.

O grupo das aves representa o maior número de atendimento, seguido pelos mamíferos e répteis. 
As entradas se devem a diversos motivos (figura 7), principalmente quando os animais são provenientes da região, porém, um grande número corresponde a animais que foram apreendidos pelos órgãos de fiscalização.

Figura 7 - Número de animais silvestres nativos que deram entrada no DEPAVE-3, segundo o ano e o motivo da entrada, no período de janeiro de 1992 a dezembro de 2007. São Paulo, 2008.

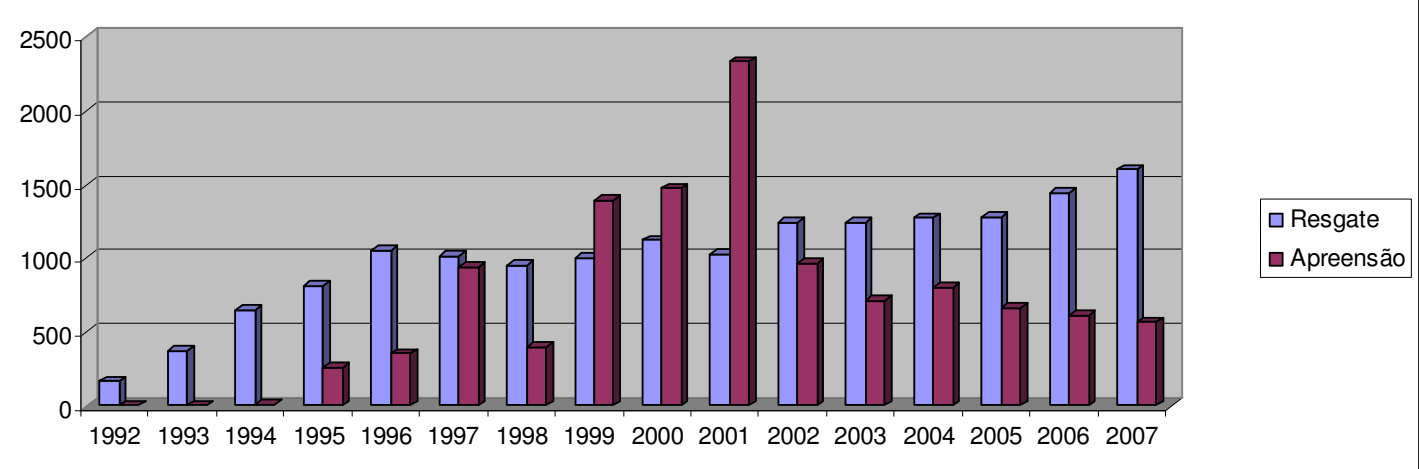

Fonte: DEPAVE -3, 2008.

Notas:

Resgate - Animais de vida livre ou do acervo dos parques municipais.

Apreensão: Polícias (Militar e Civil) e IBAMA.

Dos 27.779 animais silvestres nativos atendidos durante o período de 1992 a 2007, $16.269(58,57 \%)$ haviam sido resgatados, enquanto que $11.510(41,43 \%)$ haviam sido apreendidos pelos órgãos de fiscalização.

Nota-se que, apesar do número total de animais resgatados ser maior do que o dos apreendidos, apenas durante o período de 1999 a 2001 ocorreu uma inversão, não devido a diminuição dos resgatados, mas pelo aumento significativo do número dos apreendidos, época em que a discussão sobre o tráfico de animais silvestres estava em muita evidência no cenário nacional, principalmente devido a promulgação da Lei de Crimes Ambientais n 9.605/98, regulamentada em 1999.

Com relação aos resgatados, o número de animais apresenta uma tendência de crescimento, que pode ser decorrente da divulgação do serviço prestado pela Prefeitura. 


\subsubsection{Pesquisas e Exames Laboratoriais}

Durante os procedimentos de manejo dos animais e mediante a necessidade, materiais biológicos como sangue, fezes, urina, raspados de pele são colhidos para exame na própria unidade, ou encaminhados para pesquisadores e laboratórios especializados. A colheita do material atende um protocolo, previamente estipulado.

Os exames laboratoriais (tabela 3), realizados nos materiais colhidos dos animais internados ou que tiveram óbito, visam diagnosticar doenças, inclusive inaparentes. Esse procedimento conta com a participação de pesquisadores, institutos de pesquisas e universidades, além de laboratórios particulares.

Tabela 3 - Número de exames realizados nos animais internados, segundo o ano e o tipo de exame, no período de 1994 a $1999^{33}$. São Paulo, 2008.

\begin{tabular}{lccccc}
\hline Ename & $\begin{array}{c}\text { Sorológico } \\
\text { Hemograma }\end{array}$ & Parasitológico & $\begin{array}{c}\text { Histopatologia e } \\
\text { Necropsia }\end{array}$ & Cariótipo & Total \\
\hline 1994 & 163 & 350 & 194 & 0 & 707 \\
1995 & 248 & 393 & 166 & 0 & 807 \\
1996 & 257 & 861 & 408 & 7 & 1.533 \\
1997 & 757 & 736 & 396 & 0 & 1.889 \\
1998 & 578 & 696 & 378 & 19 & 1.671 \\
1999 & 571 & 1.107 & 149 & 19 & 1.846 \\
\hline \multicolumn{7}{r}{ Total } & 2.574 & 4.143 & 1.691 & 45 & 8.453 \\
\hline Fonte
\end{tabular}

Na relação dos exames sorológicos está incluída a pesquisa de doenças como a raiva, leptospirose, toxoplasmose, arbovirose, hepatite, malária.

Nos parasitológicos estão incluídos os exames para pesquisa de endo e ectoparasitas.

\footnotetext{
${ }^{33}$ Os dados referentes aos exames encontram-se disponíveis apenas nos Relatório Anuais do DEPAVE-3, no período de 1994 a 1999.
} 
Além dos exames laboratoriais, outros exames como raios $\mathrm{X}$ e ultrasonografia também são realizados, mediante a necessidade do caso clínico.

A realização de exames laboratoriais está voltada tanto à saúde dos animais como a do homem, uma vez que a maioria dos animais que chega ao serviço é manipulada por pessoas que desconhecem os riscos de transmissão de doenças. Também, devido ao fato desses animais viverem em áreas urbanas, próximos de animais domésticos e da população humana.

Como exemplo desse risco, destaca-se a comprovação da presença da raiva em morcegos insetívoros, doentes, resgatados de parques urbanos localizados na Cidade de São Paulo e encaminhados pelo DEPAVE-3 para diagnóstico no Centro de Controle de Zoonoses (CCZ), da Prefeitura de São Paulo ${ }^{34}$.

\subsubsection{Reabilitação e Destino dos Animais Atendidos}

Simultaneamente à assistência médica, os animais recebem acompanhamento biológico voltado à sua recuperação e reabilitação, para que possam ser recolocados na área de procedência, desde que sejam atendidos os critérios técnicos preconizados pela equipe de trabalho.

Os reflexos desse trabalho podem ser avaliados pelos números apontados em um estudo realizado pelos técnicos do DEPAVE-3. Entre 1992 e 2006, foram recebidos 24.692 animais, de 333 espécies, dos quais 12.579 foram soltos em áreas de procedência ou ocorrência da espécie. Assim, 51\% dos animais atendidos foram recolocados em seu ambiente natural. Os animais que não preencheram os quesitos de soltura foram destinados para zoológicos e outras instituições legalizadas ${ }^{35}$.

\footnotetext{
${ }^{34}$ Animais encontrados no Parque Municipal Tenente Siqueira Campos e Parque Estadual Alberto Loefgreen, e que foram encaminhados para exame de diagnóstico da raiva, no Centro de Controle de Zoonoses da Prefeitura da Cidade de São Paulo, nos anos de 1997 e 2001.

${ }^{35}$ PMSP. Secretaria Municipal do Verde e do Meio Ambiente. Local Action for Biodiversity of São Paulo City (2008). No prelo.
} 
Dentre os critérios de soltura adotados pelo DEPAVE-3, BRANCO (2002) destaca que, para que um animal seja recolocado no seu hábitat natural é necessária à observância da legislação e o cumprimento dos seguintes critérios:

- O animal deve ser solto na área de procedência do espécime, e dependendo da espécie, na área de sua ocorrência;

- Deve estar confirmada a ocorrência da espécie na área de soltura;

- Deverão ser realizados exames laboratoriais específicos para a espécie, com a finalidade de se detectar e investigar doenças inaparentes;

- O animal deve estar com a saúde, anatomia e fisiologia recuperadas;

- O animal deve estar identificado por método de marcação preconizado para a espécie;

- As solturas devem ser monitoradas, sempre que houver esta possibilidade.

A adoção desses critérios é justificável, pois, solturas realizadas de maneira indevida podem comprometer as espécies que já vivem na localidade e provocar desequilíbrio ambiental, devido aos riscos de:

- Introdução de uma espécie animal que não ocorre na área de soltura;

- Introdução de uma nova doença no meio silvestre.

Além desses riscos, um outro problema que normalmente ocorre é a morte do animal que foi solto sem condições físicas, ou sem aprendizado de sobrevivência na natureza.

Também é verificado se a área onde o animal se encontrava quando foi resgatado apresenta sinais recentes de degradação que impeça que a soltura seja realizada.

Os animais com procedência conhecida são recolocados no local de onde foram resgatados, ou próximo dele, mesmo que seja na Região Metropolitana de São Paulo, e nesse caso, mediante a expedição de guia de transporte pelo IBAMA. Já aqueles provenientes de apreensões sem procedência, dependendo da espécie, são soltos em áreas de ocorrência natural da espécie, confrontando dados de listas de inventário da fauna e consultas bibliográficas.

Porém, mesmo que os animais sejam procedentes da região, se não preenchem os critérios para soltura, são destinados ao cativeiro e encaminhados, com autorização do 
IBAMA, para zoológicos ou criadouros. O mesmo destino é dado para os animais pertencentes a espécies que não ocorrem na região de abrangência do serviço.

Quando observados os critérios de soltura adotados pelo DEPAVE-3, pode ser concluído que a maioria dos animais reintegrados são aqueles vitimados por acidentes. Esses animais, quando recuperados, têm grande chance de reintegração, pois sua procedência é conhecida.

Uma situação mais complexa envolve animais apreendidos pelos órgãos de fiscalização, vítimas do tráfico. Nas apreensões, normalmente não é possível registrar o histórico de procedência ou origem dos animais, e, dependendo da espécie, a falta de informações impossibilita sua recolocação na natureza. Esses acabam sendo destinados ao cativeiro, mesmo destino dado para os animais silvestres com características de domesticação.

Porém, CARVALHO (2007, p. 279) relata o caso de um gavião-carijó (Rupornis magnirostris) recebido no DEPAVE-3, em julho de 2002, trazido no ombro, e que apresentava bom estado nutricional, com as penas desgastadas pelo cativeiro. Após o tratamento e reabilitação para vôo e caça, a ave foi solta em novembro de 2002. Em junho de 2004, ela foi recuperada demonstrando o sucesso na sua adaptação à vida livre, por 1 ano e 7 meses.

Após a realização de todos os procedimentos indicados para recuperar cada animal recebido, o mesmo é transferido para o CETAS, responsável por sua destinação. Os 27.779 animais silvestres nativos atendidos durante o período de 1992 a 2007 tiveram diversas destinações (tabela 4). 
Tabela 4 - Número de animais silvestres nativos que deram saída do DEPAVE-3, segundo o ano e motivo da saída, no período de janeiro de 1992 a dezembro de 2007.

\begin{tabular}{|c|c|c|c|c|c|c|c|}
\hline$\underbrace{\text { Destino }}_{\text {Ano }}$ & Soltura $^{\mathbf{a}}$ & $\begin{array}{l}\text { Repatria- } \\
\text { mento b }\end{array}$ & Cativeiro & Morte $^{\mathbf{c}}$ & $\operatorname{Perda}^{d}$ & $\begin{array}{l}\text { CCZ/ } \\
\text { Pesquisa }\end{array}$ & Internado $^{\mathrm{e}}$ \\
\hline 1992 & 70 & 0 & 21 & 67 & 9 & 0 & 0 \\
\hline 1993 & 190 & 0 & 19 & 159 & 3 & 1 & 0 \\
\hline 1994 & 306 & 0 & 65 & 279 & 9 & 2 & 0 \\
\hline 1995 & 489 & 0 & 269 & 296 & 18 & 1 & 0 \\
\hline 1996 & 663 & 0 & 293 & 447 & 4 & 0 & 0 \\
\hline 1997 & 878 & 0 & 298 & 716 & 64 & 7 & 0 \\
\hline 1998 & 673 & 0 & 185 & 456 & 46 & 0 & 0 \\
\hline 1999 & 1.412 & 0 & 193 & 744 & 44 & 0 & 1 \\
\hline 2000 & 1.678 & 0 & 191 & 655 & 78 & 0 & 1 \\
\hline 2001 & 1.743 & 0 & 406 & 1.076 & 134 & 2 & 2 \\
\hline 2002 & 1.120 & 1 & 285 & 701 & 104 & 1 & 2 \\
\hline 2003 & 1.044 & 7 & 128 & 680 & 84 & 0 & 8 \\
\hline 2004 & 994 & 29 & 213 & 750 & 76 & 2 & 11 \\
\hline 2005 & 1.004 & 53 & 77 & 664 & 66 & 6 & 77 \\
\hline 2006 & 904 & 100 & 52 & 838 & 72 & 11 & 79 \\
\hline 2007 & 956 & 27 & 55 & 870 & 71 & 10 & 184 \\
\hline Total & 14.124 & 217 & 2.750 & 9.398 & 882 & 43 & 365 \\
\hline
\end{tabular}

Fonte: DEPAVE -3, 2008.

Notas:

a - em áreas verdes municipais ou em áreas de procedência ou ocorrência da espécie.

b - para outro Estado, por intermédio do IBAMA.

c - óbito, eutanásia, predação, recebido morto.

d - fuga, furto, desaparecimento.

e - mantido no DEPAVE-3 (Clínica, CRAS ou CETAS) até o dia 18 de maio de 2008.

As solturas aparecem em maior número, seguida dos óbitos e cativeiro (figura 8), além de outras destinações. 
Figura 8 - Percentual do número de animais silvestres nativos que deram saída do DEPAVE-3, segundo o motivo da saída, no período de janeiro de 1992 a dezembro de 2007. São Paulo, 2008.

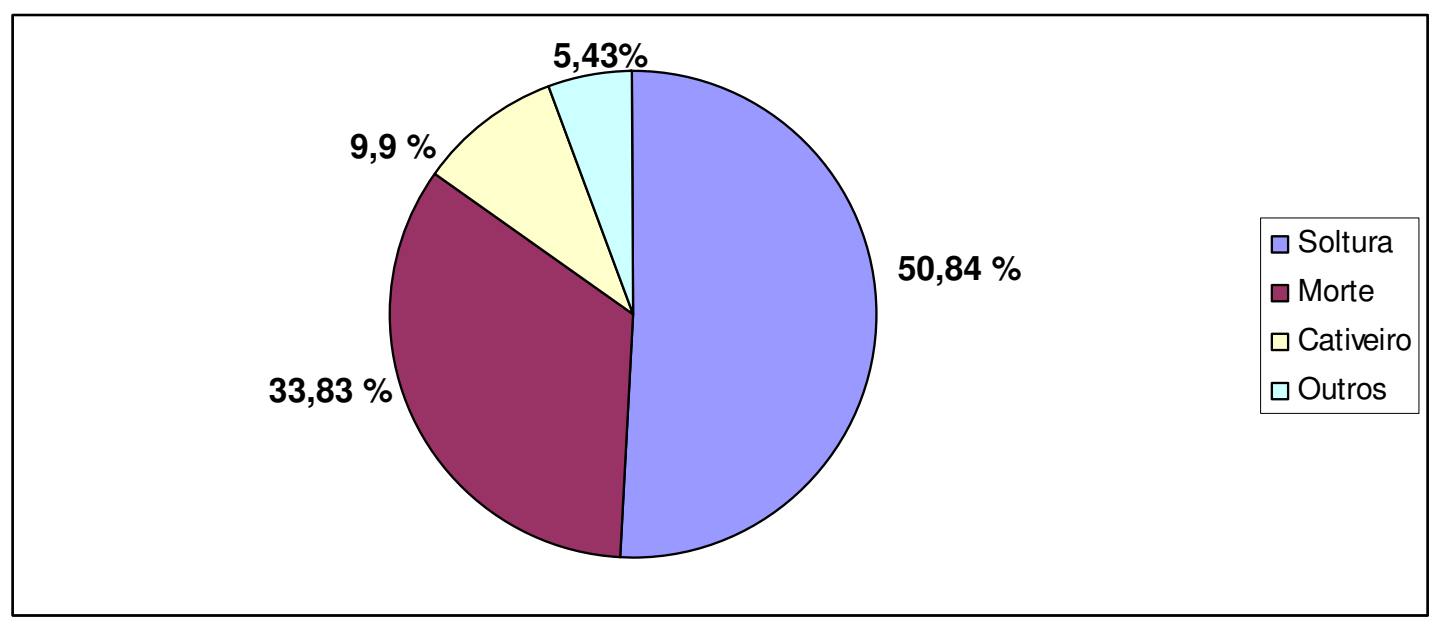

Fonte: DEPAVE- 3, 2008.

Nota:

Outros: Repatriamento, perdas; envio para o CCZ, pesquisa, ou ainda internados.

Nota-se que a soltura, seja por recolocação ou translocação, tem sido o destino dado à maioria dos animais recebidos, mesmo o DEPAVE-3 atendendo um grande número de animais apreendidos de outras regiões do País que não podem ser soltos. Isso reflete no número de animais que são destinados ao cativeiro, morrem ou têm outro destino.

Chama a atenção o elevado número de óbitos, demonstrando que mesmo quando assistidos por um serviço especializado, os animais chegam em péssimas condições de saúde decorrentes de lesões ou maus tratos, transporte realizado de maneira imprópria, além do stress que sofrem durante os procedimentos de manejo, mesmo que esses sejam voltados à recuperação da saúde do animal. 


\subsubsection{Monitoramento}

Para a avaliação de solturas, o monitoramento é uma ferramenta indispensável, porém, por exigir equipamentos sofisticados e onerosos e equipe de campo especializada, ele normalmente não é realizado pelas instituições.

O DEPAVE-3 adotou o sistema de monitoramento de aves silvestres com anilhas do Centro Nacional de Pesquisa para a Conservação das Aves (CEMAVE) de 1998 a 2004. A partir desse ano, passou a utilizar anilhas confeccionadas para a Prefeitura de São Paulo, que são empregadas nas aves que são recolocadas na natureza. $O$ anilhamento permitiu que a equipe aprimorasse o monitoramento das solturas e a obtenção de dados sobre a sobrevivência dos animais.

Entre outubro de 1998 a maio de 2005, foram anilhadas e soltas 3.854 aves. A taxa de recuperação foi de $2,2 \%$, das quais $52,4 \%$ eram rapinantes, ou seja, corujas, gaviões e falcões. Os outros 47,6\% foram, na grande maioria, passeriformes, seguidos por anseriformes, ciconiformes, psitaciformes, caprimulgiformes, coraciformes, piciformes, gruiformes, columbiformes, cuculiformes e apodiformes. (CARVALHO e NAMBA, 2006); (CARVALHO, 2007).

\section{Para CARVALHO (2008),}

Devido ao índice de sucesso de resgate, até o presente momento pode-se acreditar que as solturas realizadas com critérios técnicos e bem direcionados aprimoram a devolução das espécies que foram suprimidas pelo tráfico ou por ações antrópicas. Tais ações também estimulam a conservação de áreas verdes intactas e propiciam a abertura de novos caminhos junto à população para proteção e preservação da fauna” (p. 281).

Para as outras classes de animais são adotados outros sistemas de marcação para monitoramento, a partir de métodos preconizados para a espécie, como no caso dos mamíferos onde são empregados tatuagem e implantação de microchip. 
Para o bugio (Alouatta guariba clamitans), desde 1996 está sendo desenvolvido um projeto específico de recolocação (figura 9). Nove grupos de bugios, totalizando 24 indivíduos, foram soltos nas áreas remanescentes de Mata Atlântica no Município de São Paulo. Uma das evidências da contribuição do projeto para a sobrevivência da espécie traduz-se em 10 nascimentos ocorridos em cativeiro e outros dois nascimentos em vida livre (SUMMA et al., 2006). Atualmente, está sendo adotado o sistema de rádiotelemetria para o monitoramento da espécie.

Figura 9: Soltura de bugios (Alouatta guariba clamitans), após processo de reabilitação.

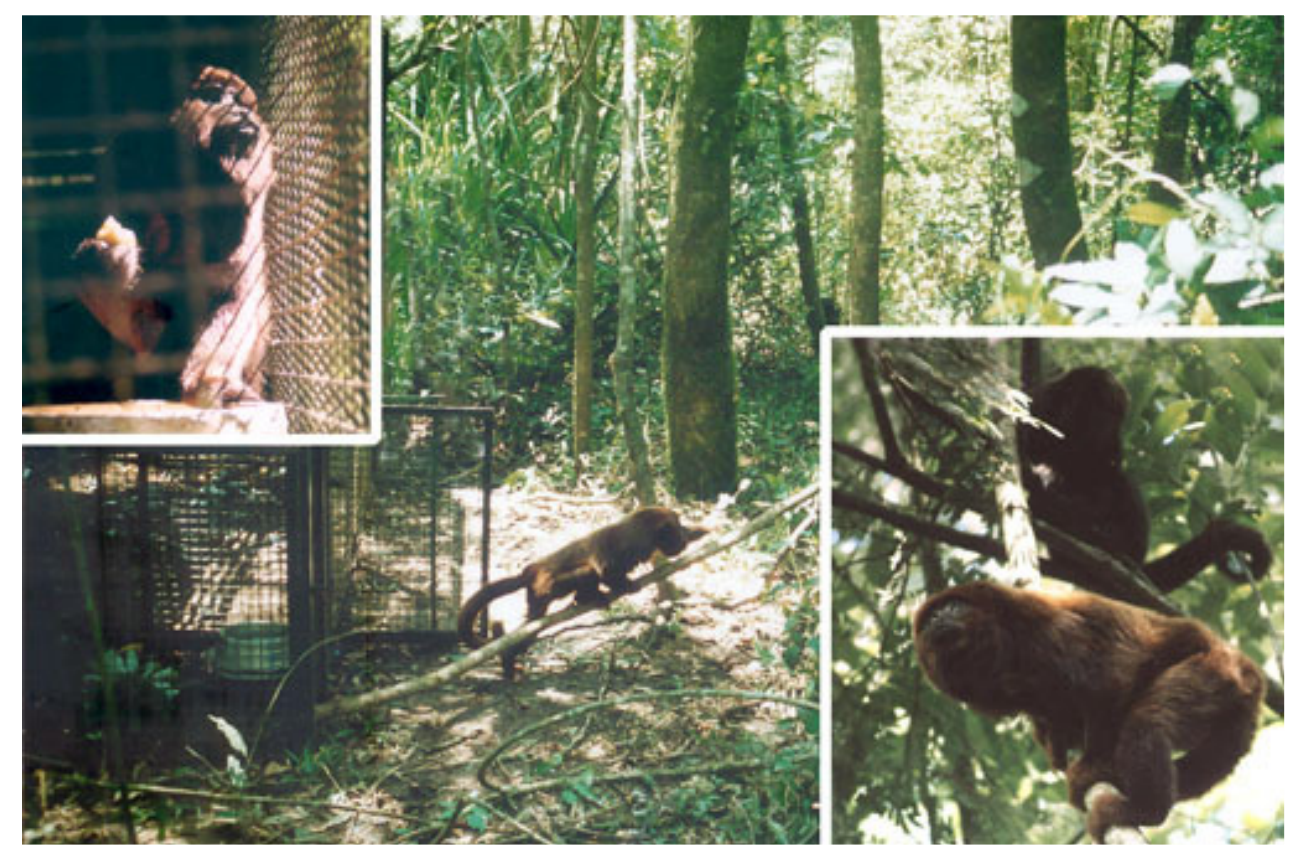

Fonte: Extraída de CBD (2008)

Elaborada por DEPAVE-3.

O monitoramento é a etapa final do processo que teve início com a entrada do animal no serviço e demonstra o sucesso do manejo realizado durante todas as etapas da internação, conforme ilustrado no fluxograma (figura 10). 
Figura 10 - Fluxograma do manejo de animais silvestres internados no DEPAVE-3.
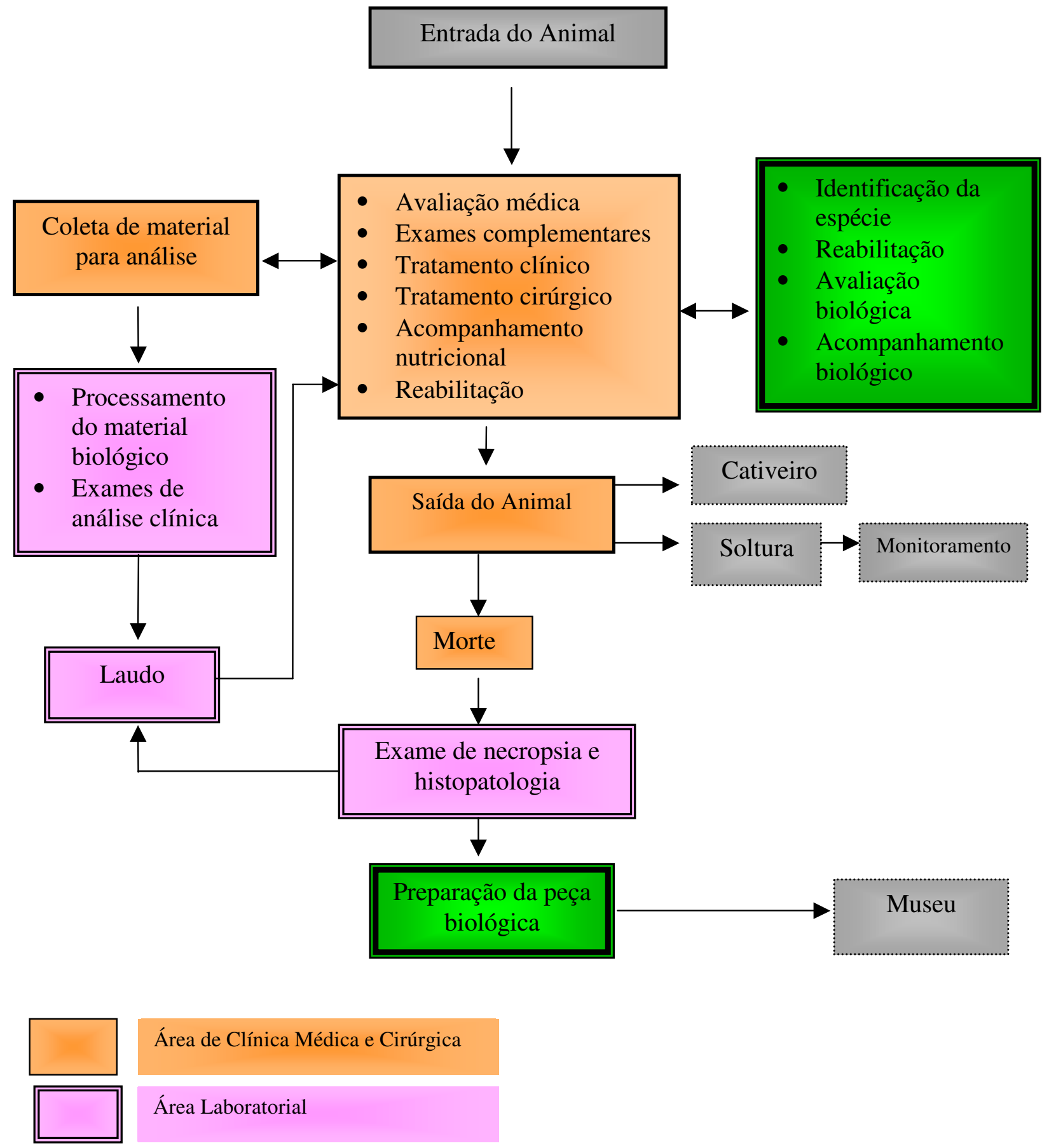

Área de Clínica Médica e Cirúrgica

Área Laboratorial

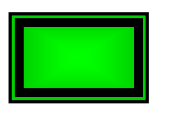

Área de Biologia e Nutrição

Fonte: Extraído de BRANCO (2002, p. 243)

Elaborada por Cristina Brites 


\subsubsection{Registro dos Dados}

Todas as informações colhidas durante o período de internação dos animais são registradas em fichas individuais apropriadas, que compõem o prontuário do animal. Esse prontuário pode ser composto pelas seguintes fichas: clínica, biológica, de reabilitação, de observação, laudos laboratoriais e exames complementares como raios $\mathrm{X}$, laudo de necropsia (figura 11); além de outros documentos que possam integrar o histórico do animal.

Figura 11 - Relação das fichas que compõem o prontuário de animais internados.

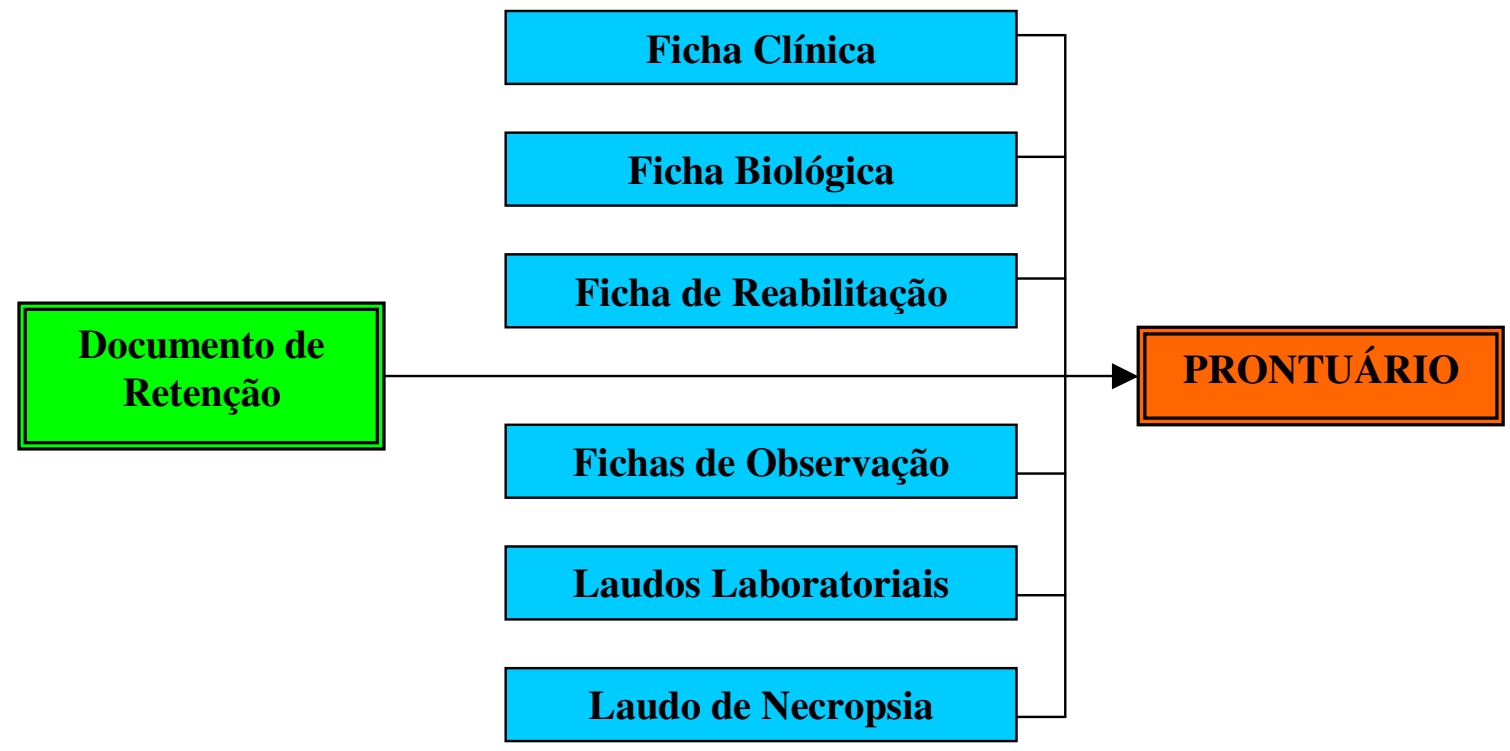

Fonte: DEPAVE-3

Elaborado pela autora

As informações referentes à entrada e à destinação dos animais são registradas na ficha de retenção e, parte dessas informações é transferida para o banco de dados denominado SISFAUNA ${ }^{36}$ - Sistema de Informações da Fauna (BRANCO, 2002).

\footnotetext{
${ }^{36}$ SISFAUNA - Sistema de Informações da Fauna, desenvolvido pelo Analista de Sistemas Natal Saito e pelas Médicas Veterinárias Angela Maria Branco e Maria Eugênia Laurito Summa, para o DEPAVE-3, em 1993.
} 
O Sistema é uma ferramenta que registra os dados relativos à entrada e à saída dos animais e é empregado para a elaboração de relatórios e pesquisas sobre a fauna atendida no DEPAVE-3. A partir dele, foi possível a criação de indicadores da fauna silvestre inseridos no GEO Cidade de São Paulo (PMSP; PNUMA; IPT, 2004).

\subsection{INDICADORES AMBIENTAIS PARA A FAUNA}

Segundo RIBEIRO (2002), no Brasil, a construção de indicadores de desenvolvimento sustentável foi inspirada no movimento internacional liderado pela Comissão para o Desenvolvimento Sustentável das Nações Unidas, que em 1996 publicou o "Livro Azul" Indicators of sustainable development: framework and methodologies, que perfaziam um total de 134 indicadores. No ano de 2000, esses indicadores foram reduzidos para apenas 57.

A construção de indicadores ambientais parte de um sistema de informações, que tem por finalidade melhorar o processo de tomada de decisões nas diferentes escalas governamentais, e possa reduzir os riscos ambientais, econômicos, entre outros, além de servir de base de apoio para o estabelecimento de políticas públicas adequadas para os problemas apresentados.

O GEO Cidades é um modelo de avaliação ambiental derivado do Projeto GEO (Global Environment Outlook), iniciado pelo PNUMA em 1995, com o objetivo de produzir a avaliação contínua do estado do meio ambiente global, regional e nacional, por meio de processos participativos e de parcerias institucionais (PMSP; PNUMA; IPT, 2004). Ele busca promover uma melhor compreensão da dinâmica das cidades e seus ambientes, fornecendo aos governos municipais, comunidade científica, formadores de opinião e ao público em geral, informação confiável e atualizada sobre as cidades, para ajudar a melhorar a gestão ambiental urbana (PNUMA, 2003).

O modelo GEO Cidades fundamenta-se na aplicação da estrutura de análise ambiental denominada PEIR (Pressão, Estado, Impacto e Resposta), adotada internacionalmente a partir do emprego e divulgação pela Organização para a Cooperação e Desenvolvimento Econômico (OCDE). 
Essa estrutura propicia a compreensão dos problemas e fenômenos urbanoambientais por meio da identificação e caracterização de indicadores ambientais e suas relações com os diferentes recursos ambientais envolvidos (ar, água, solo, biodiversidade e ambiente construído), configurando, então, a chamada matriz PEIR. (SVMA/IPT/PNUMA, 2004).

Os indicadores que caracterizam a Pressão sobre o meio ambiente se relacionam às atividades humanas e sua dinâmica, ou seja, às causas dos problemas ambientais.

Os indicadores de Estado dizem respeito às condições do ambiente que resultam dessas atividades.

Os indicadores de Impacto referem-se aos efeitos adversos à qualidade de vida, aos ecossistemas e à socioeconomia local.

Por fim, os indicadores de Resposta revelam as ações da sociedade no sentido de melhorar o estado do meio ambiente, bem como prevenir, mitigar e corrigir os impactos ambientais negativos decorrentes daquelas atividades (PMSP; PNUMA; IPT, 2004).

Os critérios para a seleção de indicadores ambientais abrangem a relevância política e utilidade para o usuário, consistência analítica, mensurabilidade, facilidade de compreensão, confiabilidade, transversalidade, universalidade e disponibilidade de dados (PMSP, 2004).

A partir do conjunto de 53 indicadores propostos na "cesta básica" do modelo GEO Cidades sugerido pelo Consórcio Parceria 21, o GEO da Cidade de São Paulo chegou ao total de 83 indicadores (figura 12). A matriz final foi aprovada pela Resolução CADES 82/2003, de 11 de dezembro de 2003. 
Figura 12 - Relação dos 83 indicadores ambientais propostos para a Cidade de São

Paulo, com destaque para os indicadores referentes à fauna silvestre.

\section{PRESSÃO}

P.01- Crescimento e densidade populacional P.02- Indice de desigualdade de renda (Gini) P.03- Indice de inclusăolexclusão social

P.04- Indice de desenvolvimento humano municipal (IDH-M)

P.05- Assentamentos autorizados e nāo autorizados

P.06- Expansão da área urbanizada

P.07- Verticalizaçăo de imóveis

P.08-Redução da cobertura vegetal

P.09- Consumo de água

P.10- Destinação de águas residuárias e pluviais

P.11- Produção de resíduos sólidos

P.12- Disposição de resíduos sólidos

P.13- Emissōes atmosféricas

P.14- Distribuição modal de transporte

P.15- Motorização

P.16- Consumo de combustiveis

P.17-Transmissāo de energia elétrica

P.18- Consumo de energla elétrica

P.19- Transmissões de radiodifusão

P.20- Uso de telefonia móvel

P.21- Atividades potencialmente poluidoras

P.22- Uso de agroquímicos

P.23- Ocorrências contra a fauna

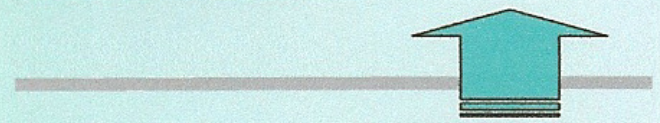

\section{RESPOSTA}

R.01- Plano Diretor Municipal

R.02- Legislação de proteção a mananciais

R.03- Agenda 21 local

R.04- Educação ambiental

R.05- Organizaçōes não-governamentais ambientalistas

R.06- Tributação ambiental

R.07- Controle de emissões atmosféricas

R.08- Controle de emissōes de fontes de ruído

R.09- Controle de circulação de cargas perigosas

R.10-Controle de vetores, fauna sinantrópica e animais soltos

R.11-Ligaçōes domiciliares

R.12- Áreas de risco de inundaçāo e escorregamento recuperadas

R.13- Áreas de erosão e assoreamento recuperadas

R.14- Reabilitaçäo de áreas degradadas

R.15- Investimentos em água e esgoto

R.16- Investimentos em gestão de resíduos sólidos

R.17- Recuperação de materiais recicláveis dos resíduos sólidos

R.18- Investimentos em transporte público

R.19- Ampliaçăo de cobertura vegetal

R. 20- Criaçāo e gestão de unidades de conservação

R.21- Reabilitação e soltura de animais silvestres

R.22- Sançōes por infraçōes a normas ambientais

\section{ESTADO}
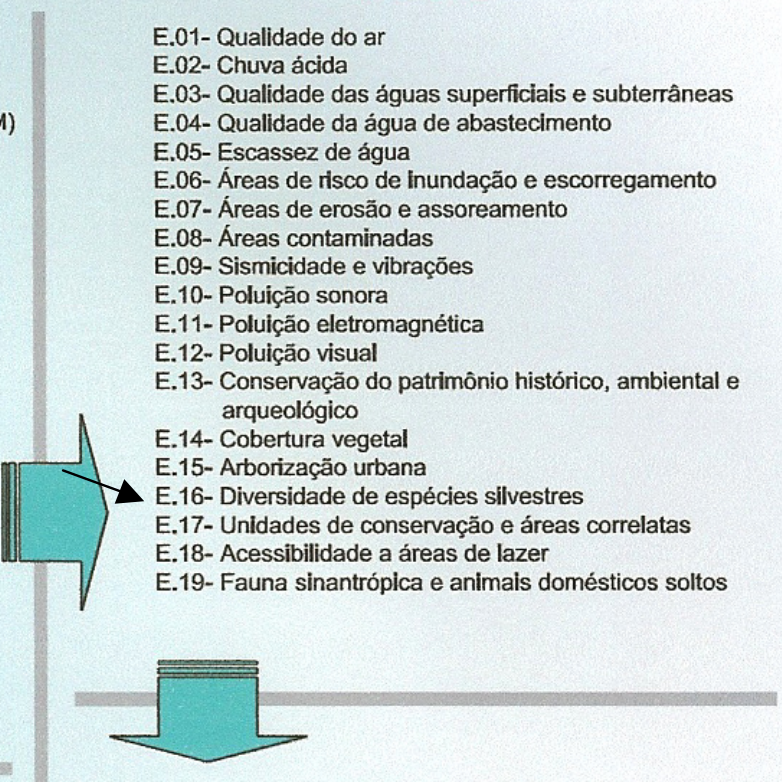

IMPACTO

I.01- Incidência de enfermidades associadas à poluição do ar 1.02- Óbitos decorrentes de enfermidades associadas à poluição do ar

1.03-Incidência de enfermidades de veiculação hidrica

1.04- Óbitos decorrentes de enfermidades de veiculação hídrica 1.05- Incidência de zoonoses

1.06- Óbitos decorrentes de zoonoses

1.07- Ocorrências de inundação e escorregamento

1.08- Áreas contaminadas com risco caracterizado à saúde

1.09- Alterações microclimáticas

1.10- Custos de captação, condução e tratamento de água

I.11- Rebaixamento do nivel d'água subterrâneo

1.12- Despesas com saúde pública devido a enfermidades associadas à poluiçăo do ar

I.13- Despesas com saúde pública devido a enfermidades de veiculação hídrica

I.14- Despesas com saúde pública devido a zoonoses

I.15- Despesas com conservação e restauração do patrimônio histórico, ambiental e arquelógico

I.16- Desvalorização imobiliária

I.17- Perda de atratividade urbana

I.18- Indice de vulnerabilidade juvenil

I.19- Perda de biodiversidade

Fonte: Extraída de GEO Cidade de São Paulo (SVMA; IPT; PNUMA, 2004). 
As questões relativas à fauna silvestre estão contempladas nos indicadores propostos de Pressão, Estado, Impacto e Resposta, principalmente devido às contribuições do DEPAVE-3 que, a partir dos dados contidos no SISFAUNA, pode propor os seguintes subindicadores: ${ }^{37}$

\section{1) Indicador de Pressão - (P-23) Ocorrências contra a fauna:}

a) Quantidade de indivíduos afetados ( $\left.\mathrm{n}^{\circ} / \mathrm{ano}\right)$.

2) Indicador de Estado - (E-16) Diversidade de espécies silvestres:

a) Quantidade total de espécies silvestres $\left(\mathrm{n}^{\circ}\right)$;

b) Proporção de espécies silvestres nativas (\%);

c) Proporção de espécies silvestres exóticas (\%);

d) Proporção de espécies silvestres exóticas invasoras $\left(\mathrm{n}^{\circ}\right)$.

\section{3) Indicador de Impacto - (I-19) Perda de biodiversidade:}

a) Quantidade de espécies ameaçadas da fauna (total por grupo taxonômico) para cada categoria de ameaça $\left(\mathrm{n}^{\circ}\right)$;

b) Diferença entre o número total de espécies ameaçadas da fauna (para cada categoria de ameaça), no momento atual $\left(t_{1}\right)$ em relação a um momento anterior $\left(t_{0}\right)$ $\left(n^{\circ}\right)$.

\section{4) Indicador de Resposta - (R-21) Reabilitação e soltura de animais silvestres:}

a) Proporção de indivíduos reabilitados (para cada grupo taxonômico), por ano (\%);

b) Proporção de indivíduos reabilitados e soltos na natureza (para cada grupo taxonômico), por ano (\%).

Isso significa que, devido aos trabalhos realizados pelo DEPAVE-3 e à sistemática atualização do SISFAUNA, os dados sobre a fauna silvestre estão contemplados nos Indicadores Ambientais Paulistanos, que visam avaliar o estado do meio e os impactos da degradação ambiental sobre a saúde pública e a qualidade de vida, bem como a eficácia das políticas públicas, para a tomada de decisões.

O único GEO que possui indicadores e subindicadores para a fauna silvestre é o da Cidade de São Paulo.

\footnotetext{
${ }^{37}$ PMSP. Secretaria do Verde e do Meio Ambiente; PNUMA; IPT. GEO Cidade de São Paulo: panorama do meio ambiente urbano. São Paulo, 2004.
} 


\subsection{COMUNICAÇÃO DE RESULTADOS DO TRABALHO}

Os serviços prestados pelos órgãos governamentais estão sob constante avaliação pela sociedade, que frente ao advento da criação de conselhos em diferentes setores da administração pública, passa a ter maior influência nas decisões de governo. Nesse sentido, a sociedade necessita estar constantemente informada sobre as questões públicas, mesmo que essas lhe pareçam bastante distantes de sua realidade.

Os trabalhos produzidos pelo DEPAVE-3 têm contribuído para a disseminação de informações sobre os animais silvestres, tanto para o público em geral como para os profissionais da área técnica, em forma de matérias para a imprensa rádiotelevisiva e escrita, publicações, palestras, cursos de capacitação, merecendo destaque os resultados decorrentes da produção de trabalhos acadêmicos e científicos ${ }^{38}$.

\subsubsection{Publicações, Cursos, Visitas Monitoradas ${ }^{39}$.}

Ao longo dos anos, e de acordo com as demandas, os resultados dos trabalhos passam a ser disponibilizados em forma de publicações de caráter informativo e técnico, que visam disponibilizar as informações ao público. Dentre essas produções podem ser destacadas:

- Livro: Fauna Silvestre - Quem são e onde vivem os animais na metrópole paulistana (2007);

- Livreto: Guia das Aves do Parque Ibirapuera (2006);

- Caderno da Biodiversidade (2005);

- Listas do Inventário da Fauna do Município de São Paulo (1998; 1999; 2000; 2006);

- Apostila de Procedimentos Gerais Referentes à Fauna dos Parques Municipais (2001);

\footnotetext{
${ }^{38}$ Informações contidas nos Relatórios Anuais da Divisão Técnica de Medicina Veterinária e Manejo da Fauna Silvestre, 1993 a 2003.

${ }^{39}$ Dados obtidos junto à Secretaria Municipal do Verde e do Meio Ambiente.
} 
- Manual de Observação das Aves (2002);

- Folder: A Fauna Silvestre da Cidade;

- Folder: O Gambá e o Meio Urbano;

- Folder: Cuidando de nossos amigos, os animais do Parque Ibirapuera;

- Folder: O que fazer quando encontrar filhotes de aves?

- Folder: São Paulo Wild Fauna - which are the animals and where they live in the metropolis.

Além dessas, outras publicações contam com artigos ou a participação de técnicos do DEPAVE-3, como:

- A Questão Ambiental Urbana: Cidade de São Paulo, PMSP (1993);

- SVMA. Que Sigla é Esta?, PMSP (1996);

- Atlas Ambiental do Município de São Paulo, PMSP (2004);

- GEO Cidade de São Paulo, PMSP; PNUMA; IPT (2004).

Devido à falta de oportunidades para profissionais adquirirem conhecimento na área de animais silvestres, comumente, técnicos do DEPAVE-3 ministram palestras e cursos a convite de instituições acadêmicas e científicas para tratarem e discutirem as questões relativas ao tema. Além desses eventos, o próprio DEPAVE-3 desenvolve cursos direcionados para funcionários da própria Prefeitura de São Paulo, e até mesmo para leigos no assunto, como:

- Procedimentos Gerais Referentes à Fauna dos Parques Municipais;

- Animais Silvestres, Domésticos e Sinantrópicos;

- Manejo e Contenção de Animais Silvestres;

- Observação de Aves.

Uma outra maneira empregada pelo DEPAVE-3 para apresentar os trabalhos realizados com a fauna se dá por meio de visitas monitoradas ${ }^{40}$, na sede do Parque Ibirapuera, onde o público pode tomar conhecimento de parte dos trabalhos e observar alguns animais em recuperação. No Parque Anhanguera, essa dinâmica não é adotada,

\footnotetext{
${ }^{40}$ PMSP. Secretaria do Verde e do Meio Ambiente. PROFAUNA: Programa de Manejo da Fauna Silvestre Interativo com a Cidade. São Paulo, 2001. CD-ROOM.
} 
uma vez que a maioria dos animais encontra-se em processo de reabilitação visando a sua recolocação na natureza, e o contato com humanos prejudica esse procedimento.

Uma outra forma de inteirar os usuários sobre os serviços prestados se dá por meio de campanhas, como EducaCão.

Ainda, no que tange a comunicação, um outro serviço oferecido pelo DEPAVE-3 disponibiliza um técnico para prestar esclarecimentos sobre animais silvestres, por telefone. As principais demandas são relativas à doação de animais por pessoas que querem se desfazer dos mesmos, solicitação para atendimento e remoção de animais silvestres; dúvidas quanto ao manejo, denúncias de maus tratos. Compete ao atendente, prestar esclarecimentos, orientar o solicitante e disponibilizar o serviço quando for pertinente ${ }^{41}$.

\subsection{EMPREGO DAS INFORMAÇÕES E DADOS}

As informações e dados gerados pelo DEPAVE-3 vem sendo amplamente empregados por empreendedores, órgãos ambientais e principalmente pela própria Secretaria do Verde e do Meio Ambiente na avaliação de Estudos de Impacto Ambiental (EIA), Relatórios de Impacto Ambiental (RIMA), e processos de licenciamento de obras.

O inventário da fauna é um referencial utilizado para a análise de processos administrativos, bem como para definir parâmetros de Termo de Ajustamento de Conduta (TAC), Termo de Compensação Ambiental (TCA) e multas. Esses instrumentos previstos em lei são empregados para mitigar, compensar ou punir atos que causam impactos negativos para o meio, nele, inserida a fauna ${ }^{42}$.

Porém, essas informações não têm sido empregadas apenas para repressão ou aplicação de sanções, mas também para a criação de parques e unidades de conservação. Como exemplo, a criação da APA Municipal Capivari-Monos, com $251 \mathrm{Km}^{2}$, onde a

\footnotetext{
${ }^{41}$ Atividades descritas nos Relatórios Anuais da Divisão Técnica de Medicina Veterinária e Manejo da Fauna Silvestre.

${ }^{42}$ Procedimento adotado pelo Departamento de Controle da Qualidade Ambiental (DECONT), da Secretaria Municipal do Verde e do Meio Ambiente.
} 
comprovação da ocorrência da onça-parda (Felis concolor) na região foi usada como um importante argumento para a defesa da fauna, constando entre os objetivos da Lei Municipal $n^{\circ} 13.136 / 2001$ :

- Art. $3^{\circ}$, Inciso II - proteger a biodiversidade;

- Art. 17 - Fica proibida a coleta ou apreensão de animais silvestres no interior da APA Capivari-Monos, bem como a soltura de espécies animais exóticas.

Os dados sobre a fauna da Cidade de São Paulo também foram inseridos por técnicos do DEPAVE-3 no Sistema de Informação Ambiental (SinBiota), do Programa BIOTA, da Fundação de Amparo à Pesquisa do Estado de São Paulo (FAPESP), que tem por objetivo catalogar e integrar informações sobre a biodiversidade do Estado de São Paulo ${ }^{43}$. Assim, o Estado também dispõe de informações do município para empregar em seus programas ambientais.

Dessa forma, a municipalidade pode contar com mais informações de diagnóstico do meio para subsidiar o planejamento da cidade e suas ações.

Com relação aos dados gerados pelos setores de clínica médica e medicina preventiva, esses podem estar diretamente ligados à saúde da população. Os exames para diagnóstico de doenças como a raiva, leptospirose, toxoplasmose, hantavirose, malária, revelam que os animais silvestres que dão entrada no serviço podem ser portadores de agentes causadores de zoonoses, que podem afetar drasticamente a saúde do homem. Nesse sentido, vários trabalhos de pesquisa estão sendo realizados por intermédio dos animais atendidos no DEPAVE-3.

\subsection{CONTRIBUIÇÃO ACADÊMICA E CIENTÍFICA}

No DEPAVE-3, a imprevisibilidade com relação à espécie que será atendida e o quadro que o animal apresentará, tem possibilitado o desenvolvimento técnico da equipe, que mescla aprendizado e experiência, compartilhando essa prática com estagiários principalmente das áreas de Biologia e Medicina Veterinária.

\footnotetext{
${ }^{43}$ FAPESP. Biota. São Paulo. Disponível em: <http://sinbiota.cria.org.br/sia/index>. Acesso em: 19 fev. 2007.
} 
Desde a criação do serviço, 158 vagas $^{44}$ de estágio com duração de 1 ou 2 anos foram preenchidas por estudantes universitários, possibilitando que alunos aprendessem a manejar animais silvestres, partindo da prática.

Dos 158 acadêmicos que realizaram estágio no DEPAVE-3, 110 pertenciam à área das Ciências Biológicas, enquanto 46 de Medicina Veterinária. Duas outras vagas foram ocupadas por um estagiário de Pedagogia e um de Geografia.

Dos 110 alunos das Ciências Biológicas, 74,5\% foram contratados pelo período de 1 ano e 25,5\% pelo período de 2 anos. Dos 46 alunos de Medicina Veterinária, 78,3\% foram contratados por 1 ano e $21,7 \%$ por 2 anos.

A longa duração do estágio possibilita que os alunos adquiram conhecimento e se capacitem para atuarem na área de animais silvestres, que oferece poucas oportunidades para aprendizado, além de adquirirem familiaridade com o serviço, podendo assumir responsabilidades e cooperar nos trabalhos técnicos.

Uma outra característica do serviço diz respeito à necessidade de diagnóstico das doenças dos animais atendidos. Por contar com poucos meios para diagnóstico laboratorial, a maior parte do material coletado é encaminhado para análise em laboratórios particulares ou públicos. Esses últimos, face ao caráter de instituições de pesquisa, como institutos e universidades, além de fornecerem os dados sobre a análise do material, em alguns casos, também realizam trabalhos acadêmicos de pesquisa, a partir deles. Há casos de demandas induzidas, onde o pesquisador solicita aos técnicos do DEPAVE-3 a coleta de material específico para a sua pesquisa.

Dessa forma, tanto a equipe do DEPAVE-3 é beneficiada pela informação que necessita a respeito do animal para oferecer-lhe o tratamento mais adequado, como o pesquisador pela obtenção do material para a sua pesquisa.

Nesse sentido, alguns exemplos de pesquisas realizadas a partir de material biológico de animais silvestres atendidos no DEPAVE-3 (quadro 6), demonstram que os animais vitimados podem contribuir para o a avanço nas pesquisas da medicina veterinária e biologia de animais silvestres, ainda pouco exploradas no Brasil. Esses

\footnotetext{
${ }^{44}$ Fonte: Coordenadoria Geral de Estágios da Divisão de Desenvolvimento de Pessoal da SVMA, 2008.
} 
exemplos tratam de trabalhos apresentados em congresso, teses de mestrado ou doutorado, publicação de trabalho científico ${ }^{45}$.

Quadro 6 - Exemplos de pesquisas e trabalhos científicos que tiveram contribuição de material biológico, decorrente do manejo de animais silvestres, pelo DEPAVE-3.

\begin{tabular}{|l|l|}
\hline \multicolumn{1}{|c|}{ Título do Trabalho } & \multicolumn{1}{|c|}{ Autores } \\
\hline $\begin{array}{l}\text { Prevalência de anticorpos anti-rábicos neutralizantes } \\
\text { em animais silvestres terrestres da Cidade de São } \\
\text { Paulo. }\end{array}$ & ALMEIDA, M. F. (1998) \\
\hline $\begin{array}{l}\text { Anticorpos anti-Toxoplasma gondii em animais } \\
\text { silvestres encaminhados ao DEPAVE-3 (São Paulo- } \\
\text { SP), no período de abril de 1995 a março de 1999. }\end{array}$ & SILVA, J. C. R et al. (2000) \\
\hline $\begin{array}{l}\text { Prevalência de anticorpos anti- Leptospira } \\
\text { interrogans em répteis silvestres encaminhados ao } \\
\text { DEPAVE-3 (São Paulo-SP), no período de janeiro de } \\
\text { 1998 a março de 2001. }\end{array}$ & \\
\hline $\begin{array}{l}\text { Estudo da prevalência de anticorpos anti Leptospira } \\
\text { em gambás (Didelphis sp) recebidos pela Divisão } \\
\text { Técnica de Medicina Veterinária e Manejo da Fauna } \\
\text { Silvestre -DEPAVE-3 (SVMA), no período 1996 a } \\
\text { 1999. }\end{array}$ & \\
\hline $\begin{array}{l}\text { Genetic diversity in different populations of sloths } \\
\text { assessed by DNA fingerprinting. ( }\end{array}$ & MORA, L. R. et al. (2001) \\
\hline $\begin{array}{l}\text { Contribuição ao estudo da hepatite A em primatas } \\
\text { neotropicais. (*) }\end{array}$ & SETZER, A. P. (2003) \\
\hline
\end{tabular}

\footnotetext{
${ }^{45}$ Relatórios Anuais da Divisão Técnica de Medicina Veterinária e Manejo da Fauna Silvestre. (") Trabalhos encontrados no site Google Acadêmico pesquisando a palavra depave 3. Disponível em: <http://scholar.google.com.br/schhp?hl=pt-BR>. Acesso em: 8 mai. 2008.
} 


\begin{tabular}{|c|c|}
\hline $\begin{array}{l}\text { Characterization of Monkey Enteropathogenic } \\
\text { Escherichia coli (EPEC) and Human Typical and } \\
\text { Atypical EPEC Serotype Isolates from Neotropical } \\
\text { Nonhuman Primates. }(*)\end{array}$ & $\begin{array}{l}\text { CARVALHO, V. M. et al. } \\
(2003)\end{array}$ \\
\hline $\begin{array}{l}\text { Pathology of Toxoplasmosis in Captive New World } \\
\text { Primates. }(*)\end{array}$ & EPIPHANIO, S. et al. (2003) \\
\hline $\begin{array}{l}\text { Estudo da leptospirose (Leptospira } s p \text { ) em gambás } \\
\text { (Didelphis aurita e D. albiventris) no Município de } \\
\text { São Paulo, período de } 1995 \text { a } 2003 \text {. }\end{array}$ & BERTOLA, (2004) \\
\hline Vigilância epidemiológica da hantavirose no Brasil. & PEREIRA, L. E. (2004) \\
\hline $\begin{array}{l}\text { Description of the larva of Amblyomma longirostre } \\
\text { (Koch, 1844) (acari: ixodidae) by light and scanning } \\
\text { electron microscopy. }(*)\end{array}$ & $\begin{array}{l}\text { BARROS-BATTESTI, D. M. et } \\
\text { al. (2005) }\end{array}$ \\
\hline $\begin{array}{l}\text { Cytochrome B sequences show subdivision between } \\
\text { populations of the brow howler monkey (Alouatta). } \\
(*)\end{array}$ & HARRIS, E. E. et al. (2005) \\
\hline $\begin{array}{l}\text { Estimativa do tamanho populacional do lagostim } \\
\text { exótico Procambarus clarkii (Girard) (Crustacea, } \\
\text { Decapoda, Cambaridae) no Parque Municipal } \\
\text { Alfredo Volpi, São Paulo, Brasil. (*) }\end{array}$ & $\begin{array}{l}\text { SILVA, H. L. M.; BUENO, S. L. } \\
\text { S. (2005) }\end{array}$ \\
\hline $\begin{array}{l}\text { Widespread occurrence of antibodies against } \\
\text { circumsporozoite protein and against blood forms of } \\
\text { Plasmodium vivax, P. falciparum and P. malariae in } \\
\text { Brazilian wild monkeys. }\left(^{*}\right)\end{array}$ & $\begin{array}{l}\text { DUARTE, A. M. R. C. et al. } \\
(2006)\end{array}$ \\
\hline $\begin{array}{l}\text { Estudo ecoepidemiológico de hantavírus em roedores } \\
\text { das regiões da Mata Atlântica e Cerrado do Brasil. }\end{array}$ & PEREIRA, L. E. (2006) \\
\hline $\begin{array}{l}\text { Anticorpos para Borrelia burgdorferi em indivíduos } \\
\text { que trabalham com animais silvestres. }\end{array}$ & CORRADI, D.A. (2006) \\
\hline
\end{tabular}




\begin{tabular}{|l|l|}
\hline $\begin{array}{l}\text { Polyphyly of the hawk genera Leucopternis and } \\
\text { Buteogallus (Aves, Accipitridae): multiple habitat } \\
\text { shifts during the Neotropical buteonine } \\
\text { Diversification. }\left(^{*}\right)\end{array}$ & AMARAL, F. S. R. et al. (2006) \\
\hline $\begin{array}{l}\text { Comparative Phylogeography of the Atlantic Forest } \\
\text { Endemic Sloth (Bradypus torquatus) and the } \\
\text { Widespread Three-toed Sloth (Bradypus variegates) } \\
\text { (Bradypodidae, Xenarthra). (*). }\end{array}$ & MORAES-BARROS, N. et al. \\
\hline $\begin{array}{l}\text { Rickettsia infection in five areas of the state of São } \\
\text { Paulo, Brazil. (*) }\end{array}$ & HORTA, M. C. et al. (2007) \\
\hline $\begin{array}{l}\text { O bugio Alouatta guariba clamitans (Primates - } \\
\text { Atellidae) como indicador da pressão ambiental na } \\
\text { Região Metropolitana de São Paulo. }\end{array}$ & SUMMA, M. E. L. et al. (2007) \\
\hline
\end{tabular}

Como resultados da gestão e do manejo da fauna silvestre podem ser considerados os benefícios para os espécimes animais atendidos; o avanço na área de pesquisa médica a partir da análise de materiais biológicos coletados; o conhecimento gerado durante a realização das práticas de manejo com os animais e a criação de indicadores ambientais para a fauna silvestre. $\mathrm{O}$ que pode ser observado nesse processo é que dele se beneficiam:

- os animais que têm seu sofrimento minimizado ou abolido;

- os profissionais da área ambiental pela oportunidade de trabalho e aprendizado;

- as instituições e os cidadãos que se utilizam dos serviços oferecidos.

Também, o meio natural pode ser beneficiado, caso as ocorrências envolvendo os animais silvestres que chegam para atendimento sejam utilizadas para averiguação de crimes ambientais como os desmatamentos e as queimadas (BRANCO, 2007). 


\section{DISCUSSÃO E CONCLUSÕES}

Considerando autores como Odum, para quem as soluções dos problemas ambientais devem estar pautadas na preocupação com o nível de organização dos ecossistemas; Sobral, para quem o ambiente urbano difere do ecossistema natural e são as cidades as maiores propulsoras de impactos causados pelo homem na natureza; e ainda, Ojasti, para quem os serviços de fauna são vitais frente à expansão demográfica, é nas cidades, que representam sistemas ecológicos complexos e dinâmicos, onde o estudo da fauna pode trazer contribuições para as áreas de meio ambiente e saúde.

O Brasil vem perdendo sua rica biodiversidade devido ao processo de desenvolvimento do País, que provoca grandes transformações no meio natural para atender as demandas humanas por habitação, alimentação, mobilidade e obtenção de renda. Esse processo é particularmente cruel para a flora e fauna silvestres, que acabam sucumbindo pela transformação do meio.

Porém, muitos animais, mesmo próximos dos aglomerados humanos, conseguem adaptar-se e manter uma população que garanta a sobrevivência da espécie e a manutenção da cadeia biológica. No entanto, essa proximidade propicia que animais sejam constantemente vitimados pela pressão antrópica.

A maioria desses animais morre, sem que o homem tome conhecimento. Porém, alguns acabam sendo resgatados e, dependendo da espécie e do tipo de vitimação, são mortos para fins de alimentação ou utilização de partes; outros, que são socorridos, acabam sendo vendidos ou aprisionados, mesmo sendo todos esses atos contrários à legislação.

Face ao caráter educativo da legislação ambiental e à sua constante divulgação, algumas pessoas, quando resgatam animais silvestres vitimados, procuram depositá-los em locais que prestem socorro, porém esses são praticamente inexistentes no País. Por essa razão, algumas entidades de proteção animal, mesmo não autorizadas e estruturadas para esse fim, acabam sendo procuradas pelo caráter protecionista.

Nas cidades, alguns animais são indiretamente vitimados pela simples ocupação humana, porém, outros, segundo a WWF-Brasil e a RENCTAS, são capturados na 
natureza para a venda no comércio ilegal, cujas ações repressivas cabem aos órgãos de polícia, tanto a civil, militar e federal, além de outros órgãos de fiscalização. Os animais apreendidos devem ser depositados em instituições autorizadas pelo IBAMA, porém, frente à inexistência e indisponibilidade de locais apropriados para esta finalidade, a maioria é solta sem critério.

Durante a pesquisa foram identificadas entidades que atendem animais, na sua grande maioria, apreendidos pelos órgãos de fiscalização. Foi constatado que, mesmo alguns centros de triagem, parceiros do IBAMA, ainda funcionam de maneira informal dentro de instituições públicas, pela falta de instrumento legal que reconheça sua existência e estrutura de funcionamento.

Na Região Neotropical, segundo autores como Drews, Clark Jr., Hoyt, entre outros, o panorama é semelhante ao que ocorre no Brasil. O Governo, apesar de ter mecanismos legais para regular e controlar os assuntos relativos à fauna silvestre, acaba transferindo a responsabilidade sobre os animais vitimados para os agentes ambientais, zoológicos, criadouros e entidades não governamentais. Jiménez-Perez e Drews apontam os problemas da gestão dos centros de resgate que trabalham com grandes dificuldades financeiras, falta de pessoal qualificado, além da inexistência de normas técnicas para a realização dos trabalhos voltados para a recolocação de animais na natureza.

Face ao problema, este trabalho teve como objetivo pesquisar o tema e testar a hipótese se o Estado, nas suas diferentes esferas de governo, deve ser aparelhado para fazer a gestão e o manejo da fauna silvestre nativa, em seu território.

Por essa razão, foi realizado um estudo de caso sobre a Prefeitura da Cidade de São Paulo, que possui em sua estrutura de governo um serviço voltado a promover a conservação e a preservação da fauna da Cidade.

Com relação às políticas públicas, a Prefeitura de São Paulo criou, através de leis municipais, tanto a Divisão Técnica de Medicina Veterinária e Manejo da Fauna Silvestre (DEPAVE-3), como os Centros de Reabilitação e de Triagem de Animais Silvestres (CRAS e CETAS), subordinados a essa Divisão, com atribuições que garantem a gestão da fauna silvestre em seu território. O DEPAVE-3 está subordinado 
ao Departamento de Parques e Áreas Verdes (DEPAVE), da Secretaria Municipal do Verde e do Meio Ambiente (SVMA).

No decorrer dos anos, o DEPAVE-3 tem atualizado e ampliado o inventário da fauna da Cidade, que apesar de conter apenas dados qualitativos, configura um importante instrumento de planejamento ambiental, subsidia todas as recolocações de animais, além de instrumentalizar técnicos das áreas de licenciamento e fiscalização da própria Prefeitura. O inventário, que lista 435espécies de animais, indica que a Cidade ainda possui extensas áreas preservadas de Mata Atlântica e um Sistema de Áreas Verdes que garante a sobrevivência de animais silvestres, mesmo nas regiões bastante habitadas, traduzindo certa qualidade ambiental para os seus moradores.

A partir do inventário faunístico e atendimento de animais vitimados, é possível realizar uma série de estudos sobre a dinâmica do crescimento da cidade e o impacto gerado sobre fauna, fazendo com que os animais sejam considerados como bioindicadores.

Dessa forma, o atendimento de animais atropelados, eletrocutados, queimados, envenenados, doentes, refletem o que está ocorrendo no ambiente, a exemplo do relato de Clark Jr. sobre uma águia calva, vítima de atropelamento por ter sido intoxicada com pesticida empregado na lavoura, e que culminou na proibição do uso do produto. Também, a pesquisa médica pode detectar doenças que acometem os animais silvestres, domésticos e o homem.

Considerando as pesquisas das doenças que podem afetar a população humana, como as citadas por Nogueira Neto em 1973, e as recentemente compiladas por Silva, os serviços de fauna podem prestar grande contribuição à área de saúde pública, uma vez que os animais silvestres passam a ser sentinelas epidemiológicos naturais, principalmente nas cidades, onde aumenta a preocupação com os riscos das doenças emergentes e reemergentes.

Nesse contexto, a investigação de doenças nos animais silvestres passa a ser uma ação inovadora que visa promover a saúde e o bem estar da comunidade e do meio ambiente. 
A preocupação com os riscos à saúde humana pela proximidade ou convívio com animais silvestres é uma questão de saúde pública que, desde os seus primórdios, sempre esteve direcionada ao controle de vetores, de animais peçonhentos e de reservatórios ou hospedeiros de doenças como a raiva.

Diversas pesquisas médicas e biológicas vêm sendo realizadas em materiais biológicos colhidos de animais silvestres resgatados, comprovando que diversas doenças encontram-se no ambiente natural, nas populações silvestres. Isso possibilita a atuação dos órgãos de vigilância ambiental em saúde, quando constatada a ocorrência de uma zoonose em animais silvestres, a exemplo dos casos mencionados envolvendo morcegos positivos para a raiva e que habitavam parques urbanos da Cidade de São Paulo.

Dessa forma, os serviços voltados ao atendimento de animais silvestres devem ser estruturados para contribuir na investigação de doenças que acometem os animais e podem ser transmitidas ao homem, atuando como um órgão de apoio à vigilância ambiental em saúde, por proporcionar conhecimento e possibilitar a detecção de fatores do meio ambiente que interferem na saúde humana, podendo recomendar medidas de prevenção e controle, como no caso das doenças presentes nos animais que vivem na cidade.

Além de diagnosticar doenças e tratar os animais, a equipe do DEPAVE-3 atua para viabilizar sua recolocação na natureza, conforme determina a legislação ambiental brasileira e preconiza autores como Jiménez-Peres, Hérnandez, Drews, Branco, Clark Jr., desde que o animal seja atendido em um serviço estruturado para essa finalidade, frente aos riscos de solturas realizadas sem critérios técnicos.

No Brasil, a maioria dos centros denominados de CETAS atua no recebimento de animais apreendidos em ações de fiscalização, e não no atendimento de animais vitimados, como faz o DEPAVE-3 que consegue manter um índice de soltura acima de $50 \%$ para os animais silvestres atendidos.

O monitoramento dessas solturas é realizado basicamente pelo sistema de marcação preconizado para a espécie, com exceção dos bugios, em que a técnica de rádiotelemetria já vem sendo empregada, demonstrando um aprimoramento nesse procedimento. 
Os animais que não atendem os critérios preconizados para soltura são destinados para cativeiros, após a liberação da guia de transporte pelo IBAMA, garantindo que o órgão executor da política nacional destine os animais somente para entidades autorizadas.

O SISFAUNA é uma ferramenta que dá transparência ao serviço e possibilita a consulta de dados de todo animal atendido, com a emissão de relatórios. Esse sistema também propiciou a criação dos indicadores de fauna no GEO- Cidade de São Paulo, demonstrando que os dados obtidos são relevantes e confiáveis, além de possibilitar a avaliação do serviço ao longo dos anos.

O DEPAVE-3 tem uma característica de "hospital escola". Tanto os profissionais contratados quanto os estudantes de Biologia e Medicina Veterinária têm a oportunidade de aprender a partir do manejo da fauna silvestre, de diferentes espécies, com diferentes problemas de saúde, e que exigem um grande esforço da equipe para o sucesso do tratamento e da reabilitação, expressos principalmente no ato de soltura dos animais.

Por se tratar de uma Divisão na estrutura do governo municipal, o DEPAVE -3 possui dotação orçamentária própria, para o atendimento das despesas decorrentes do funcionamento específico do serviço.

O número de funcionários permite que as atribuições sejam realizadas de forma satisfatória, considerando as especificidades dos trabalhos e qualificação dos profissionais. Os adicionais salariais servem de incentivo para os funcionários que têm ciência dos riscos decorrentes do manejo de animais silvestres e das doenças.

O risco de transmissão de doenças entre os animais e de zoonoses existe, porém, pode ser minimizado com a construção de uma nova estrutura hospitalar que garanta melhores condições de tratamento e alojamento para os animais e bem-estar dos funcionários. A construção do hospital também irá propiciar a melhoria das visitas monitoradas com finalidade educativa, ampliando a atuação da equipe na disseminação de informações para diferentes públicos.

Interessante observar que, a partir de históricos isolados de atendimentos de animais vitimados, quando essas informações se transformam em dados, trazem uma grande contribuição, seja para as espécies animais, mas também para as áreas de meio 
ambiente e saúde, a exemplo de alguns trabalhos acadêmicos apresentados no quadro 6 , e demais publicações.

Com dados, o governo possui instrumentos para tomada de decisões que vão desde avaliação sobre a criação de uma unidade de conservação, assim como a implantação de empreendimentos impactantes para o meio natural, e até o posicionamento com relação a questões como: controle de espécies invasoras; abate de manejo; caça; venda de animais silvestres como pet. Atualmente, as discussões sobre essas questões são norteadas ora por visões humanitárias, ora utilitaristas, devido à falta de informações.

Através do estudo de caso, pode ser demonstrado que a Prefeitura de São Paulo, ao criar o DEPAVE-3, passou a:

- Cumprir a legislação ambiental referente à fauna;

- Disponibilizar um serviço público para atendimento de demandas sobre fauna silvestre;

- Assumir a responsabilidade na gestão da fauna;

- Conhecer a fauna do seu território;

- Obter informações e dados importantes para a gestão ambiental e planejamento da cidade;

- Conhecer as doenças presentes na fauna silvestre de vida livre;

- Desenvolver técnicas para a recolocação de animais vitimados na natureza;

- Contribuir com material para pesquisa;

- Formar profissionais especializados no manejo de animais silvestres;

- Publicar os resultados decorrentes dos trabalhos realizados.

Baseando-se em considerações de autores como Ojasti, sobre os aspectos da gestão da fauna, Kleiman, Gaughley e Gunn sobre a conservação das espécies; Grandy, sobre a profissionalização do trabalho; e ainda, Clark Jr. sobre o potencial para programas educativos dos serviços de fauna, podemos concluir que a Prefeitura da Cidade de São Paulo é a única do País que efetivamente realiza a gestão da fauna silvestre em seu território. O serviço cumpre a legislação com critérios técnicos e ainda 
oferece atendimento aos animais vitimados das cidades vizinhas, face à falta de serviços da mesma natureza na região.

Durante a pesquisa não foi identificada outra entidade pública que tenha assumido a gestão da fauna, com toda a sua complexidade, da forma que vem sendo realizada na Cidade de São Paulo.

O grande diferencial da Prefeitura de São Paulo foi ter criado um serviço voltado prioritariamente ao atendimento de animais silvestres vitimados em seu território, e não de animais apreendidos pelos órgãos de fiscalização. O conhecimento da procedência do animal e adoção de critérios para a soltura possibilitam que o mesmo seja reintegrado na natureza, liberando espaço para o atendimento de outros animais vitimados.

Outra característica foi o serviço ter sido estruturado, conforme descrito nas atribuições, para realizar o manejo da fauna silvestre na cidade, uma vez que o critério adotado para a recolocação de animais silvestres resgatados na natureza exige o conhecimento do meio, tanto das espécies que ocorrem na cidade como das doenças presentes no meio.

A gestão da fauna não deve ser entendida como um trabalho de caráter protecionista, voltado à solução de problemas de alguns espécimes de animais vitimados, e sim, como um serviço estratégico para orientar o planejamento e as ações voltadas à conservação e preservação de áreas naturais e à implantação de áreas verdes, que garantam a maior biodiversidade no ambiente urbano, além de possibilitar o controle do estado de saúde dos animais e conhecimento das zoonoses que podem acometer a população humana.

Considerando a legislação vigente, as contribuições dos autores mencionados, os problemas relativos à fauna, e os resultados obtidos pela Prefeitura de São Paulo, entendo que a hipótese: "O Estado, nas suas diferentes esferas de governo, deve ser aparelhado para fazer a gestão e o manejo da fauna silvestre nativa, em seu território" é verdadeira, porém, merece algumas considerações:

1) Assumir a gestão da fauna silvestre requer da instituição uma grande capacidade financeira para arcar com os custos do serviço que, frente à alta 
complexidade, é bastante oneroso, principalmente quanto às instalações, equipamentos e pessoal necessários;

2) É necessário contar com instituições de pesquisa e ensino próximas ao serviço e buscar formalizar parcerias com essas instituições;

3) É imprescindível que o serviço de gestão e manejo da fauna, independente da denominação, seja instituído por política pública que garanta a sua estruturação, operação e continuidade.

Dessa forma, não basta construir algumas instalações e contratar uma pequena equipe para responder pelos animais silvestres resgatados. A gestão da fauna exige um grande compromisso do Poder Público, que pode ser revertido para o bem estar da população, quando essa toma conhecimento e se conscientiza da sua importância. 


\section{RECOMENDAÇÃO}

Que as capitais de estado e as principais cidades do País, integrantes do SISNAMA, criem políticas públicas e assumam a gestão da fauna silvestre nativa de seu território, criando serviços voltados ao manejo de animais silvestres resgatados na região, a exemplo da Cidade de São Paulo.

Essa medida possibilitaria que um maior número de animais vitimados, também pelo comércio ilegal, fosse reintegrado ao meio natural quando repatriados ao estado de origem. 


\section{REFERÊNCIAS}

ALIÓ, L. W. Venezuela: marco administrativo y legal de la rehabilitación y liberación de fauna. In: DREWS, C. (Ed.). Rescate de fauna em el Neotrópico. Heredia: Euna, 1999. p. 311-324.

ALMEIDA, A. F. et al. Levantamento da avifauna da Região Metropolitana de São Paulo atendida pela Divisão Técnica de Medicina Veterinária e Manejo da Fauna Silvestre. Boletim CEO, São Paulo, n. 15, p. 17-26, 2003.

APRILE, G.; BERTONATTI, C. Argentina: antecedentes y perspectivas de la rehabilitación de fauna silvestre. In: DREWS, C. (Ed.). Rescate de fauna em el Neotrópico. Heredia: Euna, 1999. p. 109-133.

BERTOLA, P. B. Estudo da leptospirose (Leptospira sp) em gambás (Didelphis aurita e D. albiventris) no Município de São Paulo no período de 1995 a 2003. 2004, 88 p. Dissertação (Mestrado em Medicina Veterinária) - Faculdade de Medicina Veterinária e Zootecnia, Universidade de São Paulo, São Paulo.

BRANCO, A. M. Centro de Manejo de Animais Silvestres. In: GIOVANINI, D. (Org.). Animais silvestres: vida à venda. Brasília, DF: Dupligráfica, 2002. p. 235-253.

BRANCO, A. M. Ética e legislação. In: CUBAS, Z. S. et al. (Org.). Tratado de animais selvagens medicina veterinária. São Paulo, Roca, 2007. p. 2-14.

BRASIL. Constituição da República Federativa do Brasil. Brasília, DF: Senado Federal, Subsecretaria de Edições Técnicas, 1999.

CARVAJAL, S. R.; SOLANO, F. G. Costa Rica: estado situacional de lugares que funciona como centros de rescate de fauna silvestre. In: DREWS, C. (Ed.). Rescate de fauna em el Neotrópico. Heredia: Euna, 1999. p. 167-201. 
CARVALHO, M. A. S. Relatos de aves silvestres recuperadas e monitoradas em área de soltura. In: PREFEITURA DO MUNICÍPIO DE SÃO PAULO. Secretaria Municipal do Verde e do Meio Ambiente. Fauna silvestre: quem são e onde vivem os animais na metrópole paulistana. São Paulo, 2007. p. 278-281.

CARVALHO, M. A. S.; NAMBA, S. Solturas e Estudos preliminares de monitoramento da avifauna na região metropolitana de São Paulo e outras regiões. In: IBAMA.

Encontro de ASM - Áreas de Soltura e Monitoramento de animais silvestres -

Estado de São Paulo. São Paulo, 2006. p. 15-17. Relatório de Atividades.

CBD - CONVENTION ON BIOLOGICAL DIVERSITY. City of Sao Paulo, Brazil.

Disponível em: <https://www.cbd.int/authorities/casestudy/saopaulo.shtml> . Acesso em: 22 fev. 2008.

CEPAM - CENTRO DE ESTUDOS E PESQUISAS DE ADMINISTRAÇÃO MUNICIPAL - FUNDAÇÃO PREFEITO FARIA LIMA. Pensando a gestão partilhada: a Agenda 21 local. São Paulo, 2001.

CLARK JR, E. E. El papel potencial de la reabilitación en la conservación de vida silvestre en las Américas. In: DREWS, C. (Ed.). Rescate de fauna em el Neotrópico. Heredia: Euna, 1999. p. 89-105.

CORRADO, M. J. Prevalência de anticorpos anti- Leptospira interrogans em répteis silvestres encaminhados ao DEPAVE-3 (São Paulo-SP) no período de janeiro de 1998 a março de 2001. In: CONGRESSO E ENCONTRO DA ASSOCIAÇÃO BRASILEIRA DE ANIMAIS SELVAGENS, 5, 2001, São Paulo. Anais... São Paulo: ABRAVAS, 2001. p. 65.

DALLARI, D. A. Elementos de teoria geral do estado. São Paulo: Saraiva, 2003.

DREWS, C. Simpatía y empatía hacia a la fauna: las raíces de tenencia de mascotas silvestres. In: (Ed.). Rescate de fauna em el Neotrópico. Heredia: Euna, 1999. p. 31-52. 
FOLHA ON LINE. Mais de $50 \%$ dos habitantes do planeta vive em cidades, diz estudo. São Paulo, 2007: Disponível em:

$<$ http://www1.folha.uol.com.br/folha/mundo/ult94u305663.shtml>. Acesso em: 19 jun. 2007.

FORATTINI, O. P. Ecologia, epidemiologia e sociedade. 2. ed. São Paulo: Artes Médicas, 2004.

GIL, A. C. Como elaborar projetos de pesquisa. 4. ed. São Paulo: Atlas, 2002.

GRANDY, J. Rehabilitación y liberación de fauna: um enfoque sencillo. In: DREWS, C. (Ed.). Rescate de fauna em el Neotrópico. Heredia: Euna, 1999. p. 59-64.

GOVERNO DO ESTADO DE SÃO PAULO. Secretaria do Meio Ambiente. Fauna ameaçada no Estado de São Paulo. Documentos ambientais, São Paulo, 1998.

HOYT, J. Poniendo nuestros princípios primero. In: DREWS, C. (Ed.). Rescate de fauna em el Neotrópico. Heredia: Euna, 1999. p. 53-58.

IBAMA - INSTITUTO BRASILEIRO DO MEIO AMBIENTE E DOS RECURSOS NATURAIS RENOVÁVEIS. GEO Brasil 2002: perspectivas do meio ambiente no Brasil. Brasília, DF, 2002.

IBAMA - INSTITUTO BRASILEIRO DO MEIO AMBIENTE E DOS RECURSOS NATURAIS RENOVÁVEIS. Centros de Triagem de Animais Silvestres - CETAS.

Brasília DF, 2007. Disponível em: <http://www.ibama.gov.br/fauna/cetas.php >. Acesso em: 21 jan. 2008.

IBGE - INSTITUTO BRASILEIRO DE GEOGRAFIA E ESTATÍSTICA. Fauna ameaçada de extinção. Rio de Janeiro, 2001. 
IMASUL - INSTITUTO DO MEIO AMBIENTE DO ESTADO DO MATO GROSSO DO SUL . Cras recebeu 1450 animais desde o começo do ano. Mato Grosso do Sul, 2007. Disponível em: <http://www.imasul.ms.gov.br/ler.php?id=772>. Acesso em: 3 jan.2008.

JIMÉNEZ-PÉREZ, I. Los centros de rescate de fauna silvestre como herramientas de conservación. In: DREWS, C. (Ed.). Rescate de fauna em el Neotrópico. Heredia: Euna, 1999. p. 65-88.

LARA, O. F.; LÓPEZ, M.M. Guatemala: estado actual y perspectivas de centros de rescate. In: DREWS, C. (Ed.). Rescate de fauna em el Neotrópico. Heredia: Euna, 1999. p. 225-232.

LEMUS, J. A. A. Cuba: estado actual y perspectiva del rescate de la fauna. In: DREWS, C. (Ed.). Rescate de fauna em el Neotrópico. Heredia: Euna, 1999. p. 215-223.

LEVAY, L. F. Direito dos animais. 2. ed. São Paulo: Mantiqueira, 2004.

LO, V. K. Centro de Triagem de Animais Silvestres. In: UNIÃO PELA FAUNA DA MATA ATLÂNTICA, Seminário ações de combate ao comércio ilegal de animais silvestres na Mata Atlântica. Iguape, 2004. 1 CD-ROM.

LO, V. K. Momento oportuno para aprimorar os trabalhos. In: IBAMA. Encontro de ASM - Áreas de Soltura e Monitoramento de animais silvestres - Estado de São Paulo. São Paulo, 2006. p. 5-7. Relatório de Atividades.

LÓPEZ, A. C. P.; HERRA, N. El Salvador: disposición de animales por el servicio de Parques Nacionales y vida silvestre en 1995. In: DREWS, C. (Ed.). Rescate de fauna em el Neotrópico. Heredia: Euna, 1999. p. 299-309.

MACHADO, P. A. L. Direito ambiental brasileiro. 3. ed. São Paulo: Revista dos Tribunais, 1991. 
MAGALHÃES, A. F. A. Divisão de Fauna Silvestre - SVMA/PMSP. In: UNIÃO PELA FAUNA DA MATA ATLÂNTICA, Seminário ações de combate ao comércio ilegal de animais silvestres na Mata Atlântica. Iguape, 2004. 1 CD-ROM.

MENDOZA, D. R. Panamá: el rescate de fauna silvestre. In: DREWS, C. (Ed.). Rescate de fauna em el Neotrópico. Heredia: Euna, 1999. p. 269-276.

MMA - MINISTÉRIO DO MEIO AMBIENTE. Lista nacional das espécies da fauna ameaçadas de extinção. Brasília, 2007. Disponível em:

<http://www.mma.gov.br/port/sbf/fauna/>. Acesso em: 17 nov. 2007.

MOURA, L. A. A. Qualidade e gestão ambiental. 4. ed. São Paulo: Juarez de Oliveira, 2004.

NOGUEIRA-NETO, P. A criação de animais indígenas vertebrados. São Paulo:

Tecnapis, 1973.

ODUM, E. P. Ecologia. Rio de Janeiro: Guanabara, 1988.

OLIVEIRA, M. A. Tráfico de animais silvestres. Perícia Federal, Brasília, DF, ano II, p. 14-17, jun. 2000.

OJASTI, J. Política de fauna y sus instrumentos. In: DALLMEIER, F. (Ed.). Manejo de fauna silvestre neotropical. Washington, DC.: Smithsonian Institution, 2000. p. 59-72.

PEREDO, C. B. Bolívia: el rescate de fauna comienza a desarrollarse. In: DREWS, C. (Ed.). Rescate de fauna em el Neotrópico. Heredia: Euna, 1999. p. 135-147.

PÉREZ, R. Nicarágua: el comercio de fauna silvestre. In: DREWS, C. (Ed.). Rescate de fauna em el Neotrópico. Heredia: Euna, 1999. p. 243-268.

PHILIPPI JR, A. et al. Agenda 21 local: compromisso do município de São Paulo. São Paulo: Secretaria do Verde e do Meio Ambiente, 1996. 
PMSP - PREFEITURA DO MUNICÍPIO DE SÃO PAULO. Secretaria do Verde e do Meio Ambiente; PNUMA - PROGRAMA DAS NAÇÕES UNIDAS PARA O MEIO AMBIENTE; IPT - INSTITUTO DE PESQUISAS TECNOLÓGICAS DO ESTADO DE SÃO PAULO. GEO cidade de São Paulo: panorama do meio ambiente urbano. São Paulo, 2004.

PMSP - PREFEITURA DA CIDADE DE SÃO PAULO. Secretaria Municipal do Verde e do Meio Ambiente. Preservando a biodiversidade em São Paulo. São Paulo, 2007. Disponível em:

<http://www2.prefeitura.sp.gov.br/secretaria/meio_ambiente/eixo_biodiversidade/0001> Acesso em: 6 out. 2007a.

PMSP - PREFEITURA DA CIDADE DE SÃO PAULO. Secretaria Municipal da Saúde. Vigilância em saúde. Saúde ambiental. São Paulo, 2008. Disponível em:

$<$ http://portal.prefeitura.sp.gov.br/secretarias/saude/vigilancia_saude/ambiental/0001> Acesso em: 17 jun. 2008.

RENCTAS - REDE NACIONAL DE COMBATE AO TRÁFICO DE ANIMAIS SILVESTRES. $1^{\circ}$ Relatório nacional sobre o tráfico de fauna silvestre. Brasília, DF, 2001.

RENCTAS - REDE NACIONAL DE COMBATE AO TRÁFICO DE ANIMAIS

SILVESTRES. Vida silvestre: o estreito limiar entre preservação e destruição. Brasília, DF, 2007.

SANTOS, E. B.; LOPES V. A. Centro de Reabilitação de Animais - CRAS- Resultados de soltura de aves silvestres em fazendas no Mato Grosso do Sul. In: IBAMA. Encontro de ASM - Áreas de Soltura e Monitoramento de animais silvestres - Estado de São Paulo. São Paulo, 2006. p. 11-14. Relatório de Atividades. 
SÃO PAULO (Estado). Secretaria de Estado do Meio Ambiente. Resolução SMA- 8, de 25-4-2000. Diário Oficial do Estado de São Paulo. São Paulo, 26 de abr. 2000, v.110, n.79, p. 35 .

SÃO PAULO (Estado). Lei n ${ }^{\circ} 11.977$, de 25 de agosto de 2005. Institui o código de proteção aos animais do Estado e dá outras providências. Diário Oficial do Estado de São Paulo. São Paulo, 26 ago. 2005. v. 115, n. 162, p. 3-4.

SÃO PAULO (Município). Lei Municipal no 11.426, de 18 de outubro de 1993. Dispõe sobre a criação da Secretaria Municipal do Verde e do Meio Ambiente - SVMA; cria o Conselho Municipal de Meio Ambiente e Desenvolvimento Sustentável - CADES; e dá outras providências. Diário Oficial do Município de São Paulo. São Paulo, 22 out. 1993. v. 38 , n.199, p. $1-5$.

SÃO PAULO (Município). Lei Municipal nº 12.055, de 9 de maio de 1996. Autoriza o Executivo a implantar no Parque Anhanguera, o Centro de Triagem de Animais Silvestres e o Centro de Reabilitação de Animais Silvestres. Diário Oficial do Município de São Paulo. São Paulo, maio 1996. p. 1.

SÃO PAULO (Município). Decreto Municipal no 37.653 de 25 de setembro de 1998. Regulamenta a Lei n ${ }^{\circ} 12.055$, de 9 de maio de 1996, que dispõe sobre a implantação do Centro de Triagem de Animais Silvestres e o Centro de Reabilitação de Animais Silvestres, no Parque Anhanguera, e dá outras providências. Diário Oficial do Município de São Paulo. São Paulo, 26 set. 1998. v. 43, n. 183, p.1.

SÃO PAULO (Município). Secretaria Municipal do Verde e do Meio Ambiente. Inventário da Fauna do Município de São Paulo: resultados preliminares. Diário Oficial do Município de São Paulo. São Paulo, 30 dez. 1998a. v. 43, n. 246, p. 27-35. 
SÃO PAULO (Município). Portaria n ${ }^{\circ}$ 44/SVMA.G/99. Institui o Programa EducaCão nos Parques Municipais. Secretaria Municipal do Verde e do Meio Ambiente. Diário Oficial do Município de São Paulo. São Paulo, 06 ago. 1999. v. 44, n. 147, p. 17.

SÃO PAULO (Município). Secretaria Municipal do Verde e do Meio Ambiente. Inventário da Fauna do Município de São Paulo: resultados preliminares. Diário Oficial do Município de São Paulo. São Paulo, 24 ago. 1999a. v. 44, n. 159, p. 41-56,

SÃO PAULO (Município). Secretaria Municipal do Verde e do Meio Ambiente. Inventário da Fauna do Município de São Paulo: resultados preliminares. Diário Oficial do Município de São Paulo. São Paulo, 21 mar. 2000. v. 45, n. 53, p. 42-60.

SÃO PAULO (Município). Inventário da fauna do Município de São Paulo. Secretaria Municipal do Verde e do Meio Ambiente. Diário Oficial da Cidade de São Paulo Suplemento, São Paulo, 3 Jun. 2006. v. 51, n. 104, p. 1- 47.

SEMAC - SECRETARIA DE ESTADO DO MEIO AMBIENTE, DAS CIDADES, DO PLANEJAMENTO, DA CIÊNCIA E TECNOLOGIA. Organograma da SEMAC,

Mato Grosso do Sul, 2008. Disponível em:

$<$ http://www.semac.ms.gov.br/index.php?inside=1\&tp=3\&comp=3001\&show=1832 >. Acesso em: 3 jan. 2008.

SILVA, J. C. R. et al. Anticorpos anti-Toxoplasma gondii em animais silvestres encaminhados ao DEPAVE-3 (São Paulo-SP) no período de abril de 1995 a março de 1999. In: CONGRESSO E ENCONTRO DA ASSOCIAÇÃO BRASILEIRA DE ANIMAIS SELVAGENS, 2000, São Pedro. Anais.... São Paulo: ABRAVAS, 2000. p. 22.

SILVA, J. C. R. Zoonoses e doenças emergentes transmitidas por animais silvestres. Disponível em: 
$<\mathrm{http}: / /$ www.abravas.com.br/03-zoonoses\%20e\%20Doen\%E7as\%20Emergentes.PDF . Acesso em: 22 de mar. 2008.

SILVA, M. J. et al. Levantamento faunístico dos parques municipais. In: PREFEITURA DO MUNICÍPIO DE SÃO PAULO. Secretaria Municipal do Verde e do Meio Ambiente. A questão ambiental urbana: cidade de São Paulo. São Paulo, 1993, p. 597 613.

SMA - SECRETARIA DE ESTADO DO MEIO AMBIENTE. Seminário sistemas de recepção, manejo e destinação de animais silvestres. Cananéia, 1999. Relatórios Ambientais.

SOBRAL, H. R. O meio ambiente e a cidade de São Paulo. São Paulo: Makron Books, 1996.

SOORAE, P. S.; PRICE, M. R. S. Animales confiscados vivos: Qué opciones hay para su ubicación? In: Manejo y conservación de fauna silvestre em América Latina. La Paz: Instituto de Ecologia, 1999. p. 63-68.

STEINER, R. Honduras: rehabilitación y liberación de aves silvestres em um centro de rescate. In: DREWS, C. (Ed.). Rescate de fauna em el Neotrópico. Heredia: Euna, 1999. p. 233-241.

SUMMA, M. E. L. et al. O bugio Alouatta guariba clamitans (Primates - Atellidae) como indicador da pressão ambiental na Região Metropolitana de São Paulo. In: Resumos do VII Congresso internacional sobre manejo de fauna silvestre, Ilhéus, 2006. 
TAYRA, F; RIBEIRO, H. Modelos de indicadores de sustentabilidade: síntese e avaliação crítica das principais experiências. Saúde e Sociedade, São Paulo, v. 32, n. 1, p. 84-95, 2006.

VASCONCELLOS, S. A. Zoonoses e saúde pública: riscos causados por animais exóticos. Biológico, São Paulo, v. 63, n.1/2, p. 63-65, jan./dez., 2001.

VIO, A. P. A. Centro de Estudos e Manejo de Animais Silvestres. In: UNIÃO PELA FAUNA DA MATA ATLÂNTICA, Seminário ações de combate ao comércio ilegal de animais silvestres na Mata Atlântica. Iguape, 2004. 1 CD-ROM.

WWF-BRASIL. Tráfico de animais silvestres no Brasil: um diagnóstico preliminar. Brasília, DF, 1995.

ZAMBRANO, H.; RODA, J. Colômbia: gestión ambiental y manejo de fauna silvestre decomisada. In: DREWS, C. (Ed.). Rescate de fauna em el Neotrópico. Heredia: Euna, 1999. p. 149-159.

ZELLWEGER, R. Q. Peru: zoocriaderos y el rescate de fauna silvestre. In: DREWS, C. (Ed.). Rescate de fauna em el Neotrópico. Heredia: Euna, 1999. p. 277-283. 
Anexo 1 -Lei Municipal n 12.055, de 9 de maio de 1996, da Cidade de São Paulo, 1996.

\section{Lei Municipal $\mathbf{n}^{0} \mathbf{1 2 . 0 5 5}$, de 9 de Maio de 1996}

Autoriza o Executivo a implantar no Parque Anhanguera, o Centro de Triagem de Animais Silvestres e o Centro de Reabilitação de Animais Silvestres.

(Projeto de Lei $\mathrm{n}^{\circ}$. 716/91, do Vereador Roberto Tripoli).

Paulo Maluf, Prefeito do Município de São Paulo, usando das atribuições que lhe são conferidas por lei.

Faz saber que a Câmara Municipal, em sessão de 10 de abril de 1996, decretou e eu promulgo a seguinte Lei:

Art. $1^{\circ}$ Fica o Executivo autorizado a implantar, no Parque Anhanguera, o Centro de Triagem de Animais Silvestres (CETAS) e o Centro de Reabilitação de Animais Silvestres (CRAS).

Parágrafo único. O CETAS e o CRAS ficam subordinados à Divisão Técnica de Medicina Veterinária e Biologia da Fauna (DEPAVE-3), do Departamento de Parques e Áreas Verdes - DEPAVE, da Secretaria do Verde e do Meio Ambiente - SVMA.

Art. $2^{\circ} \mathrm{O}$ Centro de Triagem de Animais Silvestres (CETAS) será responsável por:

a) receber, através do DEPAVE-3, animais silvestres nativos entregues espontaneamente pela população e/ou apreendidos;

b) elaborar cardápio e ministrar, aos animais mantidos no Centro, alimentos similares aos consumidos em vida livre;

c) efetuar todos os registros no prontuário dos animais mantidos no Centro;

d) orientar e acompanhar os funcionários na captura, contenção e manejo dos animais;

e) orientar e acompanhar os funcionários quanto à correta higienização e desinfecção das instalações, viveiros e recintos dos animais;

f) orientar e acompanhar os trabalhos pertinentes ao biotério;

g) realizar o levantamento bibliográfico das espécies animais atendidas;

h) dar apoio técnico a órgãos públicos e corporações na captura, manejo e apreensão de animais silvestres;

i) dar a adequada destinação aos animais atendidos;

j) promover e apoiar projetos de divulgação e conscientização sobre a Legislação de Proteção à Fauna;

1) promover e apoiar pesquisas na área de proteção ambiental, principalmente as relativas à Fauna Silvestre Nativa; e

m) apresentar ao Diretor de DEPAVE-3 relatórios mensais dos serviços e programas realizados.

Parágrafo único. O CETAS deverá respeitar, na destinação dos animais, as prioridades de: reabilitação, soltura, encaminhamento para entidades devidamente autorizadas.

Art. $3^{\circ} \mathrm{O}$ Centro de Reabilitação de Animais Silvestres (CRAS) será responsável por:

a) receber e prestar assistência aos animais cadastrados no DEPAVE-3 para reabilitação, acompanhando-os até completa recuperação;

b) avaliar o estado biológico dos animais silvestres encaminhados pelo DEPAVE-3, dando-lhes os devidos cuidados e destinação após sua reabilitação; 
c) assistir filhotes, principalmente órfãos, até que os mesmos estejam habilitados a sobreviver em vida livre;

d) realizar o cadastramento e biometria dos animais a serem reabilitados;

e) elaborar cardápio e ministrar, aos animais mantidos no Centro, alimentos similares aos consumidos em vida livre;

f) orientar e acompanhar os funcionários na captura, contenção e manejo dos animais;

g) orientar e acompanhar os funcionários quanto à correta higienização e desinfecção das instalações, viveiros e recintos dos animais;

h) orientar e acompanhar os trabalhos pertinentes ao biotério;

i) treinar os animais recebidos no Centro, visando a recuperação de suas condições anatômicas e fisiológicas, necessárias para a sobrevivência em vida - livre;

j) efetuar todos os registros no prontuário dos animais mantidos no Centro;

1) realizar a soltura e posterior acompanhamento dos animais atendidos no Centro;

m) efetuar a transferência para o CETAS de animais que, submetidos à reabilitação, mantiverem-se inaptos a sobreviver em vida livre;

n) realizar o levantamento bibliográfico das espécies animais atendidas;

o) executar, em conjunto com a Seção Técnica e Assistência Médico-Veterinária Preventiva do DEPAVE-3, os programas desenvolvidos por esta Seção; e

p) apresentar ao Diretor de DEPAVE-3 relatórios mensais dos serviços e programas realizados.

Art. $4^{\circ} \mathrm{O}$ CETAS e o CRAS devem possuir estrutura física adequada e corpo técnico especializado, atendendo a todos os critérios estabelecidos pela Legislação Federal, Estadual e Municipal pertinentes.

Art. $5^{\circ}$ Fica a Secretaria do Verde e do Meio Ambiente - SVMA autorizada a firmar convênios com entidades ambientalistas nacionais e internacionais, de reconhecido conhecimento técnico no assunto, no sentido de desenvolver projetos pertinentes às atividades executadas pelo CETAS e pelo CRAS.

Art. $6^{\circ}$ Fica a Secretaria do Verde e do Meio Ambiente - SVMA autorizada a firmar convênios com empresas privadas, fundações, autarquias e órgãos públicos nacionais e internacionais, no sentido de desenvolver projetos pertinentes às atividades executadas pelo CETAS e pelo CRAS.

Art. $7^{\circ} \mathrm{O}$ Executivo regulamentará esta Lei no prazo de 60 (sessenta) dias, contados a partir da data de sua publicação.

Art. $8^{\circ}$ As despesas decorrentes da execução desta Lei correrão por conta de dotações orçamentárias próprias, suplementadas se necessário.

Art. $9^{\circ}$ Esta Lei entrará em vigor na data de sua publicação, revogadas as disposições em contrário.

(Regulamentada pelo Decreto 37.653/98). 
Anexo 2 - Decreto Municipal n 37.653 de 25 de setembro de 1998, da Lei Municipal ${ }^{\circ}$ 12.055, da Cidade de São Paulo, 1998.

\section{Decreto $n^{0}$ 37.653, de 25 de Setembro de 1998}

Regulamenta a Lei ${ }^{\circ}$ 12.055, de 9 de Maio de 1996, que dispõe sobre a implantação do Centro de Triagem de Animais Silvestres e do Centro de Reabilitação de Animas Silvestres, no Parque Anhanguera, e dá outras providências.

CELSO PITTA, Prefeito do Município de São Paulo, usando das atribuições que lhe são conferidas por lei, DECRETA:

Art. $1^{\circ} \mathrm{O}$ Centro de Triagem de Animais Silvestres - CETAS e o Centro de Reabilitação de Animais Silvestres - CRAS constituem seções técnicas subordinadas à Divisão Técnica de Medicina Veterinária e Biologia da Fauna - DEPAVE-3, do Departamento de Parques e Áreas Verdes - DEPAVE, da Secretaria Municipal do Verde e do Meio Ambiente - SVMA.

Art. $2^{\circ}$ As atividades do CETAS e do CRAS, inclusive as de apoio administrativo, serão desenvolvidas por servidores do DEPAVE.

Art. $3^{\circ} \mathrm{O}$ CETAS e o CRAS terão:

I - Estrutura física adequada e corpo técnico do DEPAVE, atendendo a todos os critérios estabelecidos pela legislação federal, estadual e municipal pertinentes;

II - Estrutura física composta por instalações e equipamentos para a área administrativa, atendimento médico veterinário e biológico, preparação e armazenagem de alimentos, biotério, almoxarifado e recintos para a manutenção e reabilitação de animais silvestres (mamíferos, aves, répteis, anfíbios e peixes).

Art. $4^{\circ}$ Ao Centro de Triagem de Animais Silvestres - CETAS caberá:

I - Receber, por intermédio do DEPAVE-3, animais silvestres nativos entregues espontaneamente pela população e/ou apreendidos;

II - Elaborar cardápio e ministrar aos animais nele mantidos alimentos similares aos consumidos em vida livre;

III - Efetuar todos os registros no prontuário dos animais nele mantidos;

IV - Orientar e acompanhar os funcionários na captura, contenção e manejo dos animais;

V - Orientar e acompanhar os funcionários quanto à correta higienização e desinfecção das instalações, viveiros e recintos dos animais;

VI - Orientar e acompanhar os trabalhos pertinentes ao biotério;

VII - Realizar o levantamento bibliográfico das espécies animais atendidas;

VIII - Dar apoio técnico a órgãos públicos e corporações, na captura, manejo e apreensão de animais silvestres;

IX - Dar a adequada destinação aos animais atendidos;

X - Promover e apoiar projetos de divulgação e conscientização sobre a legislação de proteção à fauna;

XI - Promover e apoiar pesquisas na área de proteção ambiental, principalmente as relativas à fauna silvestre nativa;

XII - Apresentar ao Diretor do DEPAVE-3 relatórios mensais dos serviços e programas realizados. 
Parágrafo único. O CETAS deverá respeitar, na destinação dos animais, as prioridades de reabilitação, soltura e encaminhamento para entidades devidamente autorizadas.

Art. $5^{\circ}$ Ao Centro de Reabilitação de Animais Silvestres - CRAS caberá:

I - Receber e prestar assistência aos animais cadastrados no DEPAVE-3 para reabilitação, acompanhando-os até completa recuperação;

II - Avaliar o estado biológico dos animais silvestres encaminhados pelo DEPAVE-3, dando-lhes os devidos cuidados e destinação após sua reabilitação;

III - Assistir filhotes, principalmente órfãos, até que estejam habilitados a sobreviver em vida livre;

IV - Realizar o cadastramento e biometria dos animais a serem reabilitados;

V - Elaborar cardápio e ministrar, aos animais nele mantidos, alimentos similares aos consumidos em vida livre;

VI - Orientar e acompanhar os funcionários na captura, contenção e manejo dos animais; VII - Orientar e acompanhar os funcionários quanto à correta higienização e desinfecção das instalações, viveiros e recintos dos animais;

VIII - Orientar e acompanhar os trabalhos pertinentes ao biotério;

IX - Treinar os animais nele recebidos, visando a recuperação de suas condições anatômicas e fisiológicas, necessárias para a sobrevivência em vida livre;

$\mathrm{X}$ - Efetuar todos os registros no prontuário dos animais nele mantidos;

XI - Realizar a soltura e posterior acompanhamento dos animais nele atendidos;

XII - Efetuar a transferência para o CETAS de animais que, submetidos à reabilitação, mantiverem-se inaptos a sobreviver em vida livre;

XIII - Realizar o levantamento bibliográfico das espécies animais atendidas;

XIV - Executar, em conjunto com a Seção Técnica de Medicina Veterinária Preventiva do DEPAVE-3, os programas desenvolvidos por essa Seção;

XV - Apresentar ao Diretor do DEPAVE-3 relatórios mensais dos serviços e programas realizados.

Art. $6^{\circ} \mathrm{O}$ CETAS e o CRAS funcionarão em período mínimo de 10 (dez) horas diárias, inclusive aos sábados, domingos e feriados.

Art. $7^{\circ} \mathrm{O}$ cadastramento dos animais recebidos pelo DEPAVE-3 deverá ser realizado em documento próprio de retenção de espécime, contendo informações de entrada quanto à identificação taxonômica, local de procedência e histórico, bem como informações quanto à destinação dada.

Parágrafo único. A origem do animal deverá estar registrada no documento de retenção, em campo apropriado, que possibilite a sua comprovação.

Art. $8^{\circ} \mathrm{O}$ prontuário dos animais deverá estar devidamente arquivado e ser composto pelo documento de retenção, fichas clínicas, fichas biológicas, laudos de exames complementares e, no caso de óbito, do laudo de necropsia.

Art. $9^{\circ}$ Para as espécies ameaçadas de extinção, deverão ser atendidas as determinações e normas legais vigentes.

Art. 10. A soltura de animais da fauna local somente poderá ser realizada mediante avaliação técnica e respeitadas as informações mínimas quanto à procedência e ao estado de saúde do animal e a comprovação da ocorrência da espécie na área de soltura.

Art. 11. Os procedimentos técnicos e administrativos relativos à fauna deverão atender às normas vigentes e exigências do órgão federal competente. 
Art. 12. Respeitada a legislação vigente, a Secretaria Municipal do Verde e do Meio Ambiente - SVMA fica autorizada a firmar convênios com entidades ambientalistas nacionais e internacionais, de reconhecido conhecimento técnico no assunto, e com empresas privadas, fundações, autarquias e órgãos públicos nacionais e internacionais, no sentido de desenvolver projetos pertinentes às atividades executadas pelo CETAS e pelo CRAS.

Art. 13. As despesas decorrentes da execução deste decreto correrão por conta das dotações orçamentárias próprias, suplementadas se necessário.

Art. 14. Este decreto entrará em vigor na data de sua publicação, revogadas as disposições em contrário.

Data de Publicação: 26/09/1998 
Anexo 3 - Portaria n 008/DEPAVE-G/92, de 14 de abril de 1992.

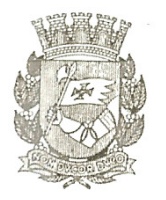

Prefeitura do Município de São Paulo DEPARTAMENTO DE PARQUES E ÁREAS VERDES

$$
\text { São Paulo, }{ }^{14} \text { de abril de } 1992
$$

Portaria n. ${ }^{\circ}$ 008/Depave-G/92

$$
\begin{aligned}
& \text { PUELICADO } \\
& 24,04192 \\
& \text { LGI OYR } \\
& \text { DEPAVE- } 6
\end{aligned}
$$

O DIRETOR DO DEPARTAMENTO DE PARQUES E AREAS VERDES, no uso das atribuições que the são conferidas por lei,

CONSIDERANDO a grande deversidade de espécies animais que são encontradas nos Parques Municipais, e o interesse deste Departamento de Parques e Áreas Ver des na prestação de uma assistência médica veterinária à essas espécies, as sim como no seu manejo adequado,

\section{RES O L V E:}

1. Designar a médica-veterinária Angela Maria Branco Espuny a a Bióloga Teresa de Lourdes Cavalheiro, para implantarem, coordenarem e executarem junto ao DEPAVE-5, o projeto referente a "criação do serviço médico-veterinário, biologia e de manejo de fauna no DEPAVE".

2. Está Portaria entrará em vigor na data de sua pubícaçào.

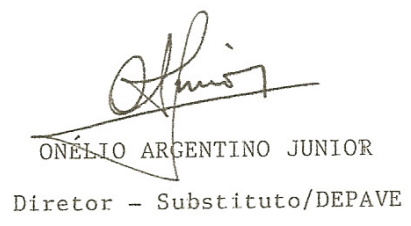

Original: $A \cdot M \cdot B \cdot E$.

Cópias : T.L.C.

DEPAVE-G

DEPAVE-5 


\title{
Anexo 4 - Carta do PhD Chris Wermer, de 05 de dezembro de 1988 , ao Prefeito Jânio Prefeito Jânio da Silva Quadros.
}

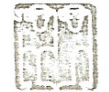 \\ Fundação Parque Zoológico de São Paulo
}

Chris Wermer, Ph. D.

Assistant Director for Conservation and Captive Breeding

Conservation and Research Center

National Zoological Park

Front Royal, Virginia 22630

U. S. I.

São Paulo, December 5th, 1988

Janio da Silva Quadros

Gabinete do Prefeito

Parque Ibirapuera

são Paulo, Brasil

Dear Mr. Mayor:

I recently had the opportunity to experience scme of the excellent municipal parks in São Paulo. During the presentation of a training program on zoo animal management at the São Paulo Zoo I learned more about the efforts to improve the management and care of the many wild animals that live in the parks of this fine city. As a professional zoologist I can honestly state that it is nothing short of a miracle that sloths, wild cats, deer and armadillos survive in a city of 17 million people: I was also surprised to learn that a veterinarian has been given responsibility for the care and treatment of the animals which are enjoyed by the citizens of this great city.

Dr. Angela Espuny, municipal parks veterinarian, has developed a plan to manage and care for the wildlife in the city's parks. Because domestic animals carry many diseases, wildlife in city parks can be seriously threatened by epidemic transmitted by pets. Consequently, trained veterinarians and biologists should manage urban wildlife to insure its continued survival. The program proposed by Dr. Espuny will therefore serve an important purpose. However, to be successful, this program will require a commitment of personnel, biologists and veterinarians, who can dedicate themselves to monitoring the size, nutrition, and health status of the populations. I strongly urge you to support the program by allocating funds for the support of staff, equipment and supplies. Unfortunately, few people understand or appreciate the irmoortance of wildilife management. Knowing your own interest and concern for wildlife however, I am hopeful that the proper measures can be taken to improve this city's ability to safeguard this valuable resource.

With kind regards,

Sincerely,

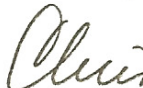

Plemmace

Chris Wermer, Ph. D.

Assistant Director for Conservation

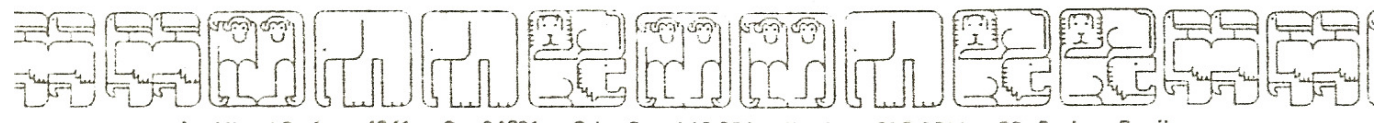

Av. Miguel Stefano, 4241 - Cep 04301 - Caixa Postal 12.954 - Telefone: 276-0811 - São Paulo - Brasil 
Anexo 5 - Relação das espécies de animais vertebrados levantada no inventário da fauna da Cidade de São Paulo (SÃO PAULO, 2006).

\section{CLASSE OSTEICHTHYES}

\begin{tabular}{|c|l|l|c|}
\hline $\mathbf{N}^{\mathbf{2}}$ & NOME POPULAR & NOME CIENTÍFICO & AMEAÇA $^{\mathbf{4 6}}$ \\
\hline 01 & Carpa-comum & Cyprinus carpio & - \\
\hline 02 & Curimbatá & Prochilodus lineatus & - \\
\hline 03 & Sarapó & Gymnotus carapo & - \\
\hline 04 & Suribin & Pseudoplatystoma fasciatum & - \\
\hline 05 & Bagre Africano & Clarias gariepinus & - \\
\hline 06 & Guarú & Phalloceros caudimaculatus & - \\
\hline 07 & Lebiste & Poecilia reticulata & - \\
\hline 08 & Acará & Geophagus brasiliensis & - \\
\hline 09 & Tilápia-do-Nilo & Oreochromis niloticus & - \\
\hline
\end{tabular}

\section{CLASSE AMPHIBIA}

\begin{tabular}{|c|l|l|c|}
\hline $\mathbf{N}^{\mathbf{0}}$ & NOME POPULAR & NOME CIENTÍFICO & AMEAÇA \\
\hline 01 & Rã-da-mata & Eleutherodactylus binotatus & - \\
\hline 02 & Rã-da-mata & Eleutherodactylus guentheri & - \\
\hline 03 & Rãzinha-do-chão-da-mata & Eleutherodactylus parvus & - \\
\hline 04 & Rãzinha-do-chão-da-mata & Eleutherodactylus cf. spanios & - \\
\hline 05 & Sapa-cururu & Chaunus ictericus & - \\
\hline 06 & Sapo & Chaunus ornatus & - \\
\hline
\end{tabular}

\footnotetext{
${ }^{46}$ Grau de ameaça de extinção, de acordo com o Decreto Estadual no 42.838/98 - Lista da Fauna Silvestre Ameaçada de Extinção e Provavelmente Ameaçada de Extinção no Estado de São Paulo.

Anexo I-EP: espécie ameaçada de extinção na categoria Em Perigo (risco de extinção no futuro próximo) Anexo I-VU: espécie ameaçada de extinção na categoria Vulnerável (alto risco de extinção a médio prazo) Anexo I-CP: espécie ameaçada de extinção na categoria Criticamente em Perigo (alto risco de extinção em futuro muito próximo)

Anexo II: espécie provavelmente ameaçada de extinção
} 


\begin{tabular}{|c|c|c|c|}
\hline 07 & $\begin{array}{l}\text { Sapinho-arborícola-de-polegar- } \\
\text { curto }\end{array}$ & $\begin{array}{l}\text { Dendrophryniscus } \\
\text { brevipollicatus }\end{array}$ & - \\
\hline 08 & Sapinho-arborícola & $\begin{array}{l}\text { Dendrophryniscus cf. } \\
\text { leucomystax }\end{array}$ & - \\
\hline 09 & Rã-de-vidro & $\begin{array}{l}\text { Hyalinobatrachium } \\
\text { uranoscopum }\end{array}$ & Anexo II \\
\hline 10 & Perereca-flautinha & Aplastodiscus albosignatus & - \\
\hline 11 & Perereca-verde & Aplastodiscus leucopygius & - \\
\hline 12 & Perereca & Bokermannohyla astartea & - \\
\hline 13 & Perereca-com-anéis-nas-coxas & Bokermannohyla circumdata & - \\
\hline 14 & Perereca & Bokermannohyla hylax & - \\
\hline 15 & Pererequinha & Dendropsophus berthalutsae & - \\
\hline 16 & Perereca & Dendropsophus microps & - \\
\hline 17 & Perereca & Dendropsophus minutus & - \\
\hline 18 & Perereca-verde-de-coxas-laranjas & Hypsiboas albomarginatus & - \\
\hline 19 & Perereca-trepadora-punctada & Hypsiboas albopunctatus & - \\
\hline 20 & Perereca-lineada & Hypsiboas bischoffi & - \\
\hline 21 & Sapo-ferreiro & Hypsiboas faber & - \\
\hline 22 & Perereca & Hypsiboas cf. polytaenius & - \\
\hline 23 & Perereca & Hypsiboas prasinus & - \\
\hline 24 & Perereca & Scinax crospedospilus & - \\
\hline 25 & Perereca-de-banheiro & Scinax fuscovarius & - \\
\hline 26 & Perereca-de-banheiro & Scinax hayii & - \\
\hline 27 & Perereca-de-bromélia & Scinax perpusillus & - \\
\hline 28 & Perereca & Scinax sp. (gr. catharinae) & - \\
\hline 29 & Perereca & Scinax sp. (aff.duartei) & - \\
\hline 30 & Perereca & Sphaenorhynchus cf. orophylus & - \\
\hline 31 & Perereca-de-folhagem & Phasmahyla cochranae & - \\
\hline 32 & Perereca-de-folhagem & Phyllomedusa burmeisteri & - \\
\hline
\end{tabular}




\begin{tabular}{|c|l|l|c|}
\hline 33 & Perereca-de-folhagem & Phyllomedusa cf. tetraploidea & - \\
\hline 34 & Rã-assoviadora & Leptodactylus fuscus & - \\
\hline 35 & Rãzinha-piadeira & Leptodactylus marmoratus & - \\
\hline 36 & Rã-manteiga & Leptodactylus ocellatus & - \\
\hline 37 & Rãzinha & Paratelmatobius cardosoi & - \\
\hline 38 & Rã-cachorro & Physalaemus cuvieri & - \\
\hline 39 & Rã-gemedeira & Physalaemus olfersii & - \\
\hline 40 & Rã & Rana catesbeiana & - \\
\hline
\end{tabular}

\section{CLASSE REPTILIA}

\begin{tabular}{|c|l|l|c|}
\hline $\mathbf{N}^{\mathbf{0}}$ & NOME POPULAR & NOME CIENTÍFICO & AMEAÇA \\
\hline 01 & Cágado-pescoço-de-cobra & Hydromedusa tectifera & Anexo II \\
\hline 02 & Cágado-de-barbicha & Phrynops geoffroanus & - \\
\hline 03 & Tigre-d'água & Trachemys dorbigni & - \\
\hline 04 & Tigre-d'água-de-orelha-vermelha & Trachemys scripta elegans & - \\
\hline 05 & Jacaré-do-pantanal & Caiman crocodilus & - \\
\hline 06 & Jacaré-de-papo-amarelo & Caiman latirostris & AnexoI-VU \\
\hline 07 & Lagartixa-de-parede & Hemidactylus mabouia & - \\
\hline 08 & Papa-vento & Enyalius inheringii & - \\
\hline 09 & Camaleão & Enyalius perditus & Anexo II \\
\hline 10 & Iguana & Iguana iguana & - \\
\hline 11 & Taraguira & Tropidurus torquatus & - \\
\hline 12 & Lagarto-ameiva & Ameiva ameiva & - \\
\hline 13 & Lagarto-teiú & Tupinambis merianae & - \\
\hline 14 & Cobra-de-vidro & Ophiodes fragilis & - \\
\hline 15 & Cobra-de-duas-cabeças & Amphisbaena alba & - \\
\hline 16 & Falsa-coral & Apostolepis assimillis & Atractus pantostictus \\
\hline 17 & Cobra-da-terra & & - \\
\hline
\end{tabular}




\begin{tabular}{|c|l|l|c|}
\hline 18 & Cobra-cipó & Chironius bicarinatus & - \\
\hline 19 & - & Echinanthera affinis & - \\
\hline 20 & Papa-rã & Echinanthera undulata & - \\
\hline 21 & Falsa-coral & $\begin{array}{l}\text { Erythrolamprus aesculapii } \\
\text { venustissimus }\end{array}$ & - \\
\hline 22 & Cobra-d'água & Helicops modestus & - \\
\hline 23 & Cobra-verde & Liophis jaegeri & - \\
\hline 24 & Cobra-d'água & Liophis miliaris & - \\
\hline 25 & Cobra-verde & Liophis typhlus & - \\
\hline 26 & Falsa-coral & Oxyrhopus clathratus & - \\
\hline 27 & Falsa-coral & Oxyrhopus guibei & - \\
\hline 28 & Cobra-verde & Philodryas olfersii & - \\
\hline 29 & Parelheira & Philodryas patagoniensis & - \\
\hline 30 & Dormideira & Sibynomorphus mikanii & - \\
\hline 31 & Dormideira & Sibynomorphus neuwiedi & - \\
\hline 32 & Corredeira & Thamnodynastes strigatus & - \\
\hline 33 & Cobra-espada & Tomodon dorsatus & - \\
\hline 34 & Cobra-cipó & Tropidodryas striaticeps & Waglerophis merremii \\
\hline 35 & Boipeva & Bothrops jararaca & - \\
\hline 36 & Jararaca & Crotalus durissus terrificus & - \\
\hline 37 & Cascavel & & - \\
\hline
\end{tabular}

\section{CLASSE AVES}

\begin{tabular}{|c|l|l|c|}
\hline $\mathbf{N}^{\mathbf{0}}$ & NOME POPULAR & NOME CIENTÍFICO & AMEAÇA \\
\hline 01 & Inhambu-guaçu & Crypturellus obsoletus & - \\
\hline 02 & Inhambu-chintã & Crypturellus tataupa & - \\
\hline 03 & Macuco & Tinamus solitarius & Anexo I-VU \\
\hline 04 & Mergulhão-grande & Policephorus major & - \\
\hline
\end{tabular}




\begin{tabular}{|c|c|c|c|}
\hline 05 & Mergulhão & Podylimbus podiceps & - \\
\hline 06 & Mergulhão-de-cara-branca & Rollandia rolland & - \\
\hline 07 & Mergulhão-pequeno & Tachybaptus dominicus & - \\
\hline 08 & Biguá & Phalacrocorax brasilianus & - \\
\hline 09 & Biguatinga & Anhinga anhinga & - \\
\hline 10 & Garça-branca-grande & Ardea alba & - \\
\hline 11 & Socó-grande & Ardea cocoi & - \\
\hline 12 & Garça-vaqueira & Babulcus íbis & - \\
\hline 13 & Socozinho & Butorides striata & - \\
\hline 14 & Garça-branca-pequena & Egretta thula & - \\
\hline 15 & Socó-amarelo & Ixobrychus involucris & - \\
\hline 16 & Savacu & Nycticorax nycticorax & - \\
\hline 17 & Maria-faceira & Syrigma sibilatrix & - \\
\hline 18 & Socó-boi & Tigrisoma lineatum & - \\
\hline 19 & Cabeça-seca & Mycteria americana & Anexo I-VU \\
\hline 20 & Colhereiro & Platalea ajaja & - \\
\hline 21 & Curicaca & Theristicus caudatus & - \\
\hline 22 & Urubu-de-cabeça-preta & Coragyps atratus & - \\
\hline 23 & Ananaí & Amazonetta brasiliensis & - \\
\hline 24 & Marreca-parda & Anas georgica & - \\
\hline 25 & Asa-branca & Dendrocygna autumnalis & - \\
\hline 26 & Marreca-caneleira & Dendrocygna bicolor & - \\
\hline 27 & Irerê & Dendrocygna viduata & - \\
\hline 28 & Pato-de-crista & Sarkidiornis melanotos & - \\
\hline 29 & Águia-pescadora & Pandion haliaetus & Anexo II \\
\hline 30 & Gavião-miúdo & Accipiter striatus & - \\
\hline 31 & Gavião-de-rabo-branco & Buteo albicaudatus & - \\
\hline 32 & Gavião-de-cauda-curta & Buteo brachyurus & - \\
\hline 33 & Gavião-caboclo & Buteogallus meridionalis & - \\
\hline
\end{tabular}




\begin{tabular}{|c|c|c|c|}
\hline 34 & Peneira & Elanus leucurus & - \\
\hline 35 & Gavião-bombachinha & Harpagus diodon & - \\
\hline 36 & Gavião-pomba & Leucopternes lacernulatus & Anexo I-VU \\
\hline 37 & Gavião-de-cabeça-cinza & Leptodon cayanensis & Anexo II \\
\hline 38 & Gavião-asa-de-telha & Parabuteo unicinctus & Anexo I-EP \\
\hline 39 & Gavião-caramujeiro & Rosthramus sociabilis & - \\
\hline 40 & Gavião-carijó & Rupornis magnirostris & - \\
\hline 41 & Gavião-pega-macaco & Spizaetus tyrannus & Anexo I-VU \\
\hline 42 & Caracará & Caracara plancus & - \\
\hline 43 & Falcão-de-coleira & Falco femoralis & - \\
\hline 44 & Falcão-peregrino & Falco peregrinus & - \\
\hline 45 & Quiriquiri & Falco sparverius & - \\
\hline 46 & Acauã & Herpetotheres cachinanns & - \\
\hline 47 & Gavião-relógio & Micrastur semitorquatus & - \\
\hline 48 & Carrapateiro & Milvago chimachima & - \\
\hline 49 & Jacuguaçu & Penélope obscura & Anexo II \\
\hline 50 & Uru & Odontophorus capueira & - \\
\hline 51 & Carão & Aramus guarauna & - \\
\hline 52 & Saracurinha-da-mata & Amaurolimnas concolor & - \\
\hline 53 & Três-potes & Aramides cajanea & - \\
\hline 54 & Saracura-do-mato & Aramides saracura & - \\
\hline 55 & Frango-d'água-comum & Gallinula chloropus & - \\
\hline 56 & Saracura-carijó & Pardirallus maculatus & - \\
\hline 57 & Saracura-sanã & Pardirallus nigricans & - \\
\hline 58 & Frango-d'água-azul & Porphyrio martinica & - \\
\hline 59 & Picaparra & Heliornis fulica & Anexo I-VU \\
\hline 60 & Jaçanã & Jacana jacana & - \\
\hline 61 & Quero-quero & Vanellus chilensis & - \\
\hline 62 & Pernilongo-de-costas-brancas & Himantopus melanurus & - \\
\hline
\end{tabular}




\begin{tabular}{|c|c|c|c|}
\hline 63 & Corta-d'água & Rynchops niger & - \\
\hline 64 & Pombo-doméstico & Columba lívia domestica & - \\
\hline 65 & Rolinha & Columbina talpacoti & - \\
\hline 66 & Juriti-piranga & Geotrygon montana & - \\
\hline 67 & Juriti-vermelha & Geotrygon violácea & Anexo I-VU \\
\hline 68 & Gemedeira & Leptotila rufaxilla & - \\
\hline 69 & Juriti & Leptotila verreauxi & - \\
\hline 70 & Pomba-galega & Patagioenas cayennensis & - \\
\hline 71 & Asa-branca & Petagioenas picazuro & - \\
\hline 72 & Pomba-amargosa & Petagioenas pumblea & - \\
\hline 73 & Pomba-trocal & Petagioenas speciosa & - \\
\hline 74 & Avoante & Zenaida auriculata & - \\
\hline 75 & Papagaio-verdadeiro & Amazona aestiva & Anexo I-VU \\
\hline 76 & Jandaia-da-testa-vermelha & Aratinga auricapillus & Anexo I-VU \\
\hline 77 & Periquitão-maracanã & Aratinga leucophthalma & - \\
\hline 78 & Periquito-de-encontro-amarelo & Brotogeris chiriri & - \\
\hline 79 & Periquito-rico & Brotogeris tirica & - \\
\hline 80 & Maracanã-nobre & Diopsittaca nobilis & Anexo I-EP \\
\hline 81 & Tuim & Forpus xanthopterygius & - \\
\hline 82 & Caturrita & Myiopsitta monachus & - \\
\hline 83 & Cuiú-cuiú & Pionopsitta pileata & Anexo I-VU \\
\hline 84 & Maitaca-de-maximiliano & Pionus maximiliani & - \\
\hline 85 & Tiriba-de-testa-vermelha & Pyrrhura frontalis & - \\
\hline 86 & Papa-lagarta-de-Euler & Coccyzus euleri & - \\
\hline 87 & Papa-lagarta & Coccyzus melacoryphus & - \\
\hline 88 & Anu-preto & Crotophaga ani & - \\
\hline 89 & Anu-branco & Guira guira & - \\
\hline 90 & Alma-de-gato & Piaya cayana & - \\
\hline 91 & Saci & Tapera naevia & - \\
\hline
\end{tabular}




\begin{tabular}{|c|c|c|c|}
\hline 92 & Suindara & Tyto alba & - \\
\hline 93 & Mocho-diabo & Asio stygius & Anexo I-VU \\
\hline 94 & Buraqueira & Athene cunicularia & - \\
\hline 95 & Mocho-orelhudo & Bubo virginianus & - \\
\hline 96 & Corujinha-do-mato & Megascops choliba & - \\
\hline 97 & Morucututu-de-barriga-amarela & Pulsatrix koeniswaldiana & - \\
\hline 98 & Coruja-orelhuda & Rhynoptynx clamator & - \\
\hline 99 & Urutau & Nyctibius griséus & - \\
\hline 100 & Bacurau-pequeno & Caprimulgus parvulus & - \\
\hline 101 & Tuju & Lurocalis semitorquatus & - \\
\hline 102 & Curiango & Nyctidromus albicollis & - \\
\hline 103 & Androrinhão-do-temporal & Chaetura meridionalis & - \\
\hline 104 & Andorinhão-de-coleira & Streptoprocne zonaris & - \\
\hline 105 & Beija-flor-de-garganta-verde & Amazilia fimbriata & - \\
\hline 106 & Beija-flor-de-peito-azul & Amazilia lactea & - \\
\hline 107 & Beija-flor-de-banda-branca & Amazilia versicolor & - \\
\hline 108 & Beija-flor-preto & Anthracothorax nigricolis & - \\
\hline 109 & Estrelinha & Calliphlox amethystina & - \\
\hline 110 & Besourinho-de-bico-vermelho & Chlorostilbon aureoventris & - \\
\hline 111 & Beija-flor-de-orelha-violeta & Colibri serrirostris & - \\
\hline 112 & Tesourão & Eupetomena macroura & - \\
\hline 113 & Beija-flor-dourado & Hylocharis chrysura & - \\
\hline 114 & Beija-flor-roxo & Hylocharis cyanus & - \\
\hline 115 & Papo-branco & Leucochloris albicollis & - \\
\hline 116 & Beija-flor-preto-e-branco & Florisuga fusca & - \\
\hline 117 & Rabo-branco-de-sobre-amarelo & Phaetornis pretrei & - \\
\hline 118 & Tesoura-de-fronte-violeta & Thalurania glaucopis & - \\
\hline 119 & Surucuá-de-peito-azul & Trogon surrucura & - \\
\hline 120 & Arirambinha & Chloroceryle aenea & Anexo II \\
\hline
\end{tabular}




\begin{tabular}{|c|c|c|c|}
\hline 121 & Martim-pescador-verde & Chloroceryle amazona & - \\
\hline 122 & Martim-pescador-pequeno & Chloroceryle americana & - \\
\hline 123 & Martim-pescador-grande & Ceryle torquatus & - \\
\hline 124 & João-barbudo & Malacoptila striata & - \\
\hline 125 & João-bobo & Nystalus chacuru & - \\
\hline 126 & Tucano-de-bico-verde & Ramphastos dicolorus & - \\
\hline 127 & Tucano-de-bico-preto & Ramphastos vitellinus & - \\
\hline 128 & Araçari-poca & Selenidera maculirostris & - \\
\hline 129 & Pica-pau-de-cabeça-amarela & Celeus flavescens & - \\
\hline 130 & Pica-pau-do-campo & Colaptes campestris & - \\
\hline 131 & Pica-pau-verde-barrado & Colaptes melanochloros & - \\
\hline 132 & Pica-pau-de-banda-branca & Dryocopus lineatus & - \\
\hline 133 & Birro & Melanerpes candidus & - \\
\hline 134 & Pica-pau-anão-barrado & Picumnus temminckii & - \\
\hline 135 & Pica-pauzinho-verde-carijó & Veniliornis spilogaster & - \\
\hline 136 & Matracão & Batara cinerea & - \\
\hline 137 & Papo-branco & Biatas nigropectus & Anexo I-CP \\
\hline 138 & Choquinha-carijó & Drymophila malura & - \\
\hline 139 & Choquinha-lisa & Dysithamnus mentalis & - \\
\hline 140 & Borralhara-assobiadora & Machenziaena leachii & - \\
\hline 141 & Papa-formiga-da-grota & Myrmeciza squamosa & - \\
\hline 142 & Choquinha-da-garganta-pintada & Myrmecisa gularis & - \\
\hline 143 & Papa-taoca-do-sul & Pyriglena leucoptera & - \\
\hline 144 & Choca-da-mata & Thamnophilus caerulescens & - \\
\hline 145 & Choca-de-chapéu-vermelho & Thamnophilus ruficapillus & - \\
\hline 146 & Chupa-dente & Conopophaga lineata & - \\
\hline 147 & Barraqueiro-de-olho-branco & Automolus leucophtalmus & - \\
\hline 148 & Curitié & Certhiaxis cinnamomeus & - \\
\hline 149 & Arredio-pálido & Granioleuca pallida & - \\
\hline
\end{tabular}




\begin{tabular}{|c|c|c|c|}
\hline 150 & João-de-barro & Furnarius rufus & - \\
\hline 151 & João-porca & Lochmias nematura & - \\
\hline 152 & Limpa-folha-testa-baia & Philydor rufum & - \\
\hline 153 & Vira-folhas & Sclerurus scansor & - \\
\hline 154 & Pichororé & Synallaxis ruficapilla & - \\
\hline 155 & João-teneném & Synallaxis spixi & - \\
\hline 156 & Bico-virado-carijó & Xenops rutilans & - \\
\hline 157 & Arapaçu-do-cerrado & Lepidocolaptes angustirostris & - \\
\hline 158 & Arapaçu-escamado & Lepidocolaptes squammatus & - \\
\hline 159 & Arapaçu-verde & Sittasomus griseicapillus & - \\
\hline 160 & Arapaçu-rajado & Xyphorhynchus fuscus & - \\
\hline 161 & Lavadeira-de-cabeça-branca & Arundinicola leucocephala & - \\
\hline 162 & Capitão-de-saíra & Attila rufus & - \\
\hline 163 & Risadinha & Comptostoma obsoletum & - \\
\hline 164 & Viuvinha & Colonia colonus & - \\
\hline 165 & Bentevi-pequeno & Conopias trivirgatus & - \\
\hline 166 & Papa-mosca-cinzento & Contopus cinereus & - \\
\hline 167 & Guaracava-de-barriga-amarela & Elaenia flavogaster & - \\
\hline 168 & Tuque & Elaenia mesoleuca & - \\
\hline 169 & Tucão & Elaenia obscura & - \\
\hline 170 & Peitica & Empidonomus varius & - \\
\hline 171 & Lavadeira-mascarada & Fluvicola nengeta & - \\
\hline 172 & Tiririzinho-do-mato & Hemitriccus orbitatus & - \\
\hline 173 & Gibão-de-couro & Hirundinea ferruginea & - \\
\hline 174 & Enferrujado & Lathrotriccus euleri & - \\
\hline 175 & Bentevi-pirata & Legatus leucophaius & - \\
\hline 176 & Cabeçudo & Leptopogon amaurocephalus & - \\
\hline 177 & Bentevi-do-gado & Machetornis rixosa & - \\
\hline 178 & Bentevi-do-bico-chato & Megarynchus pitangua & - \\
\hline
\end{tabular}




\begin{tabular}{|c|c|c|c|}
\hline 179 & Abre-casa-de-cabeça-cinza & Mionectes rufiventris & - \\
\hline 180 & Tesoura-cinzenta & Muscipipra vetula & - \\
\hline 181 & Maria-cavaleira & Myiarchus ferox & - \\
\hline 182 & Irrê & Myiarchus swainsoni & - \\
\hline 183 & Assanhadinho & Myiobius barbatus & - \\
\hline 184 & Bentevi-rajado & Myiodynastes maculatus & - \\
\hline 185 & Filipe & Myiophobus fasciatus & _- \\
\hline 186 & Miudinho & Myiornis auricularis & - \\
\hline 187 & $\begin{array}{l}\text { Bentevizinho-penacho- } \\
\text { vermelho }\end{array}$ & Myiozetetes similis & - \\
\hline 188 & Caneleiro & Pachyramphus castaneus & - \\
\hline 189 & Caneleiro-preto & Pachyramphus polychopterus & - \\
\hline 190 & Caneleiro-de-chapéu-negro & Pachyramphus validus & - \\
\hline 191 & Piolhinho & Phyllomias fasciatus & - \\
\hline 192 & Bentevi & Pitangus sulphuratus & - \\
\hline 193 & Patinho & Platyrinchus mystaceus & _- \\
\hline 194 & Ferreirinho-de-cara-canela & Poecilotriccus plumbeiceps & - \\
\hline 195 & Verão & Pyrocephalus rubinus & - \\
\hline 196 & Suiriri-pequeno & Satrapa icterophrys & - \\
\hline 197 & Alegrinho & Serpophaga subcristata & - \\
\hline 198 & Gritador & Sirystes sibilator & - \\
\hline 199 & Anambé-branco-de-rabo-preto & Tityra cayana & - \\
\hline 200 & Relógio & Todirostrum cinereum & - \\
\hline 201 & Teque-teque & Todirostrum poliocephalum & - \\
\hline 202 & Bico-chato-de-orelha-preta & Tolmomyias sulphurescens & - \\
\hline 203 & Suiriri & Tyrannus melancholicus & - \\
\hline 204 & Tesoura & Tyrannus savana & - \\
\hline 205 & Maria-branca & Xolmis cinereus & - \\
\hline 206 & Tangará & Chiroxiphia caudata & - \\
\hline
\end{tabular}




\begin{tabular}{|c|c|c|c|}
\hline 207 & Fautim & Schiffornis virescens & - \\
\hline 208 & Corocochó & Carpornis cucullata & - \\
\hline 209 & Chibante & Laniisoma elegans & Anexo I-CP \\
\hline 210 & Araponga & Procnias nudicollis & Anexo I-VU \\
\hline 211 & Pavão-do-mato & Pyroderus scutatus & Anexo I-EP \\
\hline 212 & Andorinha-pequena-de-casa & Pygochelidon cyanoleuca & - \\
\hline 213 & Andorinha-do-campo & Progne tapera & - \\
\hline 214 & Andorinha-doméstica-grande & Progne chalybea & - \\
\hline 215 & Andorinha-serrador & Stelgidopteryx ruficollis & - \\
\hline 216 & Andorinha-de-sobre-branco & Tachycineta leucocorrhoba & - \\
\hline 217 & Gralha-do-campo & Cyanocorax cristatellus & - \\
\hline 218 & Cancã & Cyanocorax cyanopogon & - \\
\hline 219 & Corruíra & Troglodytes musculus & - \\
\hline 220 & Sabiá-una & Platycichla flavipes & - \\
\hline 221 & Sabiá-coleira & Turdus albicollis & - \\
\hline 222 & Sabiá-poca & Turdus amaurochalinus & - \\
\hline 223 & Sabiá-da-mata & Tudus fumigatus & - \\
\hline 224 & Sabiá-barranco & Turdus leucomelas & - \\
\hline 225 & Sabiá-laranjeira & Turdus rufiventris & - \\
\hline 226 & Sabiá-ferreiro & Turdus subalaris & - \\
\hline 227 & Sabiá-do-campo & Mimus saturninus & - \\
\hline 228 & Caminheiro-zumbidor & Anthus lutescens & - \\
\hline 229 & Pitiguari & Cyclarhis gujanensis & - \\
\hline 230 & Verdinho-coroado & Hylophilus poicilotis & - \\
\hline 231 & Juruviara-norte-americano & Vireo olivaceus & - \\
\hline 232 & Pula-pula & Basileuterus culicivorus & - \\
\hline 233 & Pula-pula-assobiador & Basileuterus leucoblepharus & - \\
\hline 234 & Pia-cobra & Geothlypis aequinoctialis & - \\
\hline 235 & Mariquita & Parula pitiayumi & - \\
\hline
\end{tabular}




\begin{tabular}{|c|c|c|c|}
\hline 236 & Cambacica & Coereba flaveola & - \\
\hline 237 & Bonito-do-campo & Chlorophonia cyanea & - \\
\hline 238 & Figuinha-de-rabo-castanho & Canirostrum speciosum & - \\
\hline 239 & Saí-azul & Dacnis cayana & - \\
\hline 240 & Fi-fi-verdadeiro & Euphonia chlorotica & - \\
\hline 241 & Gaturamo-rei & Euphonia cyanocephala & - \\
\hline 242 & Ferro-velho & Euphonia pectoralis & - \\
\hline 243 & Gaturamo-verdadeiro & Euphonia violácea & - \\
\hline 244 & Saíra-de-papo-preto & Hemithraupis guira & - \\
\hline 245 & Saíra-da-mata & Hemithraupis ruficapilla & - \\
\hline 246 & Sanhaço-pardo & Orchesticus abeillei & - \\
\hline 247 & Viúva & Pipraeidea melanonota & - \\
\hline 248 & Sanhaço-de-fogo & Piranga flava & - \\
\hline 249 & Tiê-sangue & Ramphocelus bresilius & - \\
\hline 250 & Bico-de-veludo & Schistochlamys ruficapillus & - \\
\hline 251 & Sanhaço-frade & Stephanophorus diadematus & - \\
\hline 252 & Tiê-preto & Tachyphonus coronatus & - \\
\hline 253 & Tiê-galo & Tachyphonus cristatus & - \\
\hline 254 & Saíra-amarela & Tangara cayana & - \\
\hline 255 & Saíra-lagarta & Tangara desmaresti & - \\
\hline 256 & Saíra-preciosa & Tangara preciosa & Anexo II \\
\hline 257 & Sete-cores & Tangara seledon & - \\
\hline 258 & Saí-andorinha & Tersina viridis & - \\
\hline 259 & Canário-sapé & Thlypopsis sordida & - \\
\hline 260 & Sanhaço-de-encontro-amarelo & Thraupis ornata & - \\
\hline 261 & Sanhaço-do-coqueiro & Thraupis palmarum & - \\
\hline 262 & Sanhaço-cinzento & Thraupis sayaca & - \\
\hline 263 & Tiê-de-topete & Trichothraupis melanops & - \\
\hline 264 & Tico-tico-do-campo-verdadeiro & Ammodramus humeralis & - \\
\hline
\end{tabular}




\begin{tabular}{|c|l|l|c|}
\hline 265 & Cigarra-bambu & Haplospiza unicolor & - \\
\hline 266 & Curió & Oryzoborus angolensis & Anexo I-VU \\
\hline 267 & Cardeal & Paroaria coronata & - \\
\hline 268 & Galo-da-campina & Paroaria dominicana & - \\
\hline 269 & Canário-da-terra-verdadeiro & Sicalis flaveola & - \\
\hline 270 & Coleirinho & Sporophila caerulescens & - \\
\hline 271 & Bigodinho & Sporophila lineola & - \\
\hline 272 & Tziu & Volatinia jacarina & - \\
\hline 273 & Tico-tico & Zonotrichia capensis & - \\
\hline 274 & Trinca-ferro-verdadeiro & Saltator similis & - \\
\hline 275 & Garibaldi & Agelaius ruficapillus & - \\
\hline 276 & Soldado & Cacicus chrysopterus & - \\
\hline 277 & Melro & Gnorimopsar chopi & - \\
\hline 278 & Inhapin & Icterus cayanensis & - \\
\hline 279 & Corrupião & Icterus jamacaii croconotus & - \\
\hline 280 & Chopim & Molothrus banariensis & - \\
\hline 281 & Chopim-do-brejo & Pseudoleistes guirahuro & - \\
\hline 282 & Polícia-inglesa & Sturnella superciliaris & - \\
\hline 283 & Pintassilgo & Carduelis magellanica & Passer domesticus \\
\hline 284 & Pardal & Estrilda astrild & - \\
\hline 285 & Bico-de-lacre & \\
\hline
\end{tabular}

\section{CASSE MAMMALIA}

\begin{tabular}{|c|l|l|c|}
\hline $\mathbf{N}^{\mathbf{0}}$ & NOME POPULAR & NOME CIENTÍFICO & AMEAÇA \\
\hline 01 & Cuíca & Caluromys philander & - \\
\hline 02 & Gambá-de-relha-branca & Didelphis albiventris & - \\
\hline 03 & Gambá-de-orelha-preta & Didelphis aurita & - \\
\hline 04 & Cuíca & Gracilinanus microtarsus & Anexo II \\
\hline
\end{tabular}




\begin{tabular}{|c|c|c|c|}
\hline 05 & Cuíca-de-cauda-grossa & Lutreolina crassicaudata & - \\
\hline 06 & Cuíca & Marmosa cinérea & - \\
\hline 07 & Cuíca & Marmosops paulensis & Anexo II \\
\hline 08 & Catita & Manodelphis americana & - \\
\hline 09 & Catita & Monodelphis iheringi & Anexo II \\
\hline 10 & Catita & Monodelphis sorex & - \\
\hline 11 & Cuíca-de-quatro-olhos & Philander frenatus & - \\
\hline 12 & Preguiça-de-três-dedos & Bradypus variegatus & - \\
\hline 13 & Tatu-galinha & Dasypus novemcinctus & - \\
\hline 14 & Tatu-peba & Euphractus sexcinctus & - \\
\hline 15 & Sagüi-de-tufo-branco & Callithrix jacchus & - \\
\hline 16 & Sagüi-de-tufo-preto & Callithrix penicillata & Anexo I-VU \\
\hline 17 & Macaco-prego & Cebus nigritus & - \\
\hline 18 & Macaco-sahui-guaçu & Callicebus nigrifrons & Anexo I-VU \\
\hline 19 & Bugio & Alouatta guariba clamitans & Anexo I-VU \\
\hline 20 & Morcego-hematófago & Desmodus rotundus & - \\
\hline 21 & Morcego-beija-flor & Glossophaga soricina & - \\
\hline 22 & $\begin{array}{l}\text { Morcego-das-listras-brancas-na- } \\
\text { cabeça }\end{array}$ & Artibeus lituratus & - \\
\hline 23 & $\begin{array}{l}\text { Morcego-das-listras-brancas-na- } \\
\text { cabeça-e-nas-costas }\end{array}$ & Platyrrhinus lineatus & - \\
\hline 24 & Morcego-ipanema & Pygoderma bilabiatum & - \\
\hline 25 & Morcego-do-ombro-amarelo & Sturnira lilium & - \\
\hline 26 & $\begin{array}{l}\text { Morcego-de-cauda-livre- } \\
\text { aveludada }\end{array}$ & Molossus molossus & - \\
\hline 27 & Morcego-de-cara-de-cachorro & Molossus temminckii & - \\
\hline 28 & Morcego-de-cauda-livre & Nyctinomops laticaudatus & - \\
\hline 29 & Morcego-de-cauda-livre & Tadarida brasiliensis & - \\
\hline 30 & Morcego-de-orelhas-grandes & Histiotus velatus & - \\
\hline
\end{tabular}




\begin{tabular}{|c|c|c|c|}
\hline 31 & Morcego-grisalho & Lasiurus cinereus & - \\
\hline 32 & Morcego-de-rabo-cabeludo & Lasiurus ega & - \\
\hline 33 & Pequeno-morcego-marrom & Myotis nigricans & - \\
\hline 34 & Cachorro-do-mato & Cerdocyon thous & - \\
\hline 35 & Gato-do-mato & Leopardus tigrinus & Anexo I-VU \\
\hline 36 & Onça-parda & Puma concolor capricornensis & Anexo I-VU \\
\hline 37 & Gato-mourisco & Puma yagouaroundi & Anexo II \\
\hline 38 & Lontra & Lontra longicaudis & Anexo I-VU \\
\hline 39 & Irara & Eira bárbara & - \\
\hline 40 & Furão & Galictis cuja & - \\
\hline 41 & Quati & Nasua nasua & - \\
\hline 42 & Mão-pelada & Procyon cancrivorus & Anexo II \\
\hline 43 & Anta & Tapirus terrestris & Anexo I-EP \\
\hline 44 & Veado-catingueiro & Mazama gouazoubira & - \\
\hline 45 & Caxinguelê & Sciurus ingrami & - \\
\hline 46 & Ratazana & Rattus norvegicus & - \\
\hline 47 & Rato-doméstico & Rattus rattus & - \\
\hline 48 & Rato-silvestre & Akodon sp & - \\
\hline 49 & Rato-silvestre & Oligoryzomys nigripes & - \\
\hline 50 & Rato-silvestre & Oryrzomys ratticeps & - \\
\hline 51 & Rato-silvestre & Oxymycterus quaestor & - \\
\hline 52 & Rato-silvestre & Oxymycterus rufus & - \\
\hline 53 & Ouriço-cacheiro & Sphiggurus villosus & - \\
\hline 54 & Preá & Cavia fulgida & - \\
\hline 55 & Capivara & Hydrochoeris hidrochaeris & - \\
\hline 56 & Paca & Cuniculus paca & Anexo I-VU \\
\hline 57 & Ratão-do-banhado & Myocastor coypus & - \\
\hline 58 & Tapiti & Sylvilagus brasiliensis & - \\
\hline
\end{tabular}


Anexo 6 - Primeira página do Currículo Lattes da autora, retirada da Plataforma Lattes, em cumprimento a Portaria/CPG/03/08.

Currículo do Sistema de Currículos Lattes (Angela Maria Branco)

Página 1 de 15

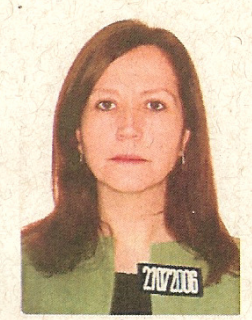

\section{Angela Maria Branco}

Possui graduação em Medicina Veterinária pela Universidade de São Paulo (1982) Especializacão em Saude Publica (1994) \& Especializacăo em Gestão Ambiental (1998) pela Faculdade de Saúde Publica da USP. Atuaimente é Médica Veterinária, Assessora Técnica da Secretaria Municioal do Vorde e do Meio Ambiente da Prefeitura de Sao Paulo; Conselheira da Pró-Animal - Uniao pela conscrentzaçao Ambrental e Preservaçao da vida. Tem expentencia na area de Controle de Zoonoses; Medicina da Conservap̧äo; imolantação de Centros de Manelo de Animais Silvestres: Alualmente desenvolve trabalhos nas áreas de Proteção de Mananciais (restauração ambiental) Biodiversidade

(Texto informado pelo autor)

Útima atualização do curriculo em 30/07/2008 Endereço para acessar este CV

Dados pessoais

Nome Angela Maria Branco

Nome em citaçóes BRANCO, Angela Maria bibliográficas

Sexo Feminino

Endereco profissional Prefeitura Municipal de São Paulo Pua do Paraiso, 387 Paraiso

04103-000-Sao Paulo, SP - Brasil

Telefone: (11) 33963000 Ramal: 3030

URL da Homepage: http://prefeiturasp.gov.br

Endereço eletrônico

angelabrancossuol combr

Formação acadêmica/Titulação

2006 Mestrado em Saude Publica

FACULDADE DE SAÚDE PUBBLICA -UNIVERSIDADE DE SÃO, FSP, BIaSI

Titulo: Polfficas Públicas e Serviços Públicos de Gestão e Manejo da Fauna Sivestre Nativa Resgatada. Es

Cáso: Prefelura da Cidade de São Paulo, Orientador. Helena Ribeiro.

1997 - 1998 Especializacao en Gestao Ambiental (Carga Horária: 476h)

Unversidade de São Paulo, USP. Bras!

Titulo: Plano de Gestao Ambrental para Areas de Protecão aos Mananciais-Estudo de Caso da Estrada de Distrito de Engenhelro Marsilac, São Paulo - S.A.

Orientador, Valdr, Akihiko Nakazawa.

1994 - 1994 Especializaça em Saude Publica. (Carga Horánia: 420h)

Universidade de São Paulo, USP, Brasil

Titulo: Programa de Atenção à Muther: Em Defesa da Vida e da Cidadania.

Orientador: Ana Maria Galuzzi

1978 - 1982 Graduaçäo em Medicha Veterinária. Universidade de São Paulo, USP Brasil.

Formação complementar

2007-2007 Curso Pericia Judicial Ambiental. (Carga horania: 20h).

2004-2004 Extensão universitária em lO A Conservaçăo Clinica e Manejo de Animais Silv. (Carga horária: 4h). Socjedade Brasileira de Medicina Veternária, SBMV, Bras!

1997 - 1997 Extensa universitaria em Abordagem Administrativa e Area de Recursos Humano. (Carca horária: 64h) 